\begin{tabular}{|l|l|}
\hline 2. To: (Receiving Organization) & 3. From: (Originating Organization) \\
Plutonium Finishing Plant & Criticality and Shielding \\
\hline 5. Proj./Prog./Dept./Div.: & 6. Design Authority/ Design Agent/Cog. \\
PFP & W. D. Wittekind \\
\hline
\end{tabular}

8. Originator Remarks:

Transmittal of CSER 96-023 for PFP glovebox HC-21A with 4.4 kilogram plutonium cans

11. Receiver Remarks: 11A. Design Basel ine Document? [] Yes [X] No

4. Related EDT No.:

619222

7. Purchase Order No.:

N/A

9. Equip./Component No.: $\mathrm{N} / \mathrm{A}$

10. System/Bldg./Facility: 234-5Z, PFP

12. Major Assm. Dwg. No.: $N / A$

13. Permit/Permit Apolication No.: $N / A$

14. Required Response Date: $N / A$

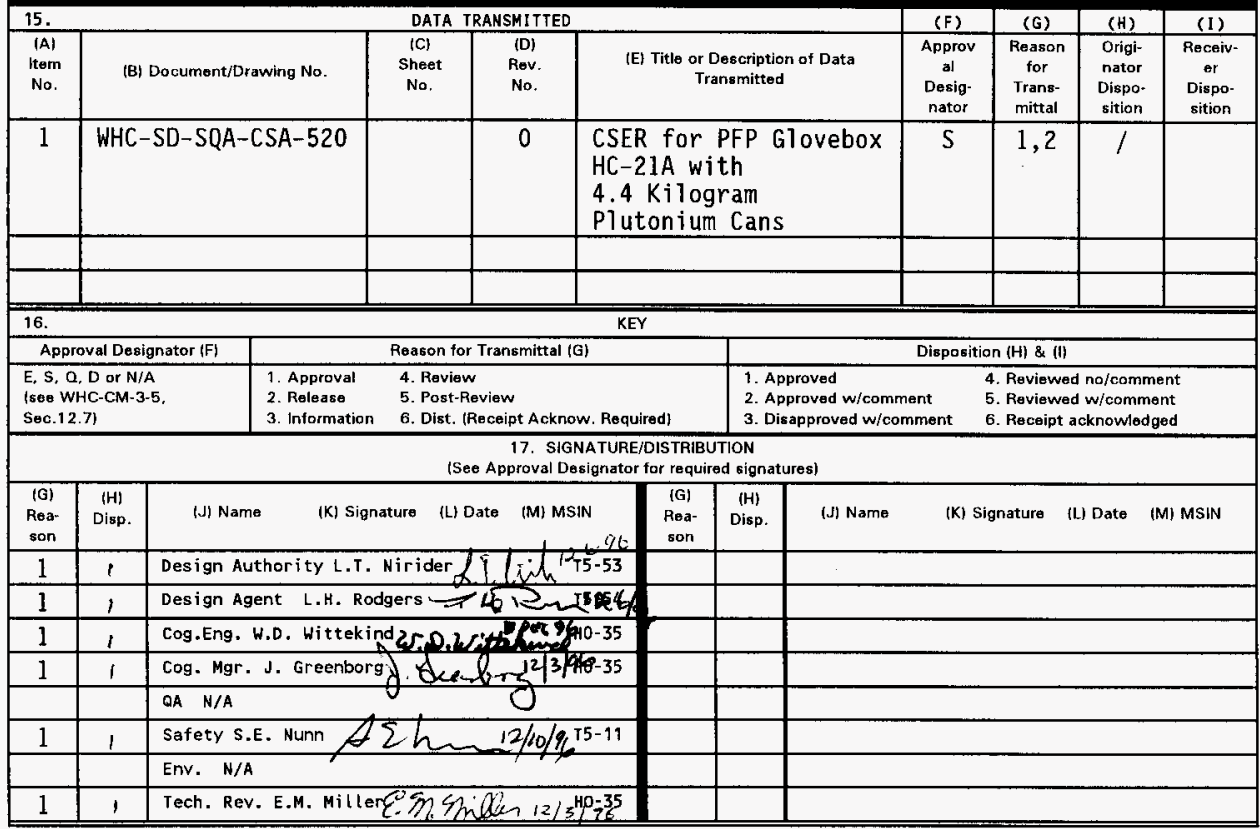

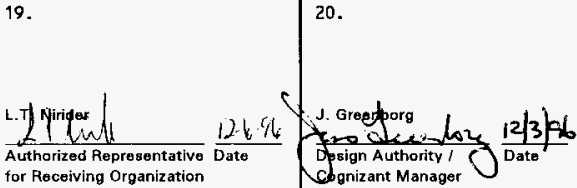

19. for Receiving Organization
21. DOE APPROVAL (if requi red) Ctrl. No.

[] Approved

[] Approved w/comments

[] D isapproved $w /$ comments 


\section{CSER 96-023: CSER for PFP Glovebox HC-21A with 4.4 Kilogram Plutonium Cans}

Warren D. Wittekind

Fluor Daniel Northwest, Richland, WA 99352

U.S. Department of Energy Contract DE-ACOG-O7AL-10930-DE-AC06-96RL13200

EDT/ECN: 619222

Org Code: 403

B\&R Code: EW7003000

UC: 507

Charge Code: $K 6058$

Tota1 Pages: $62^{2}-73$

Key Words: Glovebox HC-21A, Criticality, PFP

Abstract: This criticality safety evaluation report addresses the criticality impact of increasing plutonium oxide content from $2.5 \mathrm{~kg}$ oxide storage cans to $5.0 \mathrm{~kg}$ oxide Pu storage cans. Glovebox HC-21A is used to move plutonium metal buttons from cans into furnace boats prior to transferring them to the muffle furnace gloveboxes. Glovebox HC-21A supports muffle furnace operations where plutonium buttons are burned to form $\mathrm{PuO}_{2}(\mathrm{H} / \mathrm{Pu}<2)$. The $\mathrm{PuO}_{2}$ is returned to glovebox $\mathrm{HC}-21 \mathrm{~A}$ and sieved and packed into the $4.4 \mathrm{~kg}$ Pu cans.

The plutonium mass limit is set at $7.5 \mathrm{~kg}$ plutonium when plutonium metal is present. The plutonium mass limit is set at 15 . $\mathrm{kg}$ plutonium when no plutonium metal is present. Additionally, there are other requirements to assure criticality safety during this operation.

TRADEMARK DISCLAIMER. Reference herein to any specific comercial product, process, or service by trade name, trademark, manufacturer, or otherwise, does not necessarily constitute or imply its endorsement, recommendation, or favoring by the United States Government or any agency thereof or its contractors or subcontractors.

Printed in the United States of America. To obtain copies of this document, contact: WHC/BCS Document Control Services, P.0. Box 1970, Mailstop H6-08, Richland WA 99352, Phone (509) 372-2420; Fax (509) 376-4989.

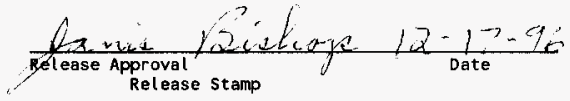

Approved for Public Release 
WHC-SD-SQA-CSA-520 Rev. 0

\section{CSER FOR PFP GLOVEBOX HC-21A WITH 4.4 KILOGRAM PLUTONIUM CANS}


WHC-SD-SQA-CSA-520 Rev. 0

\author{
CONTENTS
}

1.0 INTRODUCTION AND SUMMARY . . . . . . . . . . . . . . . . . . . . . . . . 1

2.0 SUMMARY AND CONCLUSIONS . . . . . . . . . . . . .... 2

3.0 DESIGN FEATURES AND ADMINISTRATIVELY CONTROLLED LIMITS AND

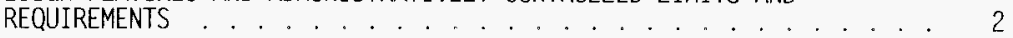

4.0 DESCRIPTION OF SYSTEM AND FACILITY . . . . ........ 4

4.1 PROCESS FLOW DESCRIPTION $\ldots$

4.1.1 Preparation of Plutonium for Furnace Burning . . 4

4.1.2 Transfer of Plutonium Oxide into 4.4 Kilogram Cans: 5

4.1.3 Sealing of Plutonium 0xide in 4.4 Kilogram Cans. . 5

4.2 GLOVEBOX HC-21A DESCRIPTION . . . . . . . . . . . 5

4.3 GLOVEBOX EQUIPMENT AND ALLOWED CONTAINERS $\ldots$

5.0 REVIEW OF STABILIZATION OPERATIONS AND CONTROLS . . . . . . . . . 9

5.1 PREVIOUS EQUIPMENT AND LIMITS FOR GLOVEBOX HC-21A $\ldots . . .9$

5.2 INCENTIVES FOR REVISED LIMITS

5.3 NEW CRITICALITY LIMITS LOGIC, RATIONALE, AND JUSTIFICATION : 11

6.0 BASIC CRITICAL PARAMETERS FOR PU FORM AND CONTENT . . . . . . 12

6.1 SPHERICAL GEOMETRY CORRELATIONS . . . . . . . . . . . 12

6.1.1 Dry Plutonium Oxide . . . . . . . . . . . . . . . . . . . . . 13

6.1 .2 Wet Plutonium Oxide . . . . . . . . . . . . . . . . 13

6.2 SLAB GEOMETRY CORRELATIONS $\ldots \ldots . \cdots$

6.2.1 Nominally Reflected Siab . . . . . . . . . . . 16

6.2.2 Slab with Full Reflection Above or Below . . . . 18

6.2.3 Fully Reflected Slab . . . . . . . . . . . . . . 18

7.0 MONK6B MONTE-CARLO GLOVEBOX MODELING . . . . . . . . . . . . . . 19

7.1 METHODS VALIDATION

7.2 MODEL ING ASSUMPTIONS WITH PLUTONIUM METAL BUTTONS $\ldots$

$\begin{array}{ll}\text { 7.2.1 Plutonium Metal in HC-21A Normal and Off-Normal } & 19 \\ \text { Conditions }\end{array}$

7.2.2 Plutonium Metal in Parametric Study Calculations . . 20

7.3 MODELING ASSUMPTIONS WITH 4.4 KILOGRAM PLUTONIUM CANS ... 20

8.0 DISCUSSION OF CONTINGENCIES ................ . . . 21

8.1 GLOVEBOX MASS LIMIT EXCEEDEDD $\ldots$

8.22 .5 KG PLUTONIUM METAL MASS CONTAINER LIMIT EXCEEEEED $\cdots \cdots$

$8.3 \quad 6.0 \mathrm{KG}$ PU IN PUO, MASS CONTAINER LIMIT EXCEEDED $\ldots \ldots \ldots$

8.4 FILLED 4.4 KG PU ${ }^{2}$ CAN NUMBER LIMIT EXCEEDED . . . . . . . . . . . . . 23

8.5 CONTAINER VOLUME LIMIT EXCEEDED

8.6 STACKING OF PLUTONIUM BEARING CONTAINERS $\ldots \ldots$

8.7 TRANSPORT WAGON UNDERNEATH GLOVEBOX $\ldots . . \cdots 24$

$8.8 \mathrm{H} / \mathrm{PL}>2$ MATERIAL INSIDE GLOVEBOX $\ldots \ldots \ldots$

8.9 CONTAINER CLUSTER INTERACTION $\ldots \ldots$

8.10 INTRODUCTION OF WATER INTO GLOVEBOX $\ldots . \cdots$

8.11 WATER INGRESS DUE TO FIRE . . . . . . . . . . . . . . . . 25

8.12 SEISMIC CONCERNS $\ldots \ldots \ldots$ 
WHC-SD-SQA-CSA-520 Rev. 0

9.0 EVALUATION AND RESULTS . . . . . . . . . . . . . . . . . . . 25

9.1 NORMAL CONDITIONS . . . . . . . . . . 26

9.1.1 Preparation of Plutonium for Furnace Burning . . . 26

9.1.2 Transfer of Plutonium 0xide into 4.4 Kilogram Cans . . 28

9.1.3 Sealing of Plutonium Oxide in 4.4 Kilogram Cans. . 28

9.2 OFF-NORMAL CONDITIONS . . . . . . . . . . . . . . . . . . . . . 29

9.2.1 Glovebox Mass Limit Exceeded . . . . . . . . . . . 29

$9.2 .22 .5 \mathrm{~kg}$ Plutonium Metal Mass Container Limit Exceeded. 29

$9.2 .36 .0 \mathrm{~kg}$ Pu in PuO $\mathrm{Puss}_{2}$ Mantainer Limit Exceeded .. 30

9.2.4 Filled $4.4 \mathrm{~kg} \mathrm{Pu}$ Can Number Limit Exceeded . . . . . . . 31

9.2 .5 Container Volume Limit Exceeded . . . . . . . . 31

9.2.6 Stacking of Plutonium Bearing Containers . . . . . . . 31

9.2 .7 Transport Wagon Underneath GTovebox . . . . . . . 32

9.2.8 H/Pu>2 Material Inside Glovebox .... . . . . . . . 32

9.2 .9 Container Cluster Interaction . . . . . . . . 32

9.2.10 Introduction of Water into Glovebox . . . . . . . . . 33

9.2.11 Water Ingress Due to Fire . . . . . . . . . . . 33

9.2.12 Seismic Concerns . . . . . . . . 34

9.3 PARAMETRIC STUDY OF PLUTONIUM METAL WITH PLUTONIUM OXIDE $\ldots 35$

10.0 REFERENCES . . . . . . . . . . . . . . . . . . . . . . . . 38

\section{APPENDICES}

APPENDIX A

INDEPENDENT REVIEW COMMENTS AND CHECKLIST . . . . . . . . . . . . . A-1

APPENDIX B

MONK COMPUTER CODE VALIDATION . . . . . . . . . . . . . . . . . . B-1

APPENDIX C

REPRESENTATIVE MONK6B INPUT FILES . . . . . . . . . . . . . . . . c c-1

APPENDIX D

PARAMETRIC STUDY SPREADSHEET FILES ................ . . . . . . . . .

APPENDIX E

MONK6B CASE DESIGNATION AND SUMMARY . . . . . . . . . . . . . . E E-1

LIST OF FIGURES

Figure 1. Room Configurations for Stabilization Program at PFP. . . . . 6

Figure 2. Glovebox HC-21A Layout for Muffle Furnace Operation Support : 7 


\section{WHC-SD-SQA-CSA-520 Rev. 0}

\section{LIST OF TABLES}

Table 4.1 Can Dimensions. . . . . . . . . . . . . . . . . . 239. . . 8

Table 6.1. Criticality Parameters for Spherical Configurations, ${ }^{239} \mathrm{PuO}_{2}$ Water Mixes . . P.............. 14

Table 6.2 . Criticality Parameters for siab Geometry Configurations of ${ }_{239}^{\circ}$ Pu-water Mixes . . . . . . . 17

Table 9.1 HC-21A Normal and Off-Normai MONK6B Results. . . . 27

Table 9.2 Plutonium Metal and Plutonium Oxide MONK6B Results. . . . . . 35

Table 9.3 Three Button Plutonium Metal Stack MONK6B Results. . . . . . . 37

Table 9.4 15.0 Kilogram Plutonium Oxide Cylinder MONK6B Results. . . . . 37

Table D.1 0 Plutonium Button Calculation for Radius, Height . . . D-3

Table 0.2 1 Plutonium Button Calculation for Radius. Height . . . . . . D-4

Table D.3 2 Plutonium Button Calculation for Radius, Height . . . . . . D-4

Table 0.4 3 Plutonium Button Calculation for Radius, Height . . . . . . D-5

Table D.5 4 Plutonium Button Calculation for Radius, Height . . . . . . D-5

Table E.1 HC-21A Furnace Boat MONK6B Results. . . . . . . . . . . . E-3

Table E.2 HC-21A Sieve Screen Pan MONK6B Results. . . . . . . . . . . . E-3

Table E.3 HC-21A $4.4 \mathrm{~kg}$ Pu Cans MONK6B Results. . . . . . . E-4

Table E.4 Parametric Study of Pu and Pu0 ${ }_{2}$ MONK6B Results. . . . . . . E-5 
WHC-SD-SQA-CSA-520 Rev. 0

CSER-96-023

Titie: CSER 96-023: PFP Glovebox HC-21A with 4.4 kilogram Plutonium Cans
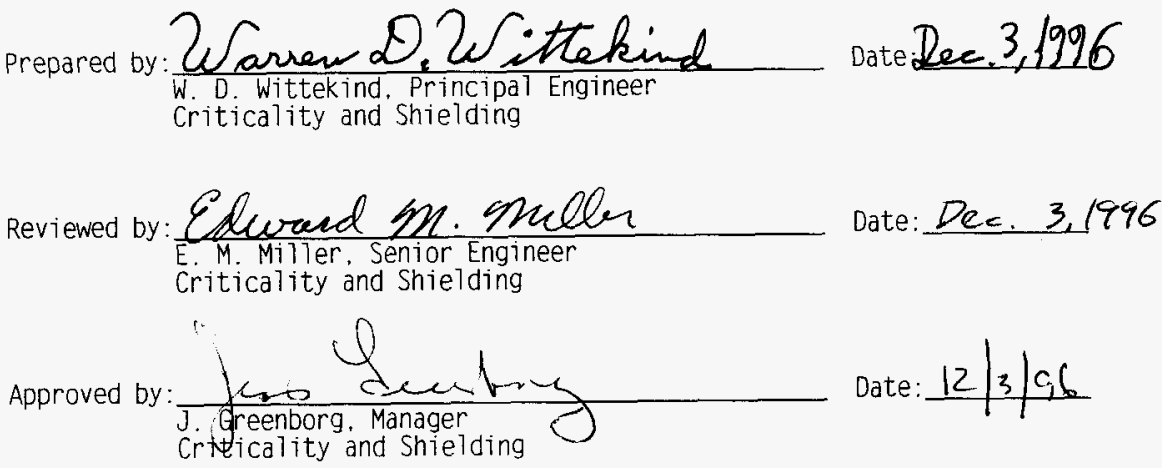

vi 


\section{WHC-SD-SQA-CSA-520 Rev. 0}

This page intentionally left blank 
WHC-SD-SQA-CSA-520 Rev. 0

\section{CRITICALITY SAFETY EVALUATION REPORT 96-023: PFP GLOVEBOX HC-21A WITH 4.4 KILOGRAM PLUTONIUM CANS}

\subsection{INTRODUCTION AND SUMMARY}

This nuclear criticality safety analysis has been performed to increase the approved plutonium mass limit for individual containers in the $\mathrm{HC}-21 \mathrm{~A}$ glovebox. This glovebox was approved to hold up to $5 \mathrm{~kg}$ of plutonium and only one (1) plutonium metal button of up to $2.5 \mathrm{~kg}$ of plutonium metal. The purpose of this CSER is to increase the limit to support operations in burning plutonium metal buttons, preparing plutonium oxide mixed with other materials including moderators for drying and storage of $4.4 \mathrm{~kg}$ of plutonium in $5 \mathrm{~kg}$ of dried $\mathrm{PuO}_{2}$ into each individual can.

The HC-21A glovebox supports muffle furnace operations. The muffle furnace burns plutonium metal buttons producing dry $\mathrm{PuO},(\mathrm{H} / \mathrm{Pu}<2)$. Metal buttons and other plutonium material enter the HC-21A glovebox in containers and cans and are placed in Hastelloy-X boats in preparation for transfer to a muffle furnace glovebox. After being heated in a muffle furnace, the plutonium product, largely $\mathrm{PuO}_{2}$, is transferred back to glovebox $\mathrm{HC}-21 \mathrm{~A}$ in a boat. The dry $\mathrm{PuO}_{2}$ product is sieved and $\left.4.4 \mathrm{~kg} \mathrm{Pu}(5.0 \mathrm{~kg} \mathrm{PuO})_{2}\right)$ is placed in a can. The $\mathrm{PuO}_{2}$ from the muffle furnace is checked for $\mathrm{H} / \mathrm{Pu}$ content, and if acceptable, the can is sealed. This can, a convenience can, is then placed inside an inner can, which is also sealed. The doubly canned $\mathrm{PuO}_{2}$ is then bagged out of glovebox HC-21A for further operation and storage. Eventually, the $\mathrm{PuO}_{2}$ is quadruple canned, with each can being sealed. Each of the cans may or may not be normal food pack cans, and all have lids on them.

The normal and off-normal conditions for the glovebox HC-21A considered two different and parallel operations: (1) plutonium metal buttons or plutonium material from cleanout activities (usually limited in quantity, but with an undetermined moisture content) is placed into furnace boats to transfer to a muffle furnace glovebox, and (2) $\mathrm{PuO}_{2}$ sieving and packing the product transferred from a muffle furnace into the 5.0 kilogram $\mathrm{PuO}_{2}$ (4.4 kilogram plutonium) food pack cans. The upset condition of plutonium metal buttons together with plutonium compounds was analyzed by performing parametric calculations of the reactivity of plutonium metal covered by plutonium compounds. The upset condition for dry $\mathrm{PuO}_{2}$ in cans was modeled explicitly by placing a number of cans together. Normal conditions were conservatively modeled by assuming the most reactive normal material composition (maximum normal moderation and density), and arranging cans in the glovebox in close proximity. Water ingress and mixing with uncanned $\mathrm{PuO}_{2}$ was reviewed for limits on mass and volume limits for aggregates of containers for each glovebox operation. 
Criticality safety is controlled by limiting the total mass in the glovebox and by limiting the total mass of plutonium metal in a container or by limiting the volume of a container carrying plutonium compound. The mass Timits for the entire $\mathrm{HC}-21 \mathrm{~A}$ glovebox are: (1) $7.5 \mathrm{~kg}$ of plutonium if plutonium metal is present; OR (2) $15 \mathrm{~kg}$ of plutonium if plutonium metal is not present. The accumulation in one container is 1 imited to $2.5 \mathrm{~kg}$ of metal. Each operation has a limitation on plutonium mass and volume limit for a container or group of containers holding plutonium in a compound such as $\mathrm{PuO}_{2}$. Plutonium operations using several containers have a 10 inch spacing requirement from other plutonium operations. No button, boat or container is to be stacked on top of any other fissile item. Other restrictions are a maximum of two filled $4.4 \mathrm{~kg}$ Pu containers in the glovebox, and a maximum of $6.0 \mathrm{~kg} \mathrm{Pu}\left(6.8 \mathrm{~kg} \mathrm{PuO}{ }_{2}\right)$ in a single container such as a sieve pan.

\subsection{SUMMARY AND CONCLUSIONS}

This criticality safety evaluation report (CSER) shows that the operations described in the process flow description and under the controls listed in the administratively controlled limits section is safe from a criticality stand point. No single identified contingency exceeded the criticality safety limit of $k_{\text {eff }}=0.9350$ or requires the mass or volume to more than double before a critical configuration is possible. Therefore this CSER meets the requirements for a criticality analysis of the Hanford Site Nuclear Criticality Safety Manual, WHC-CM-4-29.

\subsection{DESIGN FEATURES AND ADMINISTRATIVELY CONTROLLED LIMITS AND REQUIREMENTS}

Administratively controlled limits applicable to this evaluation are:

Plutonium metal present in glovebox:

1) When plutonium metal is present, glovebox maximum $7.5 \mathrm{~kg}$ plutonium.

2) A maximum of $2.5 \mathrm{~kg}$ plutonium meta 1 sha11 be placed in a furnace boat or other container.

Plutonium oxide operations, no plutonium metal present in glovebox:

3) When plutonium metal is not present, glovebox maximum $15.0 \mathrm{~kg}$ plutonium.

4) The following operations have limits of plutonium mass and volume of containers in each group spaced less that $25 \mathrm{~cm}(10 \mathrm{in.})$ apart.

4a) Pouring furnace boat $(\approx 2.2$ Liters) volume into sieve shaker system consisting of sieve pan and one sieve screen $(\approx 3.3$ Liters). No other plutonium container is allowed within 10 inches edge-to-edge from this container cluster. This operation is allowed a maximum unit volume of 6.0 Liters and $7.5 \mathrm{~kg} \mathrm{Pu}$. 
4b) Sieving operation composed of sieve shaker system consisting of sieve pan and one sieve screen ( $\approx 3.3$ Liters), and one mortar and pestle ( $\leq 1$ Liter), or one jaw crusher grinding system ( $\leq 1$ Liter). No other plutonium container is allowed within 10 inches edge-to-edge from this cluster of containers/equipment. This operation is allowed a maximum unit volume of 6.0 Liters and $7.5 \mathrm{~kg} \mathrm{Pu}$.

4c) Can filling operation consisting of sieve shaker pan without screen $(\approx 1.65$ Liters $)$ and one $4.4 \mathrm{~kg} \mathrm{Pu}$ can $(\approx 1.24$ Liters $)$. No other plutonium container is allowed within 10 inches edge-to-edge from this cluster of containers. This operation is allowed a maximum unit volume of 2.9 Liters and $7.5 \mathrm{~kg} \mathrm{Pu}$.

4d) Storing after a $4.4 \mathrm{~kg}$ Pu convenience can ( $\approx 1.24$ Liters $)$ without 1id is filled or sealing a lid on the convenience can. No other plutonium container is allowed within 10 inches edge-to-edge from this container. These operations are allowed a maximum unit volume of 1.5 Liters and $4.5 \mathrm{~kg} \mathrm{Pu}$.

4e) Storing lidded $4.4 \mathrm{~kg}$ Pu convenience cans ( $\approx 1.24$ Liters each) or inner cans $(\approx 1.42$ Liters each) and canning a lidded $4.4 \mathrm{~kg}$ Pu convenience can in an inner can. One sealed $4.4 \mathrm{~kg}$ Pu convenience can and one empty inner can may be adjacent for canning an inner can around the convenience can. Two sealed $4.4 \mathrm{~kg}$ Pu cans may be adjacent for storage or transferring out of the glovebox. No other plutonium container is allowed within 10 inches edge-to-edge from this cluster of two containers. This operation is allowed a maximum unit volume of 2.9 Liters and $9.0 \mathrm{~kg} \mathrm{Pu}$.

5) A maximum of $6.0 \mathrm{~kg}$ plutonium in a plutonium compound (this equals $6.8 \mathrm{~kg}$ of $\mathrm{PuO}_{2}$ ) shall be placed in a sieve shaker pan.

6) A maximum of $4.5 \mathrm{~kg}$ plutonium in a plutonium compound (this equals $5.1 \mathrm{~kg}$ of $\mathrm{PuO}_{2}$ ) shall be placed in a $4.4 \mathrm{~kg}$ Pu can.

7) A maximum of 2 filled $4.4 \mathrm{~kg}$ Pu size cans are allowed in the glovebox. If a $4.4 \mathrm{~kg}$ Pu can is filled to over half full, it is counted as filled.

8) A maximum 2.5 Liter container volume is allowed in glovebox HC-21A. Exception: Sieve system composed of one sieve catch pan with one sieve screen $(\approx 3.3$ Liters).

9) Only one sieve screen is allowed in the glovebox.

10) Do not stack plutonium bearing containers.

11) The pot sump in glovebox $\mathrm{HC}-21 \mathrm{~A}$ is sealed to exclude accumulation of fissile material in the pot sump.

12) During operation, a maximum of $1 / 8$ inch accumulation of solids is allowed on the glovebox floor. Spills are to be cleaned up prior to the next operation. 
WHC-SD-SQA-CSA-520 Rev. 0

13) DRY glovebox, meaning no flowing process liquids or liquids for fighting fire within this glovebox $(\mathrm{HC}-21 \mathrm{~A})$. Fire fighting category $\mathrm{C}$. This allows mists and fogs, but no directed solid streams of water.

These limits define an envelope of allowed masses, volumes, and spacings that have been analyzed as meeting criticality safety requirements. The criticality prevention specifications (CPS) for glovebox $\mathrm{HC}-21 \mathrm{~A}$ implementing these requirements can be more restrictive than the limits specified in this CSER.

The CPS does not have to repeat these requirements verbatim. Any requirement that is more restrictive, i.e. lower mass, smaller volume, fewer containers, or smaller aggregate volume of grouped containers, will have a larger margin of criticality safety and will meet the goal of ensuring a critically safe operation.

\subsection{DESCRIPTION OF SYSTEM AND FACILITY}

The 234-5Z Building more commonly referred to as PFP is located in the 200 west area. This facility was historically used to process plutonium into oxide or metal forms. The facility is now undergoing a cleanup phase to stabilize the plutonium still stored there.

\subsection{PROCESS FLOW DESCRIPTION}

Figure 1 iliustrates the layout of the area encompassing the Pu stabilization activities on the first floor of the PFP. Preparation of furnace boat charges is currently done in glovebox $\mathrm{HC}-21 \mathrm{~A}$ in Room 230B, as is also the handling of the product after firing in the furnaces. Loaded boats are transferred to the furnace gloveboxes ( $\mathrm{HC}-21 \mathrm{C}$ in Room 230A and HA-21I in Room 235B) via the conveyor gloveboxes $\mathrm{HC}-2, \mathrm{HC}-3, \mathrm{HC}-4$ and $\mathrm{HA}-28$. Thus, the furnace gloveboxes only receive prepared boats, and boats of fired material are output for transfer to other gloveboxes for further processing.

The gloveboxes involved in the processes for preparation, firing and product packaging for the furnace operations are designated as DRY gloveboxes, so that free water is not allowed (except for damp cleanup rags per Criticality Prevention Specifications [CPS] restrictions). There are no water or liquid lines for processes or fire fighting within the DRY gloveboxes.

\subsubsection{Preparation of Plutonium for Furnace Burning}

Material that will be received in glovebox $\mathrm{HC}-21 \mathrm{~A}$ in the near term wi11 be either a plutonium metal button $(<2.500 \mathrm{~g} \mathrm{Pu})$ or material from facility clean out activities. The amount of material from clean out activities will be small (typically $<1,000 \mathrm{~g}$ Pu per container). The primary feed source through early 1997 will be the plutonium metal buttons. The charges are made up in Hastelloy- $X$ furnace boats (approximately 2.2 Liters). One button will be placed in each boat. Up to five plutonium metal buttons will arrive in a transport wagon and be parked adjacent to the glovebox. 
One by one the plutonium metal buttons will be inserted into the glovebox through the sphincter port. Up to three furnace boat charges will be made up at a time. Three charges are sent to the three furnaces in glovebox $\mathrm{HA}-21 \mathrm{I}$ and two charges are sent to the two furnaces in glovebox $\mathrm{HC}-21 \mathrm{C}$. The boats are sent via conveyor $\mathrm{HC}-2$ to the muffle furnaces in $\mathrm{HC}-21 \mathrm{C}$, or via conveyor gloveboxes $\mathrm{HC}-2, \mathrm{HC}-3, \mathrm{HC}-4$ and $\mathrm{HA}-28$ to glovebox HA-21I.

\subsubsection{Transfer of Plutonium 0xide into 4.4 Kilogram Cans}

After the plutonium buttons are heated in the furnace for about 14 hours to about $1000^{\circ} \mathrm{C}$. the cooled furnace boats containing $\mathrm{PuO}_{2}$ and contaminants are sent back to $\mathrm{HC}-21 \mathrm{~A}$ via the conveyor system. At this time there won' $t$ be any plutonium in the form of metal in the glovebox, only $\mathrm{PuO}_{2}$. The boats now contain a very dry $\mathrm{PuO}_{2}$ powder. One at a time the boats are emptied into a pan sieve and sieved prior to placing in the $4.4 \mathrm{kilogram}$ plutonium container. It is expected that between 1 and 2 buttons will fit into one 4.4 kilogram plutonium container. There will be an effort to mix big buttons with smaller buttons where possible to get 2 whole buttons in a can. Once a can is filled. it is weighed. sampled for loss of weight on ignition (LOI) and transported to glovebox HC-18BS for temporary storage until the LOI results are returned.

Once all of the plutonium oxide cans are moved to HC-18BS, more metal buttons in cans or other containers will be inserted into glovebox $\mathrm{HC}-21 \mathrm{~A}$ through a sphincter port to make up more furnace boat charges for the muffle furnaces. Only a total of three buttons are to be brought into the $\mathrm{HC}-21 \mathrm{~A}$ glovebox at one time, although five buttons are normally brought to the glovebox by a five position transport wagon. The glovebox $\mathrm{HC}-18 \mathrm{BS}$ will be used for lag storage until the LOI results are available.

\subsubsection{Sealing of Plutonium Oxide in 4.4 Kilogram Cans}

Once the metal buttons are put in boats and moved out of $\mathrm{HA}-21 \mathrm{~A}$ and the LOI results are complete (4-8 hours) for the open $\mathrm{PuO}_{2}$ cans in $\mathrm{HC}-18 \mathrm{BS}$, the 4.4 kilogram Pu cans wi 11 be moved back to $\mathrm{HC}-21 \mathrm{~A}$ where the open can will be sealed with a can sealer, placed into a second can and sealed again prior to being sealed in a plastic bag and taken out of glovebox $\mathrm{HC}-21 \mathrm{~A}$.

Once outside the glovebox $\mathrm{HC}-21 \mathrm{~A}$, in another operation, each item wi11 be sealed in two more cans prior to transport via a transport wagon to vaults.

\subsection{GLOVEBOX HC-21A DESCRIPTION}

HC-21A is a conventional glovebox, 42 inches deep, 36 inches high, and 127 inches long supported 54 inches above the room floor by a table frame (WHC 1994a). Figure 2 is from the HC-21A layout drawing (WHC 1995a), and gives the floor plan arrangement for this glovebox. Note that this glovebox has gloveports on two sides. As shown in Figure 1 , the north end of $\mathrm{HC}-21 \mathrm{~A}$ connects to conveyor glovebox $\mathrm{HC}-2$. The connection to the $\mathrm{HC}-2$ conveyor acts as a criticality drain and eliminates the concern for glovebox holding water and flooding. The table frame supporting the $\mathrm{HC}-21 \mathrm{~A}$ glovebox has horizontal members (WHC 1994a) that preclude a transport wagon rolling underneath the glovebox from the front, the back or either end. 
Figure 1. Room Configurations for Stabilization Program at PFP

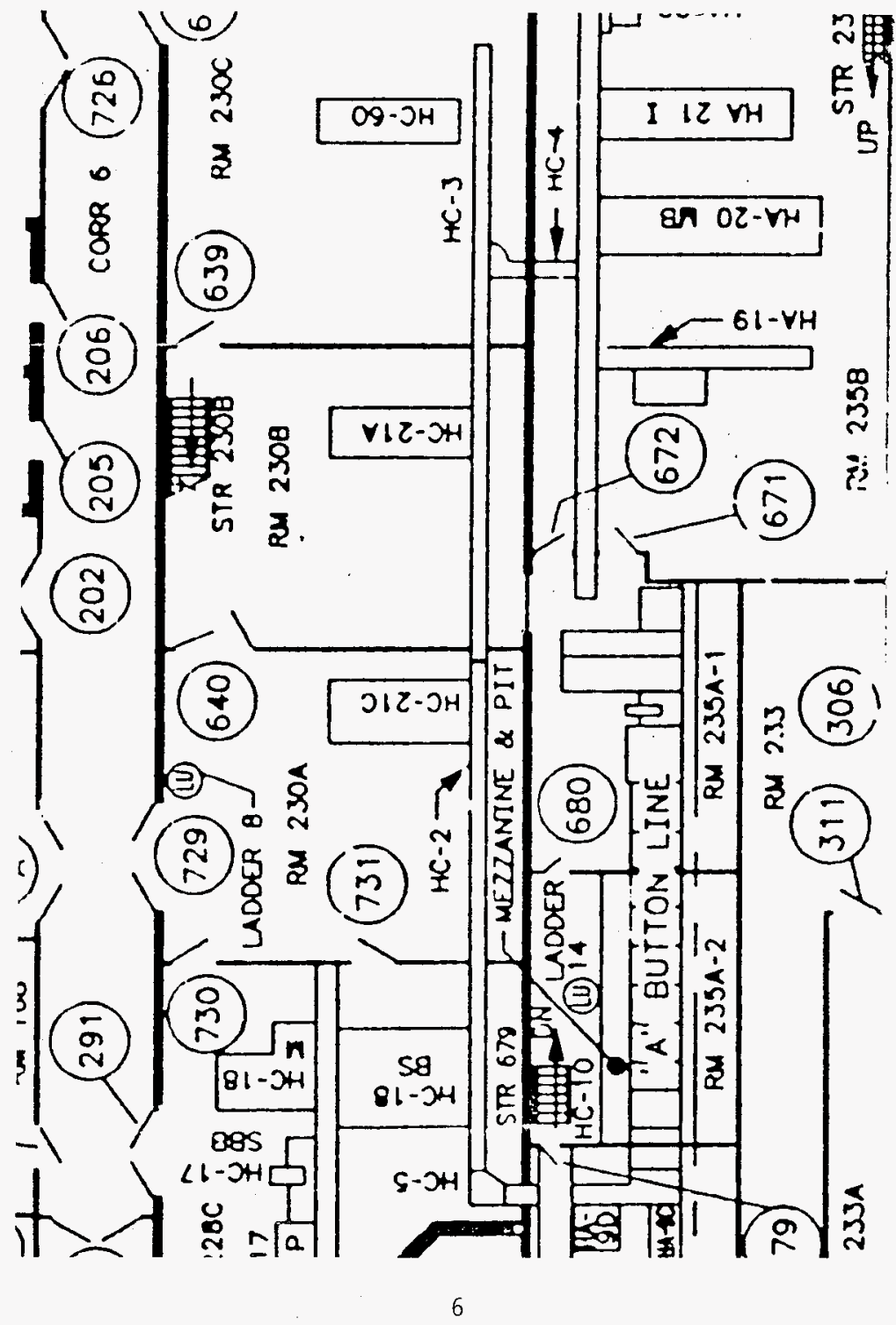


Figure 2. Glovebox HC-21A Layout for Muffle Furnace Operation Support

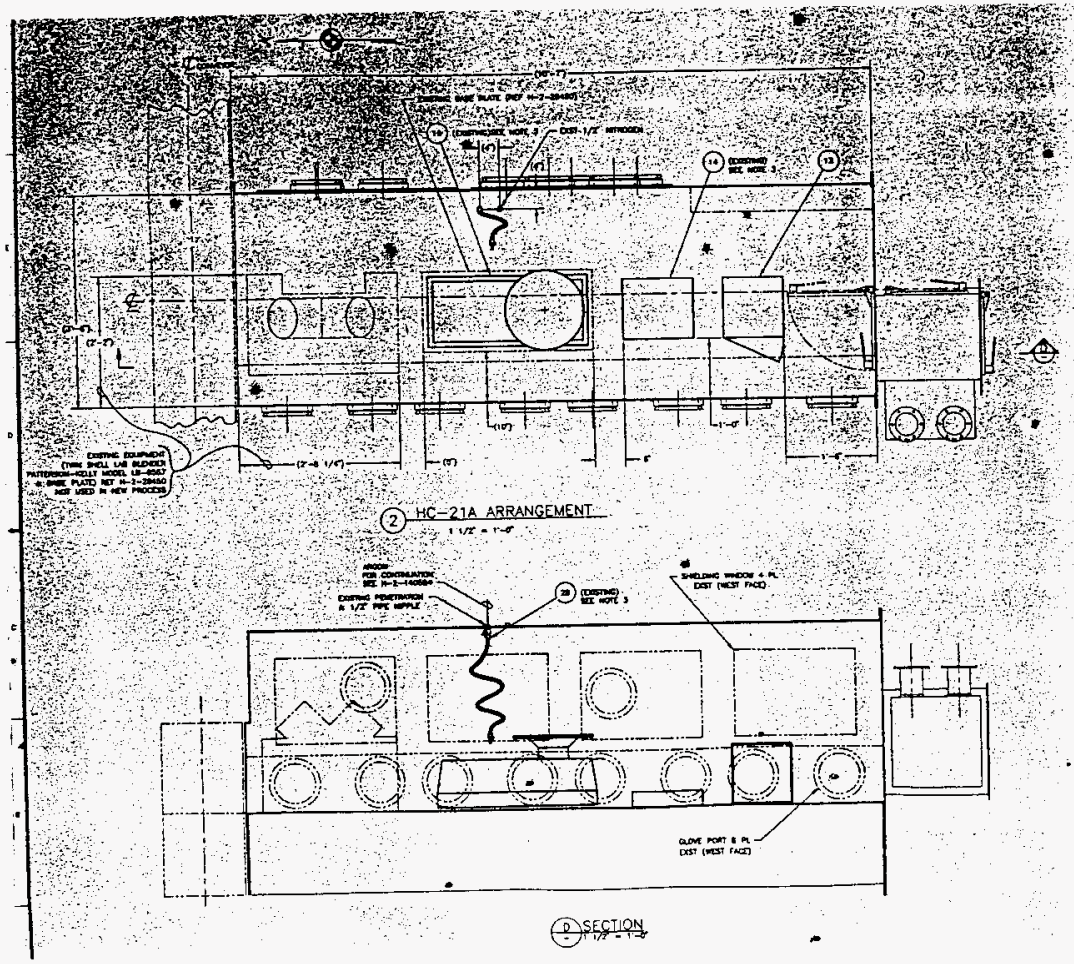


The north end of glovebox $\mathrm{HC}-21 \mathrm{~A}$ connects to the conveyor glovebox $\mathrm{HC}-2$ as shown in Figure 1 . The 8 -inch deep by 10 inch diameter pot-sump, under the box floor and near the south end of the box in Figure 2, will be sealed to exclude possible drainage of spilled materials into it.

\subsection{GLOVEBOX EQUIPMENT AND ALLOWED CONTAINERS}

The equipment available in glovebox HC-21A are:

- Canners (2).

- Electric can opener.

- Furnace boats (approximately 2.2 Liter volume),

- Grinder (approximately 1 Liter volume).

- Mortar and pestle (approximately 1 Liter volume).

- Scale.

- $\quad$ Sieve Shaker with one sieve pan and one sieve screen (3.3 Liters).

- Cans less than 2.5 Liter volume, and

- Other containers with less than 2.5 Liter volume.

The sieve shaker has the largest volume. The sieve shaker diameter is 8 in., and catch pan height and each sieve screen height is $5.08 \mathrm{~cm}(2$ in.). The volume is:

$$
\pi / 4 *(8 \text { in. })^{2} *(2 \text { in. }+1 * 2 \text { in. })=201 \text { in. }^{3} \Rightarrow 3.3 \text { Liters. }
$$

The furnace boat is made from $0.3175 \mathrm{~cm}$ (.125 in.) thick Hastelloy-X sheet stock shaped into a "cake pan", with an outside width of $13.34 \mathrm{~cm}$ $(5.25 \mathrm{in.}$ ) and an outside length of $28.58 \mathrm{~cm}$ (11.25 in.). Inside, the bottom of the pan has an area of $354.84 \mathrm{~cm}^{2}\left(5.0 \mathrm{in} . \times 11.0 \mathrm{in} .=55.0 \mathrm{in}^{2}=\right.$ $0.382 \mathrm{ft}^{2}$ ). A measured brim-fi11 volume of 2.2 iters equates to a inside brim height of $6.20 \mathrm{~cm}(2.44 \mathrm{in}$.).

The dimensions and volumes of the four cans to be nested to store the 4.4 kilograms of plutonium $\left(5.0\right.$ kilograms of $\left.\mathrm{PuO}_{2}\right)$ are shown in Table 4.1 . The inner can is slightly larger for double canning the innermost convenience can. The cans may or may not be standard food pack cans. They have a wal1 thickness of approximately $0.02286 \mathrm{~cm}(0.009$ inches $)$. Only the two innermost cans, the convenience can and the inner can, will be used in glovebox HC-21A. The dimensions of the four cans are listed in Table 4.1.

\begin{tabular}{|c|c|c|c|}
\hline \multicolumn{4}{|c|}{$\begin{array}{c}\text { Table 4.1 Can Dimensions. } \\
\text { Calculated Volume Assumed } \\
0.02286 \mathrm{~cm}(0.009 \text { in. }) \text { Wa11 Thickness }\end{array}$} \\
\hline Can & $00 \mathrm{~cm}$ (inch) & $\mathrm{H} \mathrm{cm}$ (inch) & Volume $(\mathrm{L})$ \\
\hline Convenience & $8.731(3.4375)$ & $20.955(8.250)$ & 2389 \\
\hline Inner & $9.208(3.6250)$ & $21.590(8.500)$ & 4203 \\
\hline Middle & $10.319(4.0625)$ & $22.860(9.000)$ & 8910 \\
\hline Outer & $10.795(4.2500)$ & $23.495(9.250)$ & 2.1280 \\
\hline
\end{tabular}




\subsection{REVIEW OF STABILIZATION OPERATIONS AND CONTROLS}

The operations of the muffle furnaces in glovebox $\mathrm{HC}-21 \mathrm{C}$ and recently added muffle furnaces in glovebox HA-21I and their support glovebox HC-21A as well as the storage glovebox HC-18BS are closely related and need to be described together. These gloveboxes are used for parts of a one continuing process and need to have consistent limits to avoid mistakes in handling the plutonium.

\subsection{PREVIOUS EQUIPMENT AND LIMITS FOR GLOVEBOX HC-21A}

CSER 94-007 (Altschuler, 1994a) for the furnace glovebox HC-21C set a 5 kilogram plutonium mass 7 imit (approximately 2 plutonium metal buttons) for slightly moderated $(\mathrm{H} / \mathrm{Pu}<20)$, a 2.0 Liter maximum limit on container size and a spacing limit of 10 inches between containers.

CSER 94-008 (Altschuler, 1994b) for the support glovebox HC-21A set a 5 kilogram plutonium mass 7 imit (approximately 2 plutonium metal buttons) for slightly moderated $(\mathrm{H} / \mathrm{Pu}<20)$ a 2.0 Liter maximum limit on container size and a spacing limit of 10 inches between containers.

Addendum 1 to CSER 94-007 and CSER 94-008 (Hess 1996a), allowed a container volume of 2.3 Liters, because the new Hastelloy- $X$ furnace boats had a volume greater than 2.0 liters. The previous furnace boats had a volume of only 1.5 Liters. The 5 kilogram plutonium mass limits and spacing limits remained for both $\mathrm{HC}-21 \mathrm{C}$ and $\mathrm{HC}-21 \mathrm{~A}$.

Addendum 2 to CSER 94-007 and CSER 94-008 (Chaio 1996), permits burning of whole plutonium metal buttons $(<2,500$ grams plutonium). The new description of the limit included: only one metal button is to be processed per furnace at a single time.

CSER 96-003 (Hess 1996b), for glovebox HC-21A did not change mass limits of 5 kilograms of plutonium, but did eliminate the 10 inch spacing requirements that were untenable for inserting cans back to back through the sphincter port or for pouring powders from one container to another. Additionally, the sieve shaker that was previously assumed to be the sieve catch pan and 3 (three) screen pans for a volume of:

$$
\pi / 4 *(8 \text { in. })^{2 *}(2 \text { in. }+3 * 2 \text { in. })=402 \text { in. }^{3} \Rightarrow 6.6 \text { Liters. }
$$

became limited to 2 (two) screen pans for a volume of:

$$
\pi / 4 *(8 \text { in. })^{2 *}(2 \text { in. }+2 * 2 \text { in. })=302 \text { in. }^{3} \Rightarrow 5.0 \text { Liters. }
$$

CSER 96-008 (Hess 1996C), for muffle furnace gloveboxes (HC-21C and HA-21I) set a mass 7 imit of 15 kilograms of plutonium compound (six furnace boats at no more than 2.5 kilograms of plutonium per furnace boat) OR when piutonium metal is present, the mass 1 imit becomes $7.5 \mathrm{kilograms}$ of plutonium. Additional limits are water content limited to $0.60 \mathrm{~g} \mathrm{H}_{2} \mathrm{O} / \mathrm{cm}^{3}$ and maximum density for plutonium compounds of $5 \mathrm{~g} \mathrm{Pu} / \mathrm{cm}^{3}$ before burning. The 10 inch spacing requirement was eliminated for the muffle furnace gloveboxes. 
WHC-SD-SQA-CSA-520 Rev. 0

This represented a change in philosophy from limitations on available plutonium and restriction on available container volumes to a scheme for maintaining a geometrically favorable (for precluding criticality) configuration for any fissile accumulation. The el imination of any lateral spacing requirement precluded the possibility of spacing infractions.

\subsection{INCENTIVES FOR REVISED LIMITS}

The present furnace glovebox limit of 2.5 kilograms plutonium per container is not acceptable when cans are to be loaded to approximately $5 \mathrm{~kg}$ $\mathrm{PuO}_{2}(4.41 \mathrm{~kg} \mathrm{Pu})$. This increased amount of plutonium per container is the incentive for revised glovebox limits. This criticality evaluation includes reconsideration of the previous limit of $5 \mathrm{~kg} \mathrm{Pu}$.

CSER 96-008 (Hess 1996c) had the following to say about the change from a spacing limit to a boat mass limit:

The $5 \mathrm{~kg}$ total Pu limit for the whole glovebox, although restrictive, has not been a particular impediment to the process throughput rate when most of the scraps and sludges to be stabilized were not of high Pu content.

A higher permitted Pu content for the whole glovebox is needed in order to expedite the throughput when firing more concentrated $\mathrm{Pu}$ bearing materials. In order to do this, the essence of criticality prevention has to be changed from rules for limiting total available Pu and for restricting the volume of Pu-bearing containers to a scheme for maintaining a geometrically favorable (for precluding criticality) configuration for any fissile accumulation. The adoption of the "cake pan" style boats of only 2.4 inches height will restrict the fissile material to a geometrically favorable slab configuration if boat stacking is prohibited and the Pu mass per boat is limited. The elimination of any lateral spacing requirement between six allowed boats then considerably eases the boat transfer operations and thus reduces the prospect for spacing infractions.

The operational mode, where there could be boats awaiting firing, being heated inside furnaces, or cooling on the stands outside of the furnace doors, determines a need for about two boats per furnace station to provide an optimized throughput for the processing. Thus, a limitation to six boats maximum for HA-21I is appropriate. Most containers in the PFP storage have a $2500 \mathrm{~g}$ upper 1imit on dry Pu bearing materials, and such a limit per furnace boat will not be inconvenient and can be readily supported as the basis for the slab geometry safety control, where boats can be arrayed side-by-side. These provisions will allow a total of $15 \mathrm{~kg} \mathrm{Pu}$, maximum, in HA-21I for stabilization of plutonium oxide compounds. If buttons are to be burned, the 7 imit is reduced to $7.5 \mathrm{~kg}$ of $\mathrm{Pu}$ in the metal form. 
HC-21C has only two muffle furnaces, but also houses a balance scale and room for one or two desiccators. Since the essential control is the prohibiting boat stacking. and the lateral distance of boats inside or outside of furnaces or desiccators is not restricted, the limit of six loaded boats in $\mathrm{HC}-21 \mathrm{C}$ with also no more than $15 \mathrm{~kg}$ total $\mathrm{Pu}$ as compound powders or $7.5 \mathrm{~kg}$ if large metal pieces is also satisfactory.

\subsection{NEW CRITICALITY LIMITS LOGIC, RATIONALE, AND JUSTIFICATION}

This section provides the logic, rationale and directions to the appropriate document location for the justification for design features and administratively controlled limits.

1. Plutonium metal glovebox 7imit. This is consistent with Hess (1996c) set glovebox limits for muffle furnace gloveboxes. HC-21C and HA-21I, but permits $\mathrm{Pu}$ in $\mathrm{PuO}_{2}$ as part of the 1 imit for Pu metal. This was also justified because of seismic concerns because $\mathrm{HC}-21 \mathrm{~A}$ is not a seismically qualified glovebox and a catastrophic rearrangement of the entire glovebox mass can be argued to remain subcritical.

2. Plutonium metal in furnace boat limit. This is consistent with Hess (1996c) set glovebox limits for muffle furnace gloveboxes, HC-21C and HA-21I .

3. Plutonium oxide glovebox 1imit. This is consistent with Hess (1996c) set glovebox limits for muffle furnace gloveboxes, HC-21C and HA-21I. This was also justified because of seismic concerns because HC-21A is not a seismically qualified glovebox and a catastrophic rearrangement of the entire glovebox mass can be argued to remain subcritical.

4. Mass and volume limits for separate operations. These are derived from the basic critical parameters for Pu form and content section, mostly these limits are consistent with the Table 6.1. Criticality Parameters for Spherical Configurations, ${ }^{239} \mathrm{PuO}_{2}$-water Mixes, values. The 10 inch separation assures that these individual limits are applied to the operations separately.

5. PuO mass in a sieve shaker pan. This 1 imit is from the MONK6B results tabulated in Table 9.1, HC-21A Normal and Off-Normal MONK6B Results and the requirements of the double contingency criterion. In this case, the single contingency of adding another furnace boat of $2.5 \mathrm{~kg} \mathrm{Pu}$ into the sieve shaker pan and raising the mass from $6.0 \mathrm{~kg}$ Pu to $8.5 \mathrm{~kg}$ Pu sti11 calculates a $k_{\text {eff }}$ below 0.935 .

6. $\mathrm{PuO}_{2}$ mass in a $4.4 \mathrm{~kg}$ Pu can. This is needed because of assumptions made in other CSER's such as Erickson (1996) for other facilities.

7. Maximum number of filled $4.4 \mathrm{~kg}$ Pu cans in a glovebox. This 7 imit is from the MONK6B results tabulated in Tab7e 9.1. HC-21A Norma 1 and offNorma1 MONK6B Results and the requirements of the double contingency criterion. In this case. a cluster of one more than the maximum number of allowed filled $4.4 \mathrm{~kg}$ Pu cans should have a $k_{\text {eff }}$ below 0.935 . 
8. Maximum container volume. These criticality limits are as small as possible given the containers required to perform the operation. The maximum container volume is specified to preclude the volume necessary for criticality if water were to be mixed with exposed $\mathrm{PuO}_{2}$.

9. Maximum number of sieve screens used in the sieve screen system. This is from MONK6B results tabulated in Table 9.1, HC-21A Normal and 0ffNorma 7 MONK6B Results, and the requirements of the double contingency criterion. This limit prevents a single volume of more than 3.3 Liters and a combined container volume of 6.0 Liters so a usable limit of $6.0 \mathrm{~kg}$ and $7.5 \mathrm{~kg}$ on plutonium mass, respectively, is allowable. This limit by itself is not sufficient to assure $k_{\text {eff }}$ below 0.935 and there needs to be a container mass limit that will assure $k_{\text {eff }}$ below 0.935 in conformance with the double contingency criterion.

10. Stacking of plutonium bearing containers. Stacking could make a group of containers more like a sphere which is more reactive. This criticality limit is consistent with criticality limits for the muffle furnace gloveboxes (Hess 1996c). MONK6B calculations, shown in Table 9.1, HC-21A Normal and Off-Norma1 MONK6B Results, were performed with stacked boats containing plutonium metal, the most reactive configuration, and shown to have $k_{\text {eff }}$ below 0.935 in conformance with the double contingency criterion.

11. Pot sump sealing. Areas where volumes of plutonium bearing compounds may accumulate are to be minimized, reduced or eliminated as part of criticality control.

12. Maximum glovebox floor accumulation. This is routine, and is confirmed by MONK6B calculations tabulated in Table 9.1, HC-21A Normal and OffNormal MONK6B Results, and the requirements of the double contingency criterion. In this case, the maximum glovebox accumulation is included in limiting single contingency cases and it is required that $k_{\text {eff }}$ remain below 0.935 .

13. DRY glovebox. The confirmation of this designation requires criticality evaluation of the possibility of water introduction. Criticality evaluations consider container volume and contained plutonium mass and take into account flooding without plutonium position changes, which corresponds to fire fighting category $C$.

\subsection{BASIC CRITICAL PARAMETERS FOR PU FORM AND CONTENT}

\subsection{SPHERICAL GEOMETRY CORRELATIONS}

Table 6.1 presents critical parameter correlations, derived from standard handbook data for spherical geometry, expressed in a manner to illustrate the likelihood of such conditions existing within the muffle furnace and muffle furnace support ( $\mathrm{HC}-2 \mathrm{IA}$ ) gloveboxes. The footnotes to the table explain the typing formats used to indicate various normal and offnormal conditions. 


\section{WHC-SD-SQA-CSA-520 Rev. 0}

\subsubsection{Dry Plutonium Oxide}

The upper section of the table concerns only absolutely dry material boat charges, as would be the case for material after firing in the furnaces. Data 1 ine one shows a $12 \mathrm{~kg}$ minimum critical mass for ${ }^{239} \mathrm{Pu}$ as plutonium oxide, based on experiments with $9.96 \mathrm{~g} \mathrm{Pu} / \mathrm{cm}^{3}$ material (Paxton and Provost 1986). The next 1 ine, at $10.1 \mathrm{~g} \mathrm{Pu} / \mathrm{cm}^{3}$ (close to the theoretical highest density point of $11.46 \mathrm{~g} \mathrm{PuO} / \mathrm{cm}^{3} \times 239.0522 /(239.0522+2 \times 15.9994)=$ $10.107 \mathrm{~g} \mathrm{Pu} / \mathrm{cm}^{3}$ ) is from the ARH-600 (Carter et.al. 1968) chart of calculated values for $\mathrm{PuO}_{2}$, which indicates a slightly lower critical mass $(10.8 \mathrm{~kg}$ with full reflection), indicating that the chart-derived data is likely to be somewhat conservative. Also conservative is the assumption of $100 \%{ }^{230} \mathrm{Pu}$.

This second line also shows that with nominal reflection, the $15 \mathrm{~kg}$ of $\mathrm{Pu}$ al lowed as a glovebox 1 imit could nearly be made critical; but having $\mathrm{PuO}_{2}$ at theoretical density is not credible, nor is a factor of 6 overbatch in one boat volume. With full water reflection (deemed implausible because HC-21A is open on the north end to the conveyor glovebox, $\mathrm{HC}-2), 15 \mathrm{~kg}$ of dry $\mathrm{Pu}$ as $\mathrm{PuO}_{2}$ could become critical at a lower density, $8.0 \mathrm{~g} \mathrm{Pu}^{\mathrm{cm}^{3}}$. above the anticipated density for $\mathrm{PuO}_{2}$, and is not a credible concentration for material in this stabilization process or from past PFP/PRF operations.

The furnace firing usually condenses the charged material, but it is not likely for the Pu to be concentrated to more than $6 \mathrm{~g} \mathrm{Pu} / \mathrm{cm}^{3}$. At $6 \mathrm{~g} \mathrm{Pu} / \mathrm{cm}^{3}$ of Pu as dry oxide, criticality requires at least $24 \mathrm{~kg}$ Pu crammed into a 4 liter accumulation (about two boats) with full reflection. This means multiple violations of the $15 \mathrm{~kg}$ total glovebox Pu limit and also a flooded scenario (for full reflection). At lower Pu densities, a dry criticality needs even higher masses and volumes. For a more probable upper Pu density at $4.7 \mathrm{~g} \mathrm{Pu} / \mathrm{cm}^{3}$, at least $33 \mathrm{~kg}$ of $\mathrm{Pu}$ is needed with full reflection, and over 60 $\mathrm{kg}$ with nominal reflection. Thus, without even considering the geometry restriction imposed by the plutonium container spacing limits, criticality for dry material with any plausible Pu concentration would be impossible unless all the plutonium containers were nearly triple-batched (or nearly double batched if flooding were possible). This argument also applies to plutonium oxide in the other containers in glovebox $\mathrm{HC}-21 \mathrm{~A}$.

\subsubsection{Wet Plutonium 0xide}

The lower section of Table 6.1 contains parameters for plutonium oxide at various densities fully soaked with water (i.e., with water filling the available void space between $\mathrm{PuO}_{2}$ granules). It is assumed that each 1 $\mathrm{g} \mathrm{Pu} / \mathrm{cm}^{3}$ as oxide occupies 10 vofume percent (v/o). This assumption is consistent with previously stated PuO densities of $9.96 \mathrm{~g} \mathrm{Pu} / \mathrm{cm}^{3}$ and $10.1 \mathrm{~g} \mathrm{Pu} / \mathrm{cm}^{3}$. Scrap or sludge materials, as initial charges to the boats. are more likely to contain water, but water contents exceeding $60 \mathrm{v} / 0$ are highly unlikely. Pu densities over $5 \mathrm{~g} \mathrm{Pu} / \mathrm{cm}^{3}$ are not plausible for pre-fired materials except for plutonium metal buttons, and for much lower densities there is likely to be significant volume fractions of lighter element oxides and other materials. 


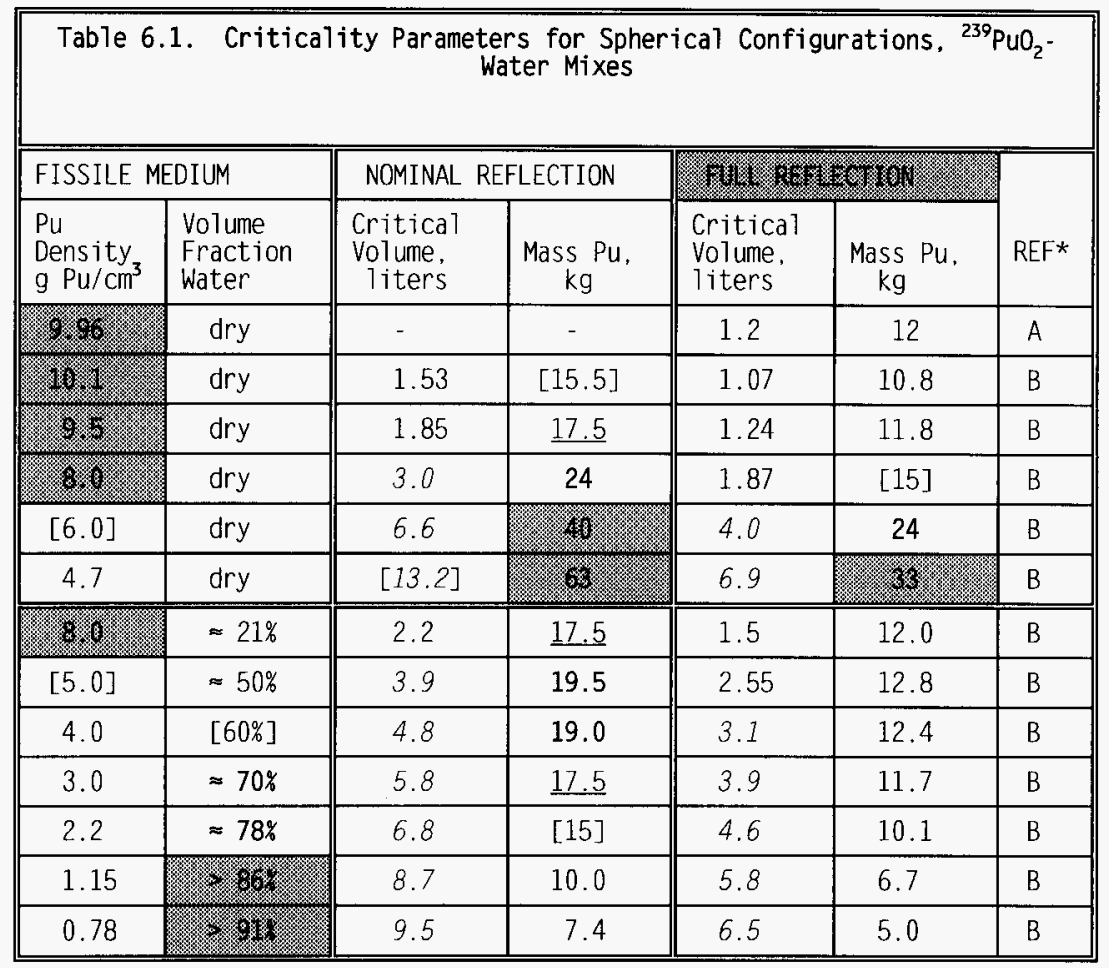

NOTE: As pertains to operations under glovebox CPS Limits allowing six. 2.2 Liter boats maximum with not more than $2.5 \mathrm{~kg}$ Pu per boat, stacking prohibited, but no lateral spacing rules:

[Bracketed] items are glovebox mass or volume limit, or maximum likely density Underlined mass value is 1 -boat $(2.5 \mathrm{~kg})$ overload of glovebox total Pu 7 imit. Italicized volumes imply stacking or dumping to get spherical approximation Bold items are unlikely material conditions or multiple mass overloading 3.6.6\%: items are implausible conditions.

* Data Sources:

A) LA-10860-MS, pg 70, Tab7e 16, from experiments _ [Paxton and Provost 1986]

B) ARH-600 Chart III.A.9(100)-5 
The correlations for nominally-reflected, wet material in Table 6.1 give two critical points for $17.5 \mathrm{~kg}$ Pu, which would be the allowed contents of 7 boats, as an infraction of the limit on number of loaded boats, fully loaded. But the material would have to be either in one boat volume at an impossible density of $8 \mathrm{~g} \mathrm{Pu} / \mathrm{cm}^{3}$, or at $3 \mathrm{~g} \mathrm{Pu} / \mathrm{cm}^{3}$ soaked to an improbable water content of $70 \mathrm{v} / 0$ in almost three boats. Since other volumes in glovebox $\mathrm{HC}-21 \mathrm{~A}$ are less than that of a boat, except for the sieve pan with one screen, and mass limits are less than $1 / 2$ the $17.5 \mathrm{~kg}$ for containers, this argument again applies to glovebox HC-21A. The sieve pan and screen with a volume of 3.3 Liters is still less than that needed for criticality except for the improbable density of $8 \mathrm{~g} \mathrm{Pu} / \mathrm{cm}^{3}$.

With all of the $15 \mathrm{~kg}$ Pu allowed in the glovebox clustered into one contiguous volume, the nominally-reflected critical density is $2.2 \mathrm{~g} \mathrm{Pu} / \mathrm{cm}^{3}$. which is more typical of materials encountered at PFP; however, soaking to $78 \%$ by volume water would be needed as well as double batching of 3 boats, plus stacking. Similar multiple infractions of limits are needed in $\mathrm{HC}-21 \mathrm{~A}$ to assemble $15 \mathrm{~kg}$ of plutonium and 7 Liters of containers.

With full reflection and plausible maximum water contents (no more than $60 \mathrm{v} / 0$ in the assumed pure oxide/water mixture) criticality would require at least $12 \mathrm{~kg} \mathrm{Pu}$. This mass is under the glovebox limit, but it would need to occupy less than two boats of volume so the scenario would violate the mass limit per boat or other container. For improbable water fractions of between 60 and 78\%, again with full reflection, there would still have to be $10 \mathrm{~kg} \mathrm{Pu}$ or more as esssentially two double-batched boat loads. $10 \mathrm{~kg} \mathrm{Pu}$ at $1.15 \mathrm{~g} \mathrm{Pu} / \mathrm{cm}^{3}$ as four allowed boat loads could be made critical, but such would mean two stacking errors plus an implausible $86 \mathrm{v} / 0$ water content. For $\mathrm{HC}-21 \mathrm{~A}$, the spacing requirements would have to be violated for reasonable $\mathrm{PuO}_{2}$ densities less than $6 \mathrm{~g} \mathrm{PuO}_{2} / \mathrm{cm}^{3}$.

The last line in Table 6.1 indicates that $5 \mathrm{~kg} \mathrm{Pu}$ (or twice that allowed per boat) configured as a sphere could only be made critical as essentially a solution or thin slurry. Besides this violation of the allowed material consistency, to get the accumulation configured anywhere approaching a spherical shape would entail multiple spacing errors or use of a single container of twice the volume allowed for containers. Although $5 \mathrm{~kg} \mathrm{PuO}$ is allowed in a convenience can, the 1.24 Liter volume or inner can 1.42 Liter volume is insufficient for criticality. The other containers in $\mathrm{HC}-21 \mathrm{~A}$ are limited to about half the volume necessary for criticality.

The Table 6.1 correlations thus show that under the proposed limits on container groupings, their loading and spacing requirements, criticality would require multiple error conditions, so that the double contingency criteria for assured subcriticality is satisfied. Further, because the glovebox has an open end, water could not accumulate to give significant water reflection. Since the plutonium is either metal or oxide, it is not soluble, so it would have to be agitated to a homogeneous $\mathrm{PuO}_{2} / \mathrm{H}_{2} \mathrm{O}$ mixture of at least the spherical volume needed for a potential criticality. There is no postulated mechanism for suspension of $\mathrm{PuO}_{2}$ in $\mathrm{H}_{2} \mathrm{O}$ in the container. Criticality in the amounts available and the containers is considered incredible 


\section{WHC-SD-SQA-CSA-520 Rev. 0}

\subsection{SLAB GEOMETRY CORRELATIONS}

There is a concern about the plutonium in boats and a sieve stack if in error they were put side by side or a spill put $\mathrm{Pu}$ next to the sieves or the boats. A clustering of two boats and sieve pan begins to approximate a slab configuration. Table 6.2 lists data from Criticality Handbooks (Paxton and Provost 1986. Carter et.al. 1968) pertaining to infinite-slab criticality parameters for pure Pu-water mixes (a11 $\mathrm{Pu}$ is ${ }^{239} \mathrm{Pu}$ ), at ful1 soaking without void spaces or other constituents. Except for last line, the first four data columns relate to Pu-water mixes, but the water content listed in the 5 th column is for plutonium-oxide plus water: this listing is conservative. because the oxide mixes gives lower $\mathrm{H} / \mathrm{Pu}$ ratios than the critical ratios inherent to the Pu/water parameters, and with less than $95 \mathrm{v} / 0$ water the fissile medium is undermoderated.

The defining data for the Table 6.2 listing of parameters is the critical areal Pu density. which is derived as the boat loading divided by the outside footprint $381 \mathrm{~cm}_{2}\left(0.410 \mathrm{ft}^{2}\right)$ per boat. Then, the critical depth (slab thickness) is read off the cited ARH-600 chart for the given areal density. Finally, a volumetric density $\left(\mathrm{g} \mathrm{Pu} / \mathrm{cm}^{3}\right)$ is established by dividing the Pu mass per boat by the loading volume, which is determined as the depth times the boat inside footprint $355 \mathrm{~cm}^{2}\left(0.382 \mathrm{ft}^{2}\right)$. A slab thickness of more than $6.20 \mathrm{~cm}(2.44 \mathrm{in}$.) represents overfilling of boats. For the water content in the last column, it is assumed the $\mathrm{Pu}$ is $\mathrm{PuO}_{2}$ so that each $1 \mathrm{~g}$ $\mathrm{Pu} / \mathrm{cm}^{3}$ represents $\approx 10 \mathrm{v} / 0 \mathrm{PuO}_{2}$.

This data for boats with normal charges and multiple overcharges is applicable for a $0.3175 \mathrm{~cm}(0.125 \mathrm{in}$.) thick layer in the bottom of the glovebox, the boats, and for the sieve pan, which is $5.08 \mathrm{~cm}$ (2 in.) tall. The sieve pan, with one screen is addressed in Section 6.1. The sieve pan has a footprint of only:

$$
\pi / 4 *(8 \text { in. } / 12 \text { in. } / \mathrm{ft})^{2}=0.349 \mathrm{ft}^{2}=324.3 \mathrm{~cm}^{2} \text {, }
$$

which is less than a boat, and gives the next higher areal density. Since the pan is only $5.08 \mathrm{~cm}$ (2 in.) high, the results are still conservative. Also, the round pan with rectangular boats leaves a lot of open space. A square of the pan diameter has a bigger footprint than a boat.

\subsubsection{Nominally Reflected Slab}

With only nominal reflection above and below the slab (a 1-tier array of boats), the first section of Table 6.2 shows that criticality is not possible without at least two abnormal/implausible conditions. With no more than the allowed boat $\mathrm{Pu}$ loadings $(2.5 \mathrm{~kg}$ each), criticality would require over $90 \mathrm{v} / 0$ water overfilling the boats, for which consistency the material would flow.

A criticality for just brim-high filling of the boats (depth $=6.20 \mathrm{~cm}=$ 2.44 in.), would require a fully soaked $4.0 \mathrm{~g} \mathrm{Pu} / \mathrm{cm}^{3}$ material, which is just at the $60 \mathrm{v} / 0$ water limit. However, now there would be $8.8 \mathrm{~kg}$ of Pu in every boat, greater than triple batching for all boats. This is a not believable error situation (also see section 9.2.11 on water ingress due to fire). 
WHC-SD-SQA-CSA-520 Rev. 0

\begin{tabular}{|c|c|c|c|c|c|c|}
\hline \multicolumn{7}{|c|}{$\begin{array}{c}\text { Table 6.2. Criticality Parameters for Slab Geometry Configurations of }{ }^{239} \mathrm{Pu} \text { - } \\
\text { Water Mixes }\end{array}$} \\
\hline $\begin{array}{l}\text { REFLECTION } \\
\text { CONDITIONS }\end{array}$ & $\begin{array}{l}\text { KG PU } \\
\text { IN EVERY } \\
\text { BOAT }\end{array}$ & $\begin{array}{l}\text { AREAL PU } \\
\text { DENSITY } \\
\mathrm{kg} / \mathrm{ft}^{2} \\
\end{array}$ & $\begin{array}{l}\text { CRITICAL } \\
\text { DEPTH, } \\
\text { inches } \\
\end{array}$ & $\begin{array}{l}\text { CHARGE } \\
\text { DENSITY } \\
\text { g Pu/ } / \mathrm{cm}^{3}\end{array}$ & $\begin{array}{l}\text { VOLUME } \\
\text { FRACTION } \\
\text { WATER }^{\star}\end{array}$ & $\begin{array}{l}\text { DATA } \\
\text { SOURCE } \\
\star \star\end{array}$ \\
\hline \multirow{6}{*}{$\begin{array}{l}\text { NOMINAL } \\
\text { Represented } \\
\text { by 1" water } \\
\text { above and } \\
\text { below } \\
\text { boat array }\end{array}$} & {$[2.5]$} & 6.1 & 3.6 & 0.77 & $.92 \%$ & $A$ \\
\hline & 3.0 & 7.3 & 3.5 & 0.95 & $=90 \%$ & $A$ \\
\hline & 5.0 & 12.2 & 3.15 & 1.76 & $\approx 82 \%$ & $A$ \\
\hline & 6.0 & 14.6 & 2.97 & 2.24 & $\approx 78 \%$ & A \\
\hline & 8.8 & 21.5 & {$[2.44]$} & 4.0 & {$[\approx 60 \%]$} & $A$ \\
\hline & 10 & 24.5 & 2.22 & {$[5.0]$} & $\approx 50 \%$ & $A$ \\
\hline 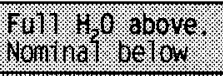 & {$[2.50]$} & 6.1 & 2.78 & 1.0 & $.90 \%$ & B \\
\hline 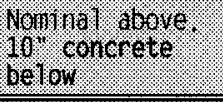 & 2.14 & 5.2 & 2.39 & 1.0 & $=90 \%$ & B \\
\hline \multirow{8}{*}{ 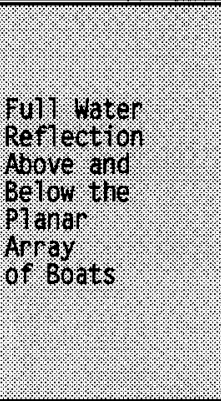 } & 0.35 & 0.86 & {$[2.44]$} & 4.16 & (. $99 \%$ & A \\
\hline & 1.77 & 4.32 & 1.95 & 1.01 & $\approx 90 \%$ & $A$ \\
\hline & {$[2.5]$} & 6.1 & 1.80 & 1.54 & $\approx 85 \%$ & A \\
\hline & 4.65 & 11.7 & 1.30 & 4.00 & {$[\approx 60 \%]$} & A \\
\hline & $\underline{5.00}$ & 12.2 & 1.20 & 4.62 & $\approx 54 \%$ & A \\
\hline & $\underline{5.17}$ & 12.6 & 1.14 & {$[5.0]$} & $\approx 50$ & A \\
\hline & 6.0 & 14.6 & 0.91 & 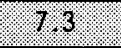 & $<27 \%$ & A \\
\hline & 6.1 & 14.8 & 0.68 & 9.96 . & $\begin{array}{l}\mathrm{DRY} \\
\mathrm{PUO}_{2}\end{array}$ & $\mathrm{C}$ \\
\hline
\end{tabular}

* Assumes $\mathrm{PuO}_{2}$-water mix, although critical parameters are for Pu-water.

NOTE: AS pertains to CPS 7imit of $2.5 \mathrm{~kg}$ per boat, with stacking prohibited;

[bracketed] items are at-limit mass or density values, or boat brim height

Bold slab depths exceed boat height, which is implausible for finite 1 tier of boats when mix is fluid (greater than $70 \mathrm{v} / 0$ water)

Underlined masses are near double batches (in all boats of infinite array)

Bold mass, Pu density or water contents are highly unlikely conditions

Sroodor. items are implausible conditions.

** Data Sources:

A) ARH-600 Chart III.A.8(100)-3

B) ARH- 600 Chart III.A.5(100)-5

C) LA-10860-MS, page 70, Table 16
[Carter et.a1. 1968]

[Carter et.a1. 1968]

[Paxton and Provost 1986] 


\subsubsection{Slab with Full Reflection Above or Below}

In the second set of data in Table 6.2, it is assumed that there is nominal reflection on one face of the slab, but full reflection on the other. If flooding of the glovebox were possible, an infinite array of boats on the elevated glovebox floor loaded to the allowed $2.5 \mathrm{~kg}$ per boat could be criti cal if the $\mathrm{PuO}_{2}$-water mixture was $7.06 \mathrm{~cm}$ (2.78 in.) deep and the Pu was diluted to $1 \mathrm{~g}^{2} \mathrm{Pu} / \mathrm{cm}^{3}$. Thus, even if a $25 \mathrm{~cm}$ (10 in.) deep flooding event was plausible, some action would be needed to bring the full boat charges up to $0.86 \mathrm{~cm}(0.3 \mathrm{in.})$ above the brim, and since a real array would not cover the whole floor the excess height of this dilute mix would drain off.

The second line of the second data set represents the boat array sitting of a concrete floor, somehow being soaked to a highly liquid $90 \% \mathrm{H}_{2} \mathrm{O}$ content. This scenario is completely out of scope as it would involve severe misconduct of operations. The data points in this second set are at the upper end of $\mathrm{Pu}$ concentration on the graph curves of reference $B$ shown in Table 6.2. Critical $\mathrm{Pu}$ concentrations less than $1 \mathrm{~g} \mathrm{Pu} / \mathrm{cm}^{3}$ would require even higher slab depths.

\subsubsection{Fully Reflected S1ab}

In the bottom portion of Table 6.2, full water reflection is assumed both above and below the slab array of boats. This configuration not plausible unless a.) considerable amount of reflective materials are stored just beneath the glovebox, and b.) a lot of water is introduced inside. Given these two extreme contingencies, criticality would be possible with allowed boat loadings if the flooding could also agitate all boat charges with water and mix such to a dilute slurry, with over $85 \mathrm{v} / 0$ water and the Pu at $1.5 \mathrm{~g} \mathrm{Pu} / \mathrm{cm}^{3}$ or less density. The first three lines of the last data set represent such an unlikely scenario. A third contingency, under which criticality would be possible even with more realistic $\mathrm{PuO}_{2} /$ water mixture densities, is if all the boats were overloaded.

The last line of Table 6.2 data is based on an experimental determination of the critical thickness for an infinite slab of solid $\mathrm{PuO}_{2}$ fully reflected on both sides. Reference $C$ of Table 6.2 cites a thickness of $1.6 \mathrm{~cm}\left(0.63\right.$ inches) with the $\mathrm{Pu}$ at $9.96 \mathrm{~g} / \mathrm{cm}^{3}$. This combination equates to a critical areal density of $15.9 \mathrm{~g} \mathrm{Pu} / \mathrm{cm}^{2}$ (14.8 $\mathrm{kg} \mathrm{Pu} / \mathrm{ft}^{2}$ ). To achieve the same average areal density for an array of boats loaded with this dry material, the $\mathrm{PuO}_{2}$ in the boats would have to be $1.7 \mathrm{~cm}(0.68 \mathrm{in}$.) deep $(0.63 \times$ ratio of outside/inside footprints). The critical boat loadings would be $15.9 \mathrm{~g} \mathrm{Pu} / \mathrm{cm}^{2}$ $\star 381 \mathrm{~cm}^{2}=\left(14.8 \mathrm{~kg} / \mathrm{ft}^{2} \times 0.41 \mathrm{ft}^{2}\right)=6.1 \mathrm{~kg} \mathrm{Pu}$ each. Although it was measured for near full density oxide (at $\approx 10 \mathrm{gPu} / \mathrm{cm}^{3}$ ), the $15.9 \mathrm{gPu} / \mathrm{cm}^{2}$ (14.8 kg Pu/ $\mathrm{ft}^{2}$ ) critical point would logically apply for any density of dry plutonium oxide as an infinite, full-water-reflected slab. This condition requires multiple errors of total $\mathrm{PuO}_{2}$, spacing, spil1 depth, and boat or sieve overloading.

Thus, for the stated fissile medium (pure ${ }^{239} \mathrm{Pu}$ as oxide fully soaked with water), criticality is not plausible for an infinite 1-tier boat array, $0.3175 \mathrm{~cm}(0.125 \mathrm{in.})$ thick floor layer of $\mathrm{PuO}_{2}$, or sieve pan for even one contingency beyond the conditions allowed in $\mathrm{HC}-21 \mathrm{~A}$. The open ended glovebox and lack of agitation to suspend the $\mathrm{PuO}_{2}$ makes a critical slab incredible. 
WHC-SD-SQA-CSA-520 Rev. 0

\subsection{MONK6B MONTE-CARLO GLOVEBOX MODELING}

\subsection{METHODS VALIDATION}

Appendix $B$ provides a standardized summary for the documentation of the validation (Macklin and Miller 1992. Mi 1ler 1994) carried out for the MONK6B Monte-Carlo code, and its predecessor versions, as applicable to plutonium materials encountered at PFP. With the cross-section library supplied, the MONK6A/6B validation calculations indicate an allowed maximum $k_{\text {eff }}$ value of 0.935 for new system calculations to assure subcriticality with an acceptable margin, including the uncertainties in the analytical methods and benchmark experimental data.

The MONK6B code was used for this analysis. This code is commercially licensed from the British ANSWERS organization. The MONK6B code uses cross sections from a point energy library based on the UKNDL and JEF evaluations. It is currently verified and validated on two Sun workstations in the SECC.

\subsection{MODELING ASSUMPTIONS WITH PLUTONIUM METAL BUTTONS}

For this analysis the plutonium metal buttons were modeled with dimensions of $7.1 \mathrm{~cm}(2.8 \mathrm{in}$.) 0.0 and $3.244 \mathrm{~cm}(1.277 \mathrm{in}$.) height. The plutonium was modeled as $100 \mathrm{wt} \%{ }^{239} \mathrm{Pu}$ with a number density of 0.049034 . The metal density calculates to:

$$
0.049034 * 10^{24} * 239.0522 / 6.022045 \mathrm{E} 23=19.464 \mathrm{~g} \mathrm{Pu} / \mathrm{cm}^{3} \text {. }
$$

This density calculates the mass for a single plutonium metal button to:

$$
19.464 \mathrm{~g} \mathrm{Pu} / \mathrm{cm}^{3} * \pi *(3.55 \mathrm{~cm})^{2} * 3.244 \mathrm{~cm}=2,500.0 \mathrm{~g} \mathrm{Pu} \text {. }
$$

This plutonium enrichment is limiting and conservative and the plutonium mass per plutonium metal button is also limiting and conservative.

\subsubsection{Plutonium Metal in HC-21A Normal and Off-Normal Conditions}

The plutonium metal buttons are modeled inside furnace boats, usually centered, because this is their typical HC-21A location. The furnace boats may be adjacent in a side by side geometry. The glovebox is modeled with interior dimensions of $266.7 \mathrm{~cm}$ (105 in.) long, $106.68 \mathrm{~cm}$ (42 in.) deep, and $91.44 \mathrm{~cm}$ (36 in.) high. There is $2.54 \mathrm{~cm}$ ( 1 inch) water reflection on all sides, radial and top of the plutonium metal buttons, and outside all containers. The glovebox sides, top, and bottom are $0.635 \mathrm{~cm}(0.25$ inch) thick stainless steel plate that is $137.16 \mathrm{~cm}$ ( 54 in.) above a concrete floor. There is a full $30 \mathrm{~cm}$ of water reflection outside the glovebox on al1 sides. This model is used for the normal and off-normal calculations in Table 9.1 HC-21A Normal and Off-Norma1 MONK6B Results. 


\subsubsection{Plutonium Metal in Parametric Study Calculations}

The plutonium metal buttons along with the dry plutonium compounds are modeled together in a very conservative geometry. The conservative geometry is that the plutonium metal buttons are stacked, which is a violation of criticality limits, and the $\mathrm{PuO}_{2}$ surrounds the buttons in a cylinder, which is another violation of criticality limits. The cylinder was calculated with the diameter equal to height $(H / D=1)$ to give a maximum in reactivity. There is $5.08 \mathrm{~cm}$ ( $2 \mathrm{in}$.) water reflection on al1 sides, radial and top. The assembly bottom is on a $0.635 \mathrm{~cm}(0.25$ inch $)$ thick stainless steel plate that is $121.92 \mathrm{~cm}$ (4 feet) above a concrete floor. The glovebox is conservatively modeled as a $91.44 \mathrm{~cm}$ ( 36 inch) diameter cylinder. There is a fuil $30 \mathrm{~cm}$ of water reflection outside the glovebox on the sides. This model is used for the parametric study calculations in Table 9.2. Plutonium Metal and Plutonium oxide MONK6B Results.

\subsection{MODELING ASSUMPTIONS WITH 4.4 KILOGRAM PLUTONIUM CANS}

For the purposes of this analysis, only the innermost can was modeled. The can is filled with $5.0 \mathrm{~kg}$ of plutonium in $\mathrm{PuO}_{2}$ with $\mathrm{H}_{2} \mathrm{O}$ added for an $\mathrm{H} / \mathrm{Pu}=2$. The maximum assumed Pu density is $5.5 \mathrm{~g} \mathrm{Pu} / \mathrm{cm}^{32}$. The plutonium is assumed to be 100 wt\% ${ }^{239} \mathrm{Pu}$. This plutonium enrichment is limiting and is conservative.

The dry $\mathrm{PuO}_{2}$ returned from the muffle furnaces is modeled in the convenience cans clustered together. The plutonium is assumed to be $100 \mathrm{wt} \%$ ${ }^{239} \mathrm{Pu}$. This plutonium enrichment is limiting and is conservative.

The density considered in these calculations is $5.5 \mathrm{~g} \mathrm{Pu} / \mathrm{cm}^{3}$ in the $\mathrm{PuO}_{2}$. This means that the $\mathrm{PuO}_{2}$ density considered is:

$$
5.5 \mathrm{~g} \mathrm{Pu} / \mathrm{cm}^{3} *((239.0522+2 * 15.9994) / 239.0522)=6.236 \mathrm{~g} \mathrm{PuO} / \mathrm{cm}^{3} \text {. }
$$

The density of single crystals of $\mathrm{PuO}_{2}$ is 11.46 . To achieve a practical density of $6.236 \mathrm{~g} \mathrm{PuO} / \mathrm{cm}^{3}$ from a collection of single grains, the porosity (interstitial void spaces) would have to be:

$$
100 \% *(1 .-(6.236 / 11.46))=45.585 \% \text { or less. }
$$

Weakly cemented rocks that are formed of grains dropped as sediment from a suspension, such as sand, sandstone and some limestones, have a porosity range of $25 \%$ to $45 \%$. For a tapped collection of $\mathrm{PuO}_{2}$ grains without application of pressure, this $45 \%$ porosity is not considered to be practical to achieve.

The highest tap density for $\mathrm{PuO}_{2}$ reported (ARH-600 Table II.C.2-2) was only $5.8 \mathrm{~g} \mathrm{PuO} / \mathrm{cm}^{3}$, inferring a porosity of:

$$
100 \% *(1 .-(5.8 / 11.46))=49.4 \% \text { minimum. }
$$

Because the calculated $\mathrm{PuO}_{2}$ density is much greater that historical experience of $\mathrm{PuO}_{2}$ density, the calculations performed at this density are considered to be conservative. 
WHC-SD-SQA-CSA-520 Rev. 0

\subsection{DISCUSSION OF CONTINGENCIES}

Contingencies were considered as Nuclear Criticality Safety Parameters. The following parameters were addressed: 1. Mass, 2. Enrichment, 3. Volume, 4. Geometry, 5. Concentration/Density, 6. Moderation, 7. Interaction, 8. Reflection, 9. Neutron Absorption, and 10. Other.

(1) Mass: There is a glovebox mass 7 imit, so one contingency is: glovebox mass limit exceeded. There is a container mass 1 imit of $2.5 \mathrm{~kg} \mathrm{Pu}$ metal for any container, so a second contingency is: $2.5 \mathrm{~kg}$ plutonium metal mass container limit exceeded. Another limit on mass is of $6.0 \mathrm{~kg}$ plutonium in a plutonium compound for any container, so a third contingency is $6.0 \mathrm{~kg} \mathrm{Pu}$ in $\mathrm{PuO}_{2}$ mass container limit exceeded. Another limit on mass is on the number of filled $4.4 \mathrm{~kg}$ cans, so a fourth contingency is filled $4.4 \mathrm{~kg}$ Pu can number limit exceeded.

(2) Enrichment: There is no enrichment 1 imit and all cases were calculated at, conservatively, $100 \mathrm{wt} \%{ }^{239} \mathrm{Pu}$, so there is no enrichment based contingency.

(3) Volume: There are volume limits on containers, so a fifth contingency is container volume limit exceeded.

(4) Geometry: Geometry is limited by not stacking containers with plutonium, so a sixth contingency is stacking of plutonium bearing containers. Geometry is also limited by not moving a plutonium bearing materials such as a transport wagon underneath the $\mathrm{HC}-21 \mathrm{~A}$ glovebox, so a seventh contingency is transport wagon underneath glovebox.

(5) Concentration/Density: The density for plutonium oxide used in this CSER is a conservative density of $5.5 \mathrm{~g} \mathrm{Pu} / \mathrm{cm}^{3}$ based on the most dense limit allowed, the vertical calciner product (Geiger 1995). This $\mathrm{PuO}_{2}$ density is higher than a11 criticality handbook (Carter et. al. 1968) entries for $\mathrm{PuO}_{2}$ densities. A reasonable, $19.464 \mathrm{~g} \mathrm{Pu} / \mathrm{cm}^{3}$. density was used for plutonium metal density.

MONK6B calculations were performed at these densities. Reactivity goes up as the $\mathrm{PuO}_{2}$ density goes up. so the assumptions used in the computer calculations need to be conservative. This $5.5 \mathrm{q} \mathrm{Pu} / \mathrm{cm}^{3}$ density is very conservative. $5.5 \mathrm{~g} \mathrm{Pu} / \mathrm{cm}^{3}$ equals $6.23 \mathrm{~g} \mathrm{PuO} / \mathrm{cm}^{3}$.

There is no density based contingency because the values used in these calculations are considered sufficiently conservative.

(6) Moderation: Moderation is controlled because plutonium compounds are 7 imited to $\mathrm{H} / \mathrm{Pu} \leq 2$, so an eighth contingency is: $\mathrm{H} / \mathrm{Pu}>2$ material inside glovebox.

(7) Interaction: Interaction is explicitly limited by horizontal spacing requirements and by container stacking limits (covered as a geometry contingency), the container cluster interaction contingency is covered as a ninth contingency. 
(8) Reflection: Reflection is controlled because HC-21A is classified as a DRY glovebox without flowing liquids and only limited size containers of moisture bearing materials, so a tenth contingency is introduction of water into glovebox.

(9) Neutron Absorption: Neutron absorbing materials are not specified as part of any safety system. so there is no contingency associated with neutron poisons.

(10) Other: Other, at Hanford, has come to mean fire and seismic concerns, so an eleventh contingency is water ingress due to fire, and an twelfth contingency is seismic concerns.

The contingencies to be considered by MONK6B calculations are:

1) Glovebox Mass Limit Exceeded.

2) $2.5 \mathrm{~kg}$ Plutonium Metal Mass Container Limit Exceeded,

3) $6.0 \mathrm{~kg} \mathrm{Pu}$ in $\mathrm{PuO}_{2}$ Mass Container Limit Exceeded,

4) Filled $4.4 \mathrm{~kg} \mathrm{Pu}$ Can Number Limit Exceeded,

5) Container Volume Limit Exceeded.

6) Stacking of Plutonium Bearing Containers,

7) Transport Wagon Underneath Glovebox,

8) $\mathrm{H} / \mathrm{Pu}>2$ Material Inside Glovebox,

9) Container Cluster Interaction.

10) Introduction of Water into Glovebox,

11) Water Ingress due to Fire, and

12) Seismic Concerns.

\subsection{GLOVEBOX MASS LIMIT EXCEEDED}

This mass limit applies to the entire glovebox. The mass limit is $7.5 \mathrm{~kg}$ Pu when plutonium metal is present. The mass limit is $15 . \mathrm{kg} \mathrm{Pu}$ when no plutonium metal is present. The mass limit requirement limits the plutonium metal in the form of buttons or plutonium in the form of a compound such as $\mathrm{PuO}_{2}$. This contingency, by itself, does not compromise criticality safety, but it could increase the likelihood of exceeding the $2.5 \mathrm{~kg}$ plutonium metal in a single container mass limit or the plutonium compound volume limit. Both of these items are considered separately in the calculations, so no specific calculations were deemed necessary for glovebox mass limit exceeded.

\subsection{5 KG PLUTONIUM METAL MASS CONTAINER LIMIT EXCEEDED}

This $2.5 \mathrm{~kg}$ mass limit applies to plutonium metal in individual containers. The mass limit requirements limits the plutonium metal in the form of buttons per container. This contingency, too much plutonium metal in one container, is considered in the calculations. 
WHC-SD-SQA-CSA-520 Rev. 0

\subsection{0 KG PU IN PUO ${ }_{2}$ MASS CONTAINER LIMIT EXCEEDED}

This $6.0 \mathrm{~kg} \mathrm{Pu}$ in $\mathrm{PuO}_{2}$ mass limit applies to plutonium in plutonium compounds in individual containers. The mass limit applies to plutonium in any compound, but is expected to be applied to $\mathrm{PuO}_{2}$. This contingency, too much plutonium in a plutonium compound in one container, is considered in the calculations.

\subsection{FILLED 4.4 KG PU CAN NUMBER LIMIT EXCEEDED}

The number of filled $4.4 \mathrm{~kg}$ Pu cans in the glovebox is limited to a certain number. This contingency, too many filled $4.4 \mathrm{~kg}$ Pu cans in the HC-21A glovebox, is considered in the calculations.

\subsection{CONTAINER VOLUME LIMIT EXCEEDED}

Container volume is limited and this limit could be exceeded. There are several container volumes to be considered: the Hastelloy- $X$ furnace boats at approximately 2.2 Liters, the innermost can at 1.24 Liters, the next to innermost can at 1.42 Liters, the mortar has a volume of $\approx 1$ Liter, the sieve shaker with a catch pan and one screen sieve has a calculated volume of 3.3 Liters. The sieve shaker is a special case because several interlocking tubes fit together and only the catch pan is closed on the bottom. The catch pan with diameter of $20.32 \mathrm{~cm}(8 \mathrm{in}$.) and a height of $5.08 \mathrm{~cm}$ (2 in.) calculates out to a volume of 1.65 Liters $\left(100 \mathrm{in}^{3}\right)$. The sieve shaker with a catch pan and two screen sieves has a calculated volume of 5.0 Liters. The sieve shaker with a catch pan and three screen pans has a calculated volume of 6.65 Liters. The allowed volume container is 2.5 Liters for $\mathrm{PuO}_{2}$. This contingency will be considered by calculating the reactivity of accumulations of $\mathrm{PuO}_{2}$ with $\mathrm{H} / \mathrm{Pu}=2$, to represent plutonium compounds, with volumes greater ${ }^{2}$ than the allowed container volume of 2.5 Liters for plutonium compounds.

The accumulation of plutonium metal is limited by a $2.5 \mathrm{~kg}$ Pu mass limit per container instead of a container volume limit.

\subsection{STACKING OF PLUTONIUM BEARING CONTAINERS}

Loss of geometry means putting too much plutonium metal in one container or too much plutonium compound in one container or stacking of containers with plutonium. This contingency will be considered by the same technique as the container volume limit exceeded contingency, namely by calculating the reactivity of accumulations of plutonium metal and $\mathrm{PuO}_{2}$ with volumes greater than these container volumes. This contingency is not calculated separately because the issues are considered in previously mentioned contingencies. 
WHC-SD-SQA-CSA-520 Rev. 0

\subsection{TRANSPORT WAGON UNDERNEATH GLOVEBOX}

This contingency is that a fully loaded transport wagon is driven underneath the $\mathrm{HC}-21 \mathrm{~A}$ glovebox while the glovebox is at its mass limit. The transport wagon is 17 inches wide, 35 inches long and 19.25 inches high. The five cans are in two staggered rows, with the two rows across the 17 inch width, and the staggered rows are along the 35 inch length. The plutonium bearing cans are vertically positioned such that the bottom of the cans is 10 inches above the floor and the top of the can is 17 inches above the floor. The HC-21A glovebox rests on a table frame with the glovebox floor 54 inches above the concrete floor. The top of the can is therefore $(54 \mathrm{in.}-17 \mathrm{in}=$ 37 in.) 37 inches away from the bottom the glovebox. According to documentation (WHC 1977, WHC 1994a) the table frame support has horizontal cross members positioned at 6 inches to 10 inches above the floor, and again about 20 inches above that. There are horizontal cross members on the sides and on the ends. This structure has been designed for structural stability. This contingency is addressed.

\section{$8.8 \mathrm{H} / \mathrm{PU}>2$ MATERIAL INSIDE GLOVEBOX}

One way that the contingency of loss of moderation control was considered is by calculating the $\mathrm{PuO}_{2}$ with a $\mathrm{H} / \mathrm{Pu}>2$. Higher concentrations of water than $\mathrm{H} / \mathrm{Pu}=2$ will be noticeable and not appear dry. The 14 hour furnace burn as well as the LOI test makes the $\mathrm{H} / \mathrm{Pu}>2$ concentration very unlikely. The situations of concern are: (1) that moderated material can be introduced from clean out activities and placed in the furnace boats, and (2) that flooding could occur due to some catastrophic failure.

The flooding and mixing with water portion of this contingency has already been considered in Section 6.0 that covered plutonium at al1 moderations and water reflections with different mass and volume constraints. This contingency was addressed by considering all of these of situations, loss of moderation control, introduction of water. and the water ingress due to fire (flooding) cases together.

\subsection{CONTAINER CLUSTER INTERACTION}

There are spacing controls of $25 \mathrm{~cm}$ (10 in.) between groups of containers for separate operations. These separate operations are:

- Pouring Furnace Boat $\mathrm{PuO}_{2}$ into Sieve Shaker Screen and Pan,

- $\quad \mathrm{PuO}_{2}$ Grinding and Sieving Operation,

- Can Filling Operation.

- Storing Unsealed Can and Sealing Can with Lid, and

- Sealing Can Inside a Second Can and Sphincter Port Exit.

The main feature of these separate operations is keeping the $4.4 \mathrm{~kg} \mathrm{Pu}$ can separate from the other plutonium containers. This contingency will be considered as getting the $4.4 \mathrm{~kg}$ Pu can close to the furnace boat and more than one can adjacent to the sieve shaker pan. 
WHC-SD-SQA-CSA-520 Rev. 0

\subsection{INTRODUCTION OF WATER INTO GLOVEBOX}

Glovebox HC-21A is designated as a DRY glovebox and there are no liquid lines running through this glovebox. There are three ways to introduce moderation: 1) catastrophic: breakage of plastic glovebox panels concurrently with room and water sprinklers introducing water, 2) contingency: introduction of containers with moderating liquid, and 3) routine: introduction of objects that can cause a moderating effect, such as human hand and arms inside rubber gloves. Calculations considered, as part of the normal situation with nominal reflection, one inch of water reflection around individual containers to conservatively model human hands moving containers around.

The situation of introduction of water into the glovebox has already been covered in Section 6.0 that covered plutonium at all moderations and water reflections with different mass and volume constraints. This contingency was addressed by considering all of these of situations. loss of moderation control, introduction of water, and the water ingress due to fire (flooding) cases together.

\subsection{WATER INGRESS DUE TO FIRE}

This situation involves roof sprinklers spraying on this glovebox which had the roof plastic break such that water can enter the glovebox and collect in containers. Because the glovebox is open to a conveyor, there is not the concern for the glovebox flooding.

The situation of water ingress due to fire has already been covered in Section 6.0 that covered plutonium at a 11 moderations and water reflections with different mass and volume constraints. This contingency was addressed by considering all of these of situations, loss of moderation control, introduction of water, and the water ingress due to fire (flooding) cases together.

\subsection{SEISMIC CONCERNS}

This situation involves tipping a non-seismically qualified glovebox such that all fissile material is collected together. This contingency is considered separately in Section 9.2.12.

\subsection{EVALUATION AND RESULTS}

The computer calculation evaluation took two separate approaches, one is modeling of the HC-21A glovebox in normal and off-normal situations, and the other was a parametric study of material expected inside the glovebox. The normal and off-normal MONK6B results are listed in Table 9.1 and were used to set the $\mathrm{HC}-21 \mathrm{~A}$ glovebox mass limits subject to administrative controls. The parametric study, 1isted in Table 9.2, was used to determine the mass 1imits possible with no administrative controls. 


\subsection{NORMAL CONDITIONS}

Because of the multiple uses for glovebox HC-21A in support of the muffle furnace operation, it was useful to consider three situations individua17y: (1) plutonium metal buttons in furnace boats before heating in the furnace, (2) sieving and pouring into open cans, and (3) open cans being closed after the confirmation of dryness tests (LOI) are performed.

The glovebox dimensions and conditions outside the glovebox are identical for these three situations and for all normal and off-normal conditions listed in Table 9.1. The containers inside the glovebox have some close fitting water reflector, $2.54 \mathrm{~cm}$ (1 in.) or larger depending on the geometry being surrounded. The glovebox inside is modelled as air filled. The container collection is placed adjacent to one corner of the glovebox for maximum reflection off the glovebox walls. The glovebox is modeled as $0.635 \mathrm{~cm}(0.25 \mathrm{in.})$ of 304 stainless steel. The standard outside glovebox configuration uses air space below the glovebox for the $137.16 \mathrm{~cm}$ (54 in.) distance down to the top of the concrete floor. Immediately outside the glovebox is $30.00 \mathrm{~cm}$ (12 in.) of water reflector on all sides of the glovebox up to the glovebox roof. Immediately outside this water reflector is $30.00 \mathrm{~cm}$ (12 in.) of air space on a17 sides of the water reflector up to the glovebox roof. Finally is $20 \mathrm{~cm}$ ( 8 in.) of concrete below this glovebox model.

The different cases depended on the plutonium loading within the glovebox and the different containers.

\subsubsection{Preparation of Plutonium for Furnace Burning}

Three plutonium metal buttons, each assumed to be $2.5 \mathrm{~kg}$, are placed into separate Hastelloy- $X$ furnace boats. These boats are modeled as being side by side with the plutonium metal buttons centered in each Hastelloy- $x$ boat. $2.54 \mathrm{~cm}$ ( $1 \mathrm{in}$.) of water reflection is assumed to be present on radial sides and on the top of each of the plutonium buttons simulating rubber gloved hands.

The nominal situation of three furnace boats with a $2.5 \mathrm{~kg}$ of plutonium metal button in each. HC21AA1 had a $k_{\text {eff }}=0.7633 \pm 0.0029$. The series of MONK6B calculations modeling the plutonium metal buttons in furnace boats is the HC21AA series 1isted in Table 9.1. Case HC21AA6, with $k_{\text {eff }}=0.9268 \pm$ 0.0033 , had $5 \mathrm{~kg}$ plutonium in each furnace boat, a single contingency situation for each of 3 boats. That is 3 contingencies of double batching. Al1 HC21AA series cases, many of which represent multiple contingencies of double batching (two $2.5 \mathrm{~kg}$ buttons), spacing (more than 3 boats together), stacking ( 3 boats on top of 3 boats), and overbatching (more than $7.5 \mathrm{~kg}$ metal in the glovebox). had $k_{\text {eff }}$ less than 0.935 . 
Table 9.1 HC-21A Normal and Off-Normal MONK6B Results.

$\mathrm{PuO}_{2}$ with $\mathrm{Pu} 5.5 \mathrm{~g} / \mathrm{cm}^{3}$ and Hydrogen $/ 239 \mathrm{Pu}=2$

2.5 Kilogram Metal Buttons

Nominal Reflection is 1 Inch water on Sides and Top

\begin{tabular}{|c|c|c|c|c|c|}
\hline Case \# & $\begin{array}{l}\text { Pu Metal } \\
\text { in Boats }\end{array}$ & $\begin{array}{l}\text { Sieve } \\
\text { Stack }\end{array}$ & $\begin{array}{l}\mathrm{PuO}_{2} \text { in } \\
\mathrm{Cans}\end{array}$ & $\begin{array}{l}\mathrm{PuO}_{2} \text { on } \\
\mathrm{GB}+1 \text { oor }\end{array}$ & $\frac{\text { RESULTS }}{\mathrm{k}_{\text {eff }} \pm \sigma}$ \\
\hline \begin{tabular}{|l|} 
HC21AA1 \\
\end{tabular} & $3 @ 2.5 \mathrm{~kg}$ & & & & $0.7633 \pm 0.0029$ \\
\hline $\begin{array}{l}\text { HC21AA2 } \\
\end{array}$ & $602.5 \mathrm{~kg}$ & & & & $0.7646 \pm 0.0029$ \\
\hline \begin{tabular}{|l} 
HC21AA3 \\
\end{tabular} & $3 @ 2.5 \mathrm{~kg}$ & & & $0.125^{\prime \prime}$ & $0.7736 \pm 0.0037$ \\
\hline \begin{tabular}{|l|} 
HC21AA4 \\
\end{tabular} & 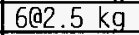 & & & $0.125^{\prime \prime}$ & $0.7875 \pm 0.0034$ \\
\hline \begin{tabular}{|l} 
HC21AA5 \\
\end{tabular} & 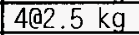 & & & & $0.7718 \pm 0.0028$ \\
\hline HC21AA6 & $305.0 \mathrm{~kg}$ & & & & $0.9268 \pm 0.0033$ \\
\hline HC21AA7 & $\begin{array}{l}3 \mathrm{~d} 2.5 \mathrm{~kg} \\
5 \mathrm{~kg} \text { PuO }\end{array}$ & & & & $0.8022 \pm 0.0036$ \\
\hline HC21AA8 & $302.5 \mathrm{~kg}$ & .651 & & & $0.7808 \pm 0.0033$ \\
\hline $\begin{array}{l}\text { HC21AA9 } \\
\end{array}$ & $3 \AA 2.5 \mathrm{~kg}$ & & $4 @ 5 \mathrm{~kg}$ & & $0.9255 \pm 0.0033$ \\
\hline \begin{tabular}{|l} 
HC21AAA \\
\end{tabular} & $602.5 \mathrm{~kg}$ & & & & $0.8844 \pm 0.0030$ \\
\hline HC21AAB & $\begin{array}{l}302.5 \mathrm{~kg} \text {. } \\
5 \mathrm{~kg} \mathrm{PuO}\end{array}$ & & & & $0.8799 \pm 0.0039$ \\
\hline HC21AB1 & & 1.65 & & & $0.6899 \pm 0$ \\
\hline $\begin{array}{l}\text { HC21AB2 } \\
\end{array}$ & & 3.291 & & & $0.9584 \pm 0.0033$ \\
\hline \begin{tabular}{|l}
$\mathrm{HC} 21 \mathrm{AB} 3$ \\
\end{tabular} & & $4.94 \mathrm{~L}$ & & & $1.1084 \pm 0.0036$ \\
\hline \begin{tabular}{|l|} 
HC21AB4 \\
\end{tabular} & & 6.59 & & & $1.1783 \pm 0.0037$ \\
\hline HC21AB5 & & 1.65 & $305 \mathrm{~kg}$ & & $0.9170 \pm 0.0033$ \\
\hline \begin{tabular}{|l}
$\mathrm{HC} 21 \mathrm{AB} 6$ \\
\end{tabular} & & 1.65 & 3 a $5 \mathrm{~kg}$ & $0.125^{\prime \prime}$ & $0.9378 \pm 0.0036$ \\
\hline \begin{tabular}{|l|} 
HC21ACl \\
\end{tabular} & & & $305 \mathrm{~kg}$ & & $0.9081 \pm 0.0033$ \\
\hline \begin{tabular}{|l}
$\mathrm{HC} 21 \mathrm{AC} 2$ \\
\end{tabular} & & & $405 \mathrm{~kg}$ & & $1.0140 \pm 0.0036$ \\
\hline HC21AC3 & & & $5 @ 5 \mathrm{~kg}$ & & $1.0512 \pm 0.0035$ \\
\hline HC21AC4 & & & $605 \mathrm{~kg}$ & & $1.0887 \pm 0.00$ \\
\hline HC21AC5 & & & 7 @ $5 \mathrm{~kg}$ & & $1.1319 \pm 0.0035$ \\
\hline HC21AC6 & & & $305 \mathrm{~kg}$ & $0.125^{\prime \prime}$ & $0.9226 \pm 0.0038$ \\
\hline HC21AC7 & & & $405 \mathrm{~kg}$ & 0.125 & $1.0300 \pm 0.0038$ \\
\hline $\begin{array}{l}\text { HC21AC8 } \\
\end{array}$ & & & $505 \mathrm{~kg}$ & $0.125^{\prime \prime}$ & $1.0712 \pm 0.0038$ \\
\hline $\begin{array}{l}\text { HC21AC9 } \\
\end{array}$ & & & $605 \mathrm{~kg}$ & $0.125^{\prime \prime}$ & $1.1006 \pm 0.0038$ \\
\hline HC21ACA & & & $705 \mathrm{~kg}$ & $0.125^{\prime \prime}$ & $1.1443 \pm 0.00$ \\
\hline
\end{tabular}

The contingencies included $5 \mathrm{~kg} \mathrm{PuO} 2$ powder in each of three boats with the $2.5 \mathrm{~kg}$ button which was case HC21AA7. Addition of water inside the furnace boat up to the brim is the additional contingency in HC21AAB that distinguishes it from HC21AA7. Additional contingencies considered 3 loaded boats with an $0.3175 \mathrm{~cm}\left(0.125 \mathrm{in}\right.$.) layer of $\mathrm{PuO}_{2}$ on the glovebox floor, or with four $4.4 \mathrm{~kg}$ Pu cans with $5 \mathrm{~kg} \mathrm{Pu}$ in each, or with a full sieve pan, and 6 loaded boats in a single layer with an $0.3175 \mathrm{~cm}\left(0.125 \mathrm{in}\right.$.) layer of $\mathrm{PuO}_{2}$ on the glovebox floor, and 6 loaded boats of 3 in a double layer. In a11 the mentioned cases, the $k_{\text {eff }}$ remained less than 0.935 . 


\subsubsection{Transfer of Plutonium Oxide into 4.4 Kilogram Cans}

$\mathrm{PuO}_{2}$ is present in Hastelloy-X furnace boats, in the screen pan and catch pan sieve shaker, and in the innermost of the $4.4 \mathrm{~kg}$ Pu cans. No plutonium metal is allowed to be present. $2.54 \mathrm{~cm}(1 \mathrm{in.})$ of water reflection is assumed to be present on the top and around the outermost surface of the cluster of plutonium bearing containers simulating rubber gloved hands. Calculations focussed on the effect of loading the sieve shaker assembly with $\mathrm{PuO}_{2}$.

The volume of the sieve shaker pan alone is not larger than the 2.5 Liter volume permitted according to the administratively controlled features. When sieve screens are added, then the volume can exceed the 2.5 Liter volume, so it is relevant to calculate the plutonium mass in the sieve shaker model calculated in the HC21AB series, 1isted in Table 9.1. The conversions from volume to mass assumes $5.5^{-} \mathrm{g} \mathrm{Pu} / \mathrm{cm}^{3}$.

$$
\begin{aligned}
& \pi / 4 *(8 \text { in. })^{2} *(2 \text { in. }+0 * 2 \text { in. })=101 \text { in. }^{3} \Rightarrow 1.65 \text { Liters } \Rightarrow 9.06 \mathrm{~kg} \text { Pu. } \\
& \pi / 4 *(8 \text { in. })^{2} *(2 \text { in. }+1 * 2 \text { in. })=201 \text { in. }^{3} \Rightarrow 3.29 \text { Liters } \Rightarrow 18.1 \mathrm{~kg} \mathrm{Pu} \text {, } \\
& \left.\Pi / 4 *(8 \text { in. })^{2 *(2 ~ i n . ~}+2 * 2 \text { in. }\right)=302 \text { in. }^{3} \Rightarrow 4.94 \text { Liters } \Rightarrow 27.2 \mathrm{~kg} \mathrm{Pu} \text {, and } \\
& \pi / 4 *(8 \text { in. })^{2} *(2 \text { in. }+3 * 2 \text { in. })=402 i n^{3} \Rightarrow 6.59 \text { Liters } \Rightarrow 36.2 \mathrm{~kg} \text { Pu. }
\end{aligned}
$$

The above mass quantities explain the unrealistically high $k_{\text {eff }}$ 's for cases HC21AB2, HC21AB3 and HC21AB4. This also provides the bas is for a $6.0 \mathrm{~kg}$ $\mathrm{Pu}$ in $\mathrm{PuO}_{2}$ mass limit for single containers. The closest to a nominal situation, one full sieve shaker pan with 3 filled cans, although with extra plutonium and partial water reflection, case HC21AB5 had a $k_{\text {eff }}=0.9170 \pm$ 0.0033 .

Case HC21AB6 with a sieve pan, three $4.4 \mathrm{~kg}$ cans and a $0.3175 \mathrm{~cm}$ ( 0.125 in.) $\mathrm{PuO}_{2}$ layer on the glovebox floor exceeds the allowed $\mathrm{k}_{\text {eff }}$ of 0.935 with a value of 0.938 . Thus spills of $\mathrm{PuO}_{2}$ must be cleaned up between each incident of a loaded sieve pan being brought to fill a $4.4 \mathrm{~kg}$ Pu can.

\subsubsection{Sealing of Plutonium 0xide in 4.4 Kilogram Cans}

$\mathrm{PuO}_{2}$ is present in the innermost of the $4.4 \mathrm{~kg}$ Pu cans (convenience can), and the next innermost can (inner can) is also present for double canning the $\mathrm{PuO}_{2}$ before it is bagged out of the $\mathrm{HC}-21 \mathrm{~A}$ glovebox. No plutonium metal is allowed to be present. $2.54 \mathrm{~cm}$ (1 in.) of water reflection is assumed to be present on the top and around the outermost surface of the cluster of plutonium bearing containers simulating rubber gloved hands. 
Different numbers of filled cans clustered together and water reflector with at least $2.54 \mathrm{~cm}(1$ in. $)$ thickness were considered. The HC21AC series reported in Table 9.1 records the calculations for clustered cans. The maximum number of $4.4 \mathrm{~kg}$ Pu cans that can be clustered with $\mathrm{k}_{\text {eff }}<0.935$ is three. This also provides a basis for a glovebox total plutonium of $15 \mathrm{~kg}$ plutonium. The single contingency situation, three full plutonium storage cans, although with extra plutonium $(5 \mathrm{~kg}$ Pu modeled rather than the nominal $4.4 \mathrm{~kg} \mathrm{Pu}$ loading) and partial water reflection, case HC21AC1 had a $\mathrm{k}_{\text {eff }}=$ $0.9081 \pm 0.0033$. Note that four cans $k_{\text {eff }}$ exceeds 1.0 . A second contingency of four cans with $20 \mathrm{~kg}$ is calculated to go critical. Fortunately, only two hands could not give sufficient neutron reflection for so many cans, so there is conservatism in this calculation. Still these contingency calculations point out the care that must be exercised with this much $\mathrm{Pu}$ in $\mathrm{PuO}_{2}$ in a can.

\subsection{OFF-NORMAL CONDITIONS}

For off-normal conditions the following contingencies were considered for MONK6B calculations:

1) Glovebox Mass Limit Exceeded.

2) $2.5 \mathrm{~kg}$ Plutonium Metal Mass Container Limit Exceeded,

3) $6.0 \mathrm{~kg} \mathrm{Pu}$ in $\mathrm{PuO}_{2}$ Mass Container Limit Exceeded,

4) Filled $4.4 \mathrm{~kg}$ Pu Can Number Limit Exceeded,

5) Container Volume Limit Exceeded,

6) Stacking of Plutonium Bearing Containers,

7) Transport Wagon Underneath Glovebox,

8) H/Pu>2 Material Inside Glovebox.

9) Container Cluster Interaction.

10) Introduction of Water into Glovebox,

11) Water Ingress due to Fire, and

12) Seismic Concerns.

\subsubsection{Glovebox Mass Limit Exceeded}

This contingency, by itself, does not compromise criticality safety, but it could increase the likelihood of exceeding the $2.5 \mathrm{~kg}$ plutonium metal in a single container mass limit or the plutonium mass limit for a single container. Both of these items are considered in the calculations, so no specific calculations were performed for exceeding the glovebox mass limit.

\subsection{2 $2.5 \mathrm{~kg}$ Plutonium Metal Mass Container Limit Exceeded}

This contingency, too much plutonium metal in one container, is considered in case HC21AA6 with $5.0 \mathrm{~kg}$ pu metal in each of three furnace boats which had a $k_{\text {eff }}=0.9268 \pm 0.0033$. This calculation is conservative because the two plutonitum buttons were modeled as a cylinder $3.632 \mathrm{~cm}(1.430 \mathrm{in}$.) radius and $6.20 \mathrm{~cm}(2.441 \mathrm{in}$.) high for a total mass of:

$$
\pi(3.632 \mathrm{~cm})^{2} *(6.20 \mathrm{~cm}) * 19.464 \mathrm{~g} \mathrm{Pu} / \mathrm{cm}^{3}=5,001.1 \mathrm{~g} \mathrm{Pu} \text {. }
$$


This plutonium mass is twice 2,500 grams, which is larger than any single plutonium metal button. The water reflection was modeled as another cylinder $6.172 \mathrm{~cm}$ (2.43 in.) radius for a water thickness of $2.54 \mathrm{~cm}$ (1 in.) on the sides and on the top of this cylinder.

The plutonium mass limit could also be exceeded by spilling a container of $5 \mathrm{~kg} \mathrm{Pu}$ in $\mathrm{PuO}_{2}$ into a furnace boat. Case $\mathrm{HC} 21 \mathrm{AA} 7$, with $2.5 \mathrm{~kg}$ plutonium metal and $5 \mathrm{~kg}$ in $\mathrm{PuO}_{2}$ in each of three furnace boats, had a $\mathrm{k}_{\text {eff }}=0.8022 \pm$ 0.0036 . This illustrates that double batching metal systems is more reactive that double batching metal and $\mathrm{PuO}_{2}$ systems. Both of these cases did not exceed the criticality safety limit of 0.935 .

\subsubsection{0 kg Pu in $\mathrm{PuO}_{2}$ Mass Container Limit Exceeded}

The mass accumulation in a container is considered in the sieve shaker system because this system is the only container that exceeds the volume limit of 2.5 Liters for any container in glovebox $\mathrm{HC}-21 \mathrm{~A}$. The volume of the sieve shaker pan alone is not larger than the 2.5 Liter volume permitted according to the administratively controlled features. When sieve screens are added, then the volume can exceed the 2.5 Liter volume, so it is relevant to calculate the plutonium mass in the sieve shaker model calculated in the $\mathrm{HC} 21 \mathrm{AB}$ series listed in Table 9.1. The conversions from volume to mass assume $\bar{s} 5.5 \mathrm{~g} \mathrm{Pu} / \mathrm{cm}^{3}$.

$$
\begin{aligned}
& \pi / 4 *(8 \text { in. })^{2} *(2 \text { in. }+0 * 2 \text { in. })=101 \text { in. }^{3} \Rightarrow 1.65 \text { Liters } \Rightarrow 9.06 \mathrm{~kg} \mathrm{Pu} \\
& \pi / 4 *(8 \text { in. })^{2} *(2 \text { in. }+1 * 2 \text { in. })=201 \text { in. }^{3} \Rightarrow 3.29 \text { Liters } \Rightarrow 18.1 \mathrm{~kg} \mathrm{Pu} \\
& \pi / 4 *(8 \text { in. })^{2}(2 \text { in. }+2 * 2 \text { in. })=302 \text { in. }^{3} \Rightarrow 4.94 \text { Liters } \Rightarrow 27.2 \mathrm{~kg} \mathrm{Pu} \text {, and } \\
& \pi / 4 *(8 \text { in. })^{2} *(2 \text { in. }+3 * 2 \text { in. })=402 \text { in. }^{3} \Rightarrow 6.59 \text { Liters } \Rightarrow 36.2 \mathrm{~kg} \mathrm{Pu} \text {. }
\end{aligned}
$$

The above mass quantities explain the $k_{\text {eff }}$ 's for cases HC21AB1 (1.65 L, $\left.9.06 \mathrm{~kg} \mathrm{Pu}, \mathrm{K}_{\text {fff }}=0.6899 \pm 0.0030\right), \mathrm{HC} 21 \mathrm{AB} 2\left(3.29 \mathrm{~L}, 18.1 \mathrm{~kg} \mathrm{Pu}, \mathrm{K}_{\text {fff }}=\right.$ $0.9584 \pm 0.0033)$. HC21AB3 $\left(4.94 \mathrm{~L}, 27.2 \mathrm{~kg} \mathrm{Pu} . \mathrm{K}_{\text {eff }}=1.1084 \pm 0.0036\right)$ and HC21AB4 $\left(6.59 \mathrm{~L}, 36.2 \mathrm{~kg} \mathrm{Pu}, \mathrm{k}_{\text {fff }}=1.1783 \pm 0.0037\right)$. This provides the basis for a container mass 1 imit of $b^{f f} .0 \mathrm{~kg} \mathrm{Pu}$ in plutonium compounds. This $6.0 \mathrm{~kg}$ Pu mass limit for single containers is lower than the case HC21ABl, which represents a single contingency with $9.06 \mathrm{~kg} \mathrm{Pu}$, with $\mathrm{k}_{\text {eff }}=0.6899 \pm 0.0030$ and shows that this single contingency does not exceed the criticality safety Timit of 0.935 . The normal boat loading is $2.5 \mathrm{~kg} \mathrm{Pu}$. Adding an extra boat load to the $6.0 \mathrm{~kg}$ Pu limit for a container would be one contingency resulting in $8.5 \mathrm{~kg}$ Pu which is less than the calculated $9.06 \mathrm{~kg} \mathrm{Pu}$. Interpolating between $\mathrm{k}_{\text {eff }}$ 's for HC21AB1 and HC21AB2, even a second contingency of $2.5 \mathrm{~kg}$ more $\mathrm{Pu}$ in $\mathrm{PuO}_{2}$ would not exceed the safety limit of 0.935 . However, the rapid change in reactivity with plutonium addition should be noted to prevent exceeding the $6.0 \mathrm{~kg}$ plutonium mass limits in a single container. 
WHC-SD-SQA-CSA-520 Rev. 0

\subsubsection{Filled 4.4 kg Pu Can Number Limit Exceeded}

This situation was modeled with series HC21AC and considered different numbers of $4.4 \mathrm{~kg}$ Pu cans clustered tightly together and reflected by a minimum of $2.54 \mathrm{~cm}$ ( $1 \mathrm{in}$.) of $\mathrm{H}_{2} \mathrm{O}$. Each $4.4 \mathrm{~kg}$ Pu can was modeled with $5.0 \mathrm{~kg}$ of $\mathrm{Pu}$ in $\mathrm{PuO}$, with $\mathrm{H} / \mathrm{Pu}=2$ and a density of $5.5 \mathrm{~g} \mathrm{Pu} / \mathrm{cm}^{3}$. Case HC21AC6, with only three (3) $4.4 \mathrm{~kg}$ Pu cans, had $\mathrm{k}_{\text {fff }}=0.9226 \pm 0.0038$ does not exceed the criticality safety limit of 0.935 . This defines three (3) filled $4.4 \mathrm{~kg} \mathrm{Pu}$ cans as being a single contingency case where the can number limit was exceeded. This result sets the limit on the number of $4.4 \mathrm{~kg}$ Pu cans in $\mathrm{HC}-21 \mathrm{~A}$ to be two (2).

Case HC21AC2 with four filled $4.4 \mathrm{~kg}$ Pu cans adjacent and with at least $2.54 \mathrm{~cm}$ (1 in.) of water reflection on all radial sides and on top, calculates a $k_{\text {eff }}$ of $1.0140 \pm 0.0036$ (Prompt Critical!). Enough emphasis cannot be placed on the requirement for strict procedural checks on the number of adjacent $4.4 \mathrm{~kg}$ Pu cans.

\subsubsection{Container Volume Limit Exceeded}

Container volume is limited 2.5 Liters and this limit could be exceeded. The sieve shaker with a catch pan and one, two, or three screen sieves was considered in HC21AB1, HC21AB2, HC21AB3, HC21AB4. The conclusion is that all but the sieve pan alone are unsafe volumes, but that the glovebox mass limit of $15 \mathrm{~kg}$ Pu does not permit accumulation of plutonium to the volumes calculated in this series of calculations.

A filled to the brim screen pan, with a volume of 1.65 Liters $\left(100 \mathrm{in}^{3}\right)$ and $\mathrm{PuO}_{2}$ at a density of $5.5 \mathrm{~g} \mathrm{Pu} / \mathrm{cm}^{3}$ is a mass of $9.06 \mathrm{~kg} \mathrm{Pu}$. This mass is considered to be a contingency because the limit of $6.0 \mathrm{~kg} \mathrm{Pu}$ in $\mathrm{PuO}_{2}$ per container is exceeded. This calculation mimics exceeding the $2.5 \mathrm{Liter}$ volume limit for $\mathrm{PuO}_{2}$ containers. This case, $\mathrm{HC} 21 \mathrm{AB} 1$, has $\mathrm{k}_{\text {ff }}=0.6899 \pm 0.0030$ which is below the allowable 0.935 . The multiple contingency case with 3 cans filled with $\mathrm{PuO}_{2}$ ( $5 \mathrm{~kg}$ Pu each totalling $15 \mathrm{~kg}$ ) next to a filled sieve pan, $\mathrm{HC21AB5}$, has a $k_{\text {eff }}=0.9170 \pm 0.0033$ and shows that this multiple contingency does not exceed the criticality safety limit of 0.935 .

\subsubsection{Stacking of Plutonium Bearing Containers}

Stacking of containers with plutonium was considered for the case of plutonium metal buttons in furnace boats. This had been calculated previously by Hess $(1996 \mathrm{c})$. Because water reflection inside the glovebox was not considered by Hess (Hess 1996c), this contingency was calculated again with $2.54 \mathrm{~cm}$ (1 in.) of $\mathrm{H}_{2} 0$. Case HC21AA4 with 6 furnace boats, $2.5 \mathrm{~kg} \mathrm{Pu}$ each, in a two rows of 3 furnace boats had a $k_{\text {eff }}=0.7875 \pm 0.0034$. Case HC21AAA with 6 furnace boats, $2.5 \mathrm{~kg}$ Pu each, double stacked as one row of 3 contiguous furnace boats had a $k_{\text {eff }}=0.8844 \pm 0.0030$ shows that this double stacking is more reactive. This multiple contingency $(15.0 \mathrm{~kg}$ Pu metal, spacing errors) with a $k_{\text {eff }}=0.8844 \pm 0.0030$ does not exceed the criticality safety limit of 0.935 . 
WHC-SD-SQA-CSA-520 Rev. 0

\subsubsection{Transport Wagon Underneath Glovebox}

This contingency is that a fully loaded transport wagon is driven underneath the $\mathrm{HC}-21 \mathrm{~A}$ glovebox while the glovebox is at its mass limit. The transport wagon carrying five cans of $4.4 \mathrm{~kg} \mathrm{Pu}$ is the form of $\mathrm{PuO}_{2}$ could not be rolled under the glovebox from any side. The distance from the top of the $4.4 \mathrm{~kg} \mathrm{Pu}$ cans is (54 in. $-17 \mathrm{in.}=37 \mathrm{in})$.37 inches vertical distance from the bottom the glovebox. This distance will cause the position of the transport wagon adjacent to the glovebox to have a very small effect in comparison to conditions inside the glovebox.

This contingency was calculated by Erickson (1996) for a much more reactive situation, the wagon in Vault \#2 where the wagon is on the same Tevel as the $4.4 \mathrm{~kg} \mathrm{Pu}$ storage cans. The calculated normal case $(\mathrm{V}-\mathrm{N}-02-\mathrm{A}) \mathrm{k}_{\text {eff }}$ was raised from $0.830 \pm 0.003$ to the adjacent wagon contingency case $(\mathrm{V}-\mathrm{C}-3 \mathrm{I}-\mathrm{A})$ $k_{\text {ff }}$ of $0.837 \pm 0.003$. This calculated model had the wagon cans touching three of the storage rack cans while adjacent to the concrete floor. Each $4.4 \mathrm{~kg} \mathrm{Pu}$ can was modeled with $4.5 \mathrm{~kg} \mathrm{Pu}$ in $\mathrm{PuO}_{2}$ with $\mathrm{H} / \mathrm{Pu}=2$. The wagon under the glovebox contingency, with an edge-to-edge spacing of 37 inches would have a much reduced effect on $k_{\text {eff }}$ than this bounding MONK6B calculation which showed a $7 \mathrm{mk}$ increase in reactivity. Therefore, it can be stated, this single contingency of a transport wagon, carrying five $4.4 \mathrm{~kg}$ Pu cans, underneath the $\mathrm{HC}-21 \mathrm{~A}$ glovebox does not exceed the criticality safety limit of 0.935 .

\subsubsection{H/Pu>2 Material Inside Glovebox}

The criticality safety of the full range of $\mathrm{H} / \mathrm{Pu}$ material was considered in section 6.0 The basic argument is that at low $\mathrm{H} / \mathrm{Pu}$ rations, criticality is unlikely due to the high required mass, while at higher $\mathrm{H} / \mathrm{Pu}$ ratios, criticality is unlikely due to high required container volume. At low water dilution, a large mass, approaching or exceeding the entire allowed glovebox inventory of $15 \mathrm{~kg} \mathrm{Pu}$ is required for criticality. The argument continued that at higher water dilution, the mass required for criticality diminishes. but the necessary volume for criticality is greater than the allowed total of clustered container volumes.

\subsubsection{Container Cluster Interaction}

There is a $25 \mathrm{~cm}$ (10 in.) spacing requirement between different, operation based, clusters of containers. These clusters of containers are set in the administrative limits to be:

- Pouring Furnace Boat PuO into Sieve Shaker Screen and Pan,

- $\quad \mathrm{PuO}_{2}$ Grinding and Sieving Operation.

- Can Filling Operation.

- Storing Unsealed Can and Sealing Can with Lid, and

- Sealing Can Inside a Second Can and Sphincter Port Exit.

The main feature of these separate operations is keeping the $4.4 \mathrm{~kg} \mathrm{Pu}$ can separate from the other plutonium containers. This contingency will be considered as getting the $4.4 \mathrm{~kg}$ Pu can close to the furnace boat and more than one can adjacent to the sieve shaker pan. 
The situation of $4.4 \mathrm{~kg}$ cans close to furnace boats is bounded by the calculation of case HC21AA9. Case HC21AA9 had 3 furnace boats with centered $2.5 \mathrm{~kg} \mathrm{Pu}$ buttons side by side and adjacent to a 7 ine of four $4.4 \mathrm{~kg} \mathrm{Pu}$ cans. which represented multiple contingencies, and had a calculated $k_{\text {eff }}$ of 0.9255 \pm 0.0033 , which is still below the criticality safety limit for a single contingency of 0.9350 .

The situation of $4.4 \mathrm{~kg}$ cans close to the sieve pan is bounded by the calculation of case HC21AB5. Case HC21AB5 had the sieve pan with $9.06 \mathrm{~kg}$ of $\mathrm{Pu}$ in $\mathrm{PuO}_{2}$, in itself a multiple contingency, tangent to three $4.4 \mathrm{~kg} \mathrm{Pu}$ cans. which also represents a multiple contingency, and had a calculated $k_{\text {eff }}$ of $0.9170 \pm 0.0033$, which is still below the criticality safety limit for a single contingency of 0.9350 .

These two cases bound the effect of interaction and demonstrate that criticality safety is not compromised with the occurrence of this single contingency, but that another, additional and concurrent, contingency would have to occur before criticality safety would become compromised.

\subsubsection{Introduction of Water into G1ovebox}

Glovebox HC-21A is designated as a DRY glovebox and there are no liquid lines running through this glovebox. The contingency of introduction of small amount of water into glovebox $\mathrm{HC}$-21A was already calculated in the normal cases because a standard $2.54 \mathrm{~cm}$ ( 1 in.) of water reflection was assumed around the plutonium. Section 6.0 covered plutonium at all moderations and water reflections with different mass and volume constraints. This contingency was addressed by considering all three situations, loss of moderation control, introduction of water, and the water ingress due to fire (flooding) cases together.

\subsubsection{Water Ingress Due to Fire}

The furnace support glovebox, HC-21A, is also designated as a "DRY" glovebox, so no water or chemical solution pipelines are within the box and there may be only very limited volumes of water in containers. This design feature and this CSER restriction on maximum material moisture content substantially limit the degree of moderation and reflection of the fissile medium to be expected as normal. It is possible for water to be introduced in the event of a fire inside or near the glovebox, due to overhead room sprinklers or firefighter-directed streams. Based on years of operational history, however, the probability for this scenario is exceedingly low. Conformance with the "double contingency" principle, therefore, requires only that with any plausible normal. no-error arrangement of fissile-bearing containers in the glovebox a criticality could not result due to water ingress.

Glovebox HC-21A opens on one end into a conveyor glovebox, so that for the water ingress incident supposed above the depth of flooding on this glovebox floor would be minimat, certainly not enough to render a full reflection condition above plutonium containers arrayed on the floor. 
With the containers being as flat open top boats, however, there is the potential for water dilution of the fissile-bearing material to $\mathrm{H} / \mathrm{Pu}>2$. If the water ingress occurs as a spray or overhead "rain". the fissile material is not expected to be disturbed, and will occupy its original volume fraction, or it could slump to a greater concentration by the wetting action. For the sake of the safety assurance argument, however, we will assume the maximum reactivity dilution is achieved, by filling the container with a uniform $\mathrm{PuO}_{2}$ water mixture with the allowed mass and volume for the container. But to get. $2500 \mathrm{~g} \mathrm{Pu}$ per boat in a large array critical with only nominal reflection requires water dilution to a depth of $9.1 \mathrm{~cm}$ (3.6 inches) (Hess 1996c), which by overflowing would render this an unrealistic situation.

Hess (1996c) did consider criticality to be possible with between $350 \mathrm{~g}$ $\mathrm{Pu}$ and $2500 \mathrm{~g} \mathrm{Pu}$ per boat in an boat array without overfilling, but to achieve the full reflection condition below the glovebox floor, as well as the flooding depth above the boats was not considered to be credible. Movement of the loaded boats due to any plausible water stream impact is very unlikely due to the gross weights of these containers.

\subsubsection{Seismic Concerns}

Similar to the fire-water ingress event, conformance with the "double contingency" principle requires that with any plausible norma?, no-error arrangement of fissile-bearing containers in the glovebox a criticality could not result from the agitation and damage from an earthquake. The most likely scenario would have the Pu-bearing boat materials being spilled out and scattered over a larger area so as to be less reactive. Furnace support glovebox $\mathrm{HC}-21 \mathrm{~A}$ is not seismically qualified, so there is the prospect for tilting of the floor. due to fracture or bending of the box support table legs.

In a tilted situation material would tend to sift down to a lower end or corner of the glovebox. Ignoring the structural impediments for full drifting throughout the glovebox length, a11 the allowed Pu inventory of $15 \mathrm{~kg}$ formed as a triangular wedge at the end of the box would not be critical (Hess $1996 \mathrm{c}$ ). This is also possible to glean from Table 9.4, 15.0 Kilogram Plutonium Oxide Cylinder MONK6B Results, for the case of $15 \mathrm{~kg} \mathrm{PuO}$ in a cylinder with height/diameter $=1$, and water reflected, and with $\mathrm{H} / \mathrm{Pu}=2$. The disruptive nature of a seismic event would not assemble an ideal critical configuration, but rather disperse the $\mathrm{Pu}$ metal or $\mathrm{PuO}_{2}$ in a confused configuration.

Water ingress would be considered as another contingency, because even though water pipe failures or sprinkler activation could result from the seismic forces, the probability of such failures and their occurrence over the glovebox would be less than unity and thus have to be compounded with the earthquake probability. Here too the potential for criticality, with a pool slurry forming in the bottom box edge, is low because of the non-optimum geometry attained. 


\subsection{PARAMETRIC STUDY OF PLUTONIUM METAL WITH PLUTONIUM OXIDE}

Parametric studies are unrealistic and do not apply to physical situations, but are meant to represent the very extremes possible with certain quantities of plutonium materials.

The five results of this parametric study are:

- $\quad 2.5 \mathrm{~kg}$ plutonium metal per container is a necessary limit,

- $\quad \mathrm{PuO}_{2}$ mass 7 imits can be much higher than Pu metal mass limits.

- Defined a plutonium metal $/ \mathrm{PuO}_{2}$ mass range where no other administrative controls are necessary.

- Demonstrated the necessity of including tight fitting $\mathrm{H}_{2} \mathrm{O}$ reflection for a conservative computer model, and

- Demonstrated the conservatism inherent in using $\mathrm{H} / \mathrm{Pu}=2$ composition.

The following cases have plutonium metal buttons surrounded by $\mathrm{PuO}_{2}$ with plutonium density at $5.5 \mathrm{~g} / \mathrm{cm}^{3}$ and $\mathrm{H} / \mathrm{Pu}=2,100 \mathrm{wt} \%{ }^{239} \mathrm{Pu}$, in a cylindrical geometry of height to diameter equal to one. The blocked area in Table 9.1, on the side of low Pu metal and low $\mathrm{PuO}_{2}$, shows where no administrative controls, other than mass limits, are necessary for criticality safety. Outside the blocked area, there will be reliance on administrative controls to support criticality safety.

In Table 9.2, the columns across from the left to the right are for zero, one, two, three, and four $2.5 \mathrm{~kg}$ plutonium metal buttons stacked up. The rows down are for increments of $2.5 \mathrm{~kg} \mathrm{PuO}$, at a density of $5.5 \mathrm{~g} \mathrm{Pu} / \mathrm{cm}^{3}$.

\begin{tabular}{|c|c|c|c|c|c|}
\hline \multicolumn{6}{|c|}{$\begin{array}{l}\text { Table } 9.2 \text { Plutonium Metal and Plutonium 0xide MONK6B Results. } \\
\text { Plutonium Metal Density } 19.465 \mathrm{~g} / \mathrm{cm}^{3} \\
\mathrm{PuO}_{2} \text { with Pu } 5.5 \mathrm{~g} / \mathrm{cm}^{3} \text { and Hydrogen/239 } \mathrm{Pu}=2 \\
2.5 \mathrm{Ki} \text { logram Metal Buttons Stacked } \\
\text { Surrounding PuO }{ }_{2} \text { Cyl inder Height = Diameter } \\
\text { Reflection is } 2 \text { Inch Water on Sides and Top } \\
\text { EXTREMELY CONSERVATIVE CALCULATIONS }\end{array}$} \\
\hline & $0.0 \mathrm{~kg} \mathrm{Pu}$ & $2.5 \mathrm{~kg} \mathrm{Pu}$ & $5.0 \mathrm{~kg} \mathrm{Pu}$ & $7.5 \mathrm{~kg} \mathrm{Pu}$ & $10.0 \mathrm{~kg} \mathrm{Pu}$ \\
\hline $0.0 \mathrm{~kg} \mathrm{PuO}$ & $0.0000 \pm 0.0000$ & $0.7067 \pm 0.0028$ & $0.9215 \pm 0.0031$ & $1.0320 \pm 0.0033$ & $1.0970 \pm 0.0035$ \\
\hline $2.5 \mathrm{~kg} \mathrm{PuO}$ & $0.5441 \pm 0.0024$ & $0.8057 \pm 0.0034$ & $0.9944 \pm 0.0035$ & $1.1103 \pm 0.0036$ & $1.1537 \pm 0.0036$ \\
\hline $5.0 \mathrm{~kg} \mathrm{PuO}$ & $0.6916 \pm 0.0029$ & $0.8624 \pm 0.0034$ & $1.0303 \pm 0.0037$ & $1.1392 \pm 0.0039$ & $1.2018 \pm 0.0038$ \\
\hline $7.5 \mathrm{~kg} \mathrm{PuO}$ & $0.7790 \pm 0.0029$ & $0.9134 \pm 0.0033$ & $1.0577 \pm 0.0037$ & $1.1728 \pm 0.0040$ & $1.2297 \pm 0.0039$ \\
\hline $10.0 \mathrm{~kg} \mathrm{PuO}$ & $0.8461 \pm 0.0030$ & $0.9510 \pm 0.0034$ & $1.0816 \pm 0.0040$ & $1.2052 \pm 0.0039$ & \\
\hline $12.5 \mathrm{~kg} \mathrm{PuO}$ & $0.9050 \pm 0.0032$ & $0.9855 \pm 0.0036$ & $1.1041 \pm 0.0037$ & & \\
\hline $15.0 \mathrm{~kg} \mathrm{Pu0_{2 }}$ & $0.9566 \pm 0.0033$ & $1.0179 \pm 0.0036$ & & & \\
\hline $17.5 \mathrm{~kg} \mathrm{PuO}$ & $0.9925 \pm 0.0034$ & $1.0521 \pm 0.0035$ & & & \\
\hline $20.0 \mathrm{~kg} \mathrm{Pu0_{2 }}$ & $1.0290 \pm 0.0035$ & & & & \\
\hline
\end{tabular}


The first column shows that the single contingency of double batching of $\mathrm{PuO}_{2}$ for $10 \mathrm{~kg} \mathrm{Pu}$ in a single cylinder does not compromise criticality safety. The double contingency of triple batching of $\mathrm{PuO}_{2}$ together for $15 \mathrm{~kg}$ plutonium in a single cylinder does exceed the criticality safety limit. The volume required is $15,000 \mathrm{gPu} / 5.5 \mathrm{~g} \mathrm{Pu} / \mathrm{cm}^{3}=2.727 .27 \mathrm{~cm}^{3}=2.73$ Liters, which is larger than any single container except the sieve shaker pan and one sieve screen in a stack.

The second column shows that the single contingency of double batching of one $2.5 \mathrm{~kg}$ plutonium metal button with $5 \mathrm{~kg}$ of $\mathrm{PuO}_{2}$ in a single cylinder does not compromise criticality safety. The double contingency of triple batching of one $2.5 \mathrm{~kg}$ plutonium metal button with $10 \mathrm{~kg}$ of $\mathrm{PuO}_{2}$ together in a single cylinder also does not compromise criticality safety. The volume required is one plutonium metal button and $10 \mathrm{~kg} \mathrm{PuO}_{2}$ is: Liters,

$2.5 \mathrm{~kg} \mathrm{Pu} / 19.465 \mathrm{~g} \mathrm{Pu} / \mathrm{cm}^{3}+10 . \mathrm{kg} \mathrm{Pu} / 5.5 \mathrm{~g} \mathrm{Pu} / \mathrm{cm}^{3}=1,946.62 \mathrm{~cm}^{3}=1.95$

which approaches the size of single containers and the sieve shaker catch pan.

The third column shows that a single contingency of double batching two $2.5 \mathrm{~kg}$ plutonium metal buttons does not compromise criticality safety. An additional contingency of combining $2.5 \mathrm{~kg}$ of $\mathrm{PuO}_{2}$ with double batched $5.0 \mathrm{~kg}$ of plutonium metal does exceed the $k_{\text {eff }}=0.9350$ criticality safety 1imit.

The fourth and fifth columns show that multiple contingencies of stacking multiple $2.5 \mathrm{~kg}$ plutonium metal buttons does exceed the $k_{\text {eff }}=0.9350$ criticality safety limit.

There is conservatism in Table 9.2, Plutonium Meal and Plutonium 0xide MONK6B Results, due to the $\mathrm{H} / \mathrm{Pu}=2$ composition, and the thickness of the water reflector being 2 inches instead of the 1 inch used in Table 9.1, HC-21A Normal and Off-Norma1 MONK6B Results.

The conservatism in Table 9.2 calculations is demonstrated by two additional series of calculations. Table 9.3, Three Button Plutonium Metal Stack MONK5B Results, shows the effect of changing the water reflection and the ${ }^{240} \mathrm{Pu}$ wt $\%$. Table 9.4, $15.0 \mathrm{Kilogram} \mathrm{Plutonium} \mathrm{Oxide} \mathrm{Cylinder} \mathrm{MONK6B}$ Results, shows the effect of changing the $\mathrm{H} / \mathrm{Pu}=2$ and the water reflection.

Table 9.3 shows that the $30 \mathrm{~cm}$ (12 in.) of $\mathrm{H}_{2} \mathrm{O}$ reflection outside the glovebox has only a small effect of the $k_{\text {eff }}$, while the $5.08 \mathrm{~cm}(2 \mathrm{in}$.) of close fitting $\mathrm{H}_{2} \mathrm{O}$ reflection is sufficient to raise the $\mathrm{k}_{\text {eff }}$ from $0.9078 \pm$ 0.0033 (acceptable according to the $k_{\text {eff }}<0.935$ limit) to $k_{\text {eff }}$ of $1.0320 \pm$ 0.0033 (prompt critical!). The ${ }^{240} \mathrm{Pu}$ wt\% did not change the $k_{\text {eff }}$ more than the uncertainty of these Monte Carlo calculations. The point here is that glovebox models must include at least $2.54 \mathrm{~cm}$ (1 in.) of water reflection inside the glovebox as part of the mode $i$ in order to bound the effect of human hands inside plastic gloves picking up parts and containers. 


\begin{tabular}{|c|c|c|}
\hline Table 9.3 & \multicolumn{2}{|c|}{$\begin{array}{l}\text { Three Button Plutonium Metal Stack MONK6B Results. } \\
\text { Plutonium Metal Density } 19.465 \mathrm{~g} \mathrm{Pu/ \textrm {cm } ^ { 3 }} \\
2.5 \mathrm{Ki} \text { logram Metal Buttons Stacked } \\
\text { Variation on Top Line (from Table 9.2) }\end{array}$} \\
\hline \multicolumn{2}{|c|}{$\begin{array}{l}3 \text { Stacked Buttons, } 12 " \mathrm{H}_{2} \mathrm{O} \text { outside } \mathrm{HC}-21 \mathrm{~A} \text {, } \\
2^{2 "} \mathrm{H}_{2} \mathrm{O} \text { around stack, }{ }^{100 \%}{ }^{239} \mathrm{Pu}, 0 \%{ }^{240} \mathrm{Pu}\end{array}$} & $1.0320 \pm 0.0033$ \\
\hline \multicolumn{2}{|c|}{ Top Situation, only without $12^{\prime \prime} \mathrm{H}_{2} \mathrm{O}$ outs ide $\mathrm{HC}-21 \mathrm{~A}$} & $1.0259 \pm 0.0034$ \\
\hline \multicolumn{2}{|c|}{ Top Situation, on 1 y without 2" $\mathrm{H}_{2} \mathrm{O}$ around stack } & $0.9078 \pm 0.0033$ \\
\hline \multicolumn{2}{|c|}{ Top Situation, only with $97 \%{ }^{239} \mathrm{Pu}, 3 \%{ }^{240} \mathrm{Pu}$} & $1.0223 \pm 0.0032$ \\
\hline \multicolumn{2}{|c|}{ Top situation, on $1 y$ with $95 \%{ }^{239} \mathrm{Pu}, 5 \%{ }^{240} \mathrm{Pu}$} & $1.0304 \pm 0.0034$ \\
\hline
\end{tabular}

Table 9.4, 15.0 Kilogram Plutonium Oxide Cylinder MONK6B Results, investigated the effect of $\mathrm{H}_{2} \mathrm{O}$ reflection and the $\mathrm{H} / \mathrm{Pu}=2$ composition effect on $\mathrm{K}_{\text {eff }}$. Reducing the $5.08 \mathrm{~cm}$ ( $2 \mathrm{in}$.) of close fitting $\mathrm{H}_{2} \mathrm{O}$ reflection down to $2.54 \mathrm{~cm}$ ( $1 \mathrm{in}$.) lowered the $k_{\text {eff }}$ from $0.9566 \pm 0.0033$ (not acceptable according to the $k_{\text {eff }}<0.935$ fimit) down to $k_{\text {eff }}$ of $0.8832 \pm 0.0033$ (within the acceptable range!). The composition change from $\mathrm{H} / \mathrm{Pu}=2$ to composition of $\mathrm{H} / \mathrm{Pu}=0 \quad \mathrm{k}_{\text {eff }}$ also dropped the $\mathrm{k}_{\text {eff }}$ down to $0.7716 \pm 0.0029$ (well within the acceptable range). The dominant conservatism is the $\mathrm{H} / \mathrm{Pu}=2$ composition assumption. The $\mathrm{H} / \mathrm{Pu}=2$ is a conservatism for $\mathrm{PuO}_{2}$ that had been heated in the muffle furnaces, but with water entered into the glovebox, it would not be a conservative assumption. The $5.08 \mathrm{~cm}(2 \mathrm{in.})$ of water reflection is more than two gloved hands could cause in neutron reflection around a $7.572 \mathrm{~cm}$ (2.98 in.) radius, $15.143 \mathrm{~cm}(5.96 \mathrm{in}$.) high cylinder. Either conservative assumption relaxed from the Table 9.2 results would show that $15 \mathrm{~kg} \mathrm{Pu}$ in $\mathrm{PuO}_{2}$ has a $k_{\text {eff }}<0.935$, even in one cylinder with $H / D=1$.

\begin{tabular}{|c|c|}
\hline $\begin{array}{c}\text { Table } 9.4 \text { 15.0 Kilogram Plutonium 0xide Cylinder } \\
\text { Plutonium Density } 5.50 \mathrm{~g} \text { Pu/cm } \\
\text { H/D }=1 \text { and Water Reflection Outside } \\
\text { Variation on Top Line (from Table } 9.2\end{array}$ & \\
\hline $\mathrm{PuO}_{2}+\mathrm{H}_{2} \mathrm{O}$ for $\mathrm{H} / \mathrm{Pu}=2, \mathrm{H}_{2} \mathrm{O}$ reflection 2 inches & $0.9566 \pm 0.0033$ \\
\hline $\mathrm{PuO}_{2}$ for $\mathrm{H} / \mathrm{Pu}=0, \mathrm{H}_{2} \mathrm{O}$ reflection 2 inches & $0.7716 \pm 0.0029$ \\
\hline $\mathrm{PuO}_{2}+\mathrm{H}_{2} \mathrm{O}$ for $\mathrm{H} / \mathrm{Pu}=2, \mathrm{H}_{2} \mathrm{O}$ reflection 1 inch & $0.8832 \pm 0.0033$ \\
\hline $\mathrm{PuO}_{2}$ for $\mathrm{H} / \mathrm{Pu}=0, \mathrm{H}_{2} \mathrm{O}$ reflection 1 inch & $0.7014 \pm 0.0026$ \\
\hline
\end{tabular}




\section{WHC-SD-SQA-CSA-520 Rev. 0}

\subsection{REFERENCES}

Altschuler, S. J., June 28, 1994a, CSER 94-007: Criticality Safety Evaluation Report for Muffle Furnace Operations in Glovebox HC-21C. Room 230A. 2345-Z Bui lding, WHC-SD-SQA-CSA-20370, Rev. 0, Westinghouse Hanford Company, Richland, Washington

Altschuler, S. J., June 28, 1994b, CSER 94-008: Criticality Safety Evaluation Report for Transfer Glovebox HC-2 and Glovebox HC-21A. Room 230A, 2345-Z Building to Support Muffle Furnace Operations, WHC-SD-SQA-CSA-20371, Rev. 0, Westinghouse Hanford Company, Richland, Washington

Carter, R. D., G. R. Kiel and K. R. Ridgeway, 1968, Criticality Handbook. Volume 2, ARH-600, June 30, 1968 plus updates, Atlantic Richfield Hanford Company, Richland, Washington.

Chiao, Tang, September 24, 1996. Addendum 2 to CSER 94-007, CSER 94-008: Burning One whole Pu Button in Muffle Furnace in HC-21C Hood, WHC-SDSQA-CSA-515, Rev. 0, Westinghouse Hanford Company, Richland, Washington

Erickson, D. G., November 1996, CSER 96-028, PFP Vault \#2 Storage Racks. WHC-SD-SQA-CSA-524, Rev. 0, Westinghouse Hanford Company, Richland, Washington

Geiger, J. L., December 21, 1995, CSER 95-005 Addendum 1, Stainless Stee Insulation. WHC-SD-SQA-CSA-20404, Rev. 0, Westinghouse Hanford Company, Richland, Washington

Hess. A. L., January 19, 1996a. Addendum 1 to CSER 94-007, CSER 94-008: Use of 2.2 Liter Boats in Muffle Furnace Operations at PFP, WHC-SD-SQA-CSA20408, Rev. 0, Westinghouse Hanford Company, Richland, Washington

Hess. A. L., 1996b. CSER 96-003, Additions of Sphincter Port and Grinder to Glovebox HC-21A, WHC-SD-SQA-CSA-501, Rev. 0, Westinghouse Hanford Company, Richland, Washington

Hess, A. L., 1996c, CSER 96-008. Muffle Furnace Gloveboxes Used for Pu Stabilization at PFP. WHC-SD-SQA-CSA-506, Rev. 0, Westinghouse Hanford Company, Richland, Washington

Macklin, L. L., and E. M. Mi1ler, 1992, CCVR 91-001; MONK6A Pu Va7idation. WHC-SD-SQA-CSWD-20015, Rev. 0, Westinghouse Hanford Company, Richland, Washington

Miller, E. M., 1994, CCVR 94-001; MONK6B Pu Validation. WHC-SD-SQA-CSWD-20019, Rev. 0, Westinghouse Hanford Company, Richland, Washington

Paxton, H.C. and N L. Provost 1986, Critical Dimensions of Systems Containing ${ }^{235} \mathrm{U}$, Pu and ${ }^{233} \mathrm{U}, 1986$ Revision. LA-10860-MS, LOS Alamos National Laboratory, Los Alamos, New Mexico. 


\section{WHC-SD-SQA-CSA-520 Rev. 0}

WHC 1977, March 1977, HC-21A Pu Oxide Blending Facility - General Arrangement and Drawing List, drawing $\mathrm{H}-2-28450$, Rev. 0, Westinghouse Hanford Company, Richland Washington.

WHC 1994a, Apri1 27, 1994, Make-up Hood Arrangement HC-21-A \& HC-21-C. drawing $\mathrm{H}-2-19669$, Rev. 0, Westinghouse Hanford Company, Richland Washington.

WHC 1994b, June 8, 1994, HC-21C \& HC-21A Sludge Stabilization Glovebox Arrangement, drawing H-2-140585, Rev. 0. Westinghouse Hanford Company, Richland Washington.

WHC 1996a, January 1996. Room and Door Numbers (Z-Plant Area Plan), drawing H-2-80249 Sheet 1, Rev. 18, Westinghouse Hanford Company, Richland Washington.

WHC 1996b, August 1996, Room and Door Numbers (First Floor), drawing H-2-80249 Sheet 2, Rev. 20, Westinghouse Hanford Company, Richland Washington.

WHC 1996c. September 13, 1996. Criticality Prevention Specification. Glovebox HC-21A: Muffle Furnace Operations Support, CPS-Z-165-80621, Rev. Mod. D-0. Westinghouse Hanford Company, Richland, Washington.

WHC 1996d. September 13, 1996, Criticality Prevention Specification, Glovebox HC-21C: Muffle Furnace Operations, CPS-Z-165-80622, Rev. Mod. C-0. Westinghouse Hanford Company, Richland, Washington. 
WHC-SD-SQA-CSA-520 Rev. 0

\author{
APPENDIX A \\ INDEPENDENT REVIEW COMMENTS AND CHECKLIST
}

A-1 


\section{WHC-SD-SQA-CSA-520 Rev. 0}

This page intentionally left blank 
WHC-SD-SQA-CSA-520 Rev. 0

TECHNICAL PEER REVIEW

E. M. Miller of the Criticality \& Shielding Group carried out an independent, technical review of this CSER 96-023, for which the following comments were provided.

The first concern of this reviewer is that the high reactivity of the buttons and cans be impressed on fissile material handlers assigned to this glovebox. Two plutonium metal buttons placed flat ends together and cupped in two gloved hands is close to a sphere of $5 \mathrm{~kg}$ of plutonium metal reflected by one inch of water. This assembly needs only a few more inches of reflection to go critical. A fully reflected sphere of $5.45 \mathrm{~kg}$ of plutonium metal is a critical assembly. Fortunately, plutonium buttons are normally less than $2.5 \mathrm{~kg}$ each and the glovebox has an end open to the conveyor to let water flow out before a depth representative of full water reflection could accumulate. Table 9.1 shows that 3 loaded $4.4 \mathrm{~kg}$ Pu cans are safely subcritical even with one inch of water reflection from hands in plastic gloves. However, four of the cans similarly reflected are a critical assembly. The potential for a problem arises because each container has so much fissile material. It is fortunate that one person's hands can not give one inch reflection to four cans. But the change that one can can make needs to be communicated to operators as well as the amount of reflection that a plastic ALARA shield represents. Note well the sensitivity $k_{\text {eff }}$ has to reflector thickness shown in Table 9.4.

The technical arguments for qualifying the criticality safety of the HC-21A glovebox were found to be sound, the computer runs fairly represented, and the quoted criticality parameters in the text and tables were confirmed by review of the referenced data and computer runs. The limits presented in the analysis are not optimum for operations, but are safely subcritical even for water entry into the glovebox. A revision 1 to the CSER may improve the operability of the criticality limits.

The assessment of criticality safety for water entry is based on handbook values to set mass and volume limits for groupings of containers. These values were checked. The limits for dry product were assessed by computer run. These runs were reviewed for atom densities of plutonium and other materials, for the geometry by the input and by the pictorial representation in scan runs, for the volumes of containers computed by the program as a check on the input dimensions, that the energy spectrum of the neutrons was a hard spectrum, that a 11 plutonium masses had fissions, and that each calculation converged. Not all computer runs were checked, but a 11 runs in Table 9.1 were and the runs along the hightighted boundary in Table 9.2 were. 


\section{WHC-SD-SQA-CSA-520 Rev. 0}

A number of conservative representations were found in the input that were not given in the text. Table 9.1 was originally labelled as having a one inch water reflection while the model run had two inches, a conservative representation. A plutonium metal button height of $3.5615 \mathrm{~cm}$ was used rather than the usua $3.244 \mathrm{~cm}$. This translates to a button mass of $2.74 \mathrm{~kg}$ rather than the normal $2.5 \mathrm{~kg}$ upper 1imit. Again this is a conservative representation. For Table 9.1. the glovebox height is 54 inches above the concrete floor. For Table 9.2 runs, the height is 48 inches. This is a conservative representation of the actual 54 inch height. Cases HC21AA7 and HC21AAB both are listed in Table 9.1 as modelling 3 side-by-side boats containing a $2.5 \mathrm{~kg}$ button and $5 \mathrm{~kg}$ of plutonium oxide. The $\mathrm{k}_{\text {eff }} \mathrm{s}$ are 0.80 and 0.89 . The difference is the higher $k_{\text {eff }}$ is due to two inches of water on top and filling the space in the boat water while the other case has only one inch of water reflector. The analyses used an albedo to model thick concrete on the outside surface of a $20 \mathrm{~cm}$ thick concrete slab. This is correct for a thermalized neutron spectrum, but the dry plutonium has a hard spectrum. At least $40 \mathrm{~cm}$ of concrete needs to be modeled before the albedo is used. However, this arrangement returns more neutrons than would the thicker concrete slab model. The only nonconservative modelling found was the use of $19.464 \mathrm{~g} / \mathrm{cc}$ for plutonium metal rather than the theoretical value of $19.81 \mathrm{~g} / \mathrm{cc}$ or $19.6 \mathrm{~g} / \mathrm{cc}$ for measured solid plutonium. This is a smal1 difference from the most conservative values and is more dense than would be expected for actual buttons.

The contingencies used to ensure that it took two contingencies before an operation had a $k_{\text {eff }}$ greater than 1.0 were found to cover al1 reasonable challenges to the operational limits. An added container or an added mass unit to each operation was considered. Adding water to open containers and the glovebox, fire, and earthquake were considered. The groupings of container volume and contained plutonium mass were limited to maintain an adequate margin from criticality allowables. The highest plutonium density, $5.5 \mathrm{~g} / \mathrm{cc}$, in oxide of any allowed operation at PFP, the vertical calciner output density limit, is used in the analysis. This is another conservatism in the anaTysis.

This CSER adequately analyzes the criticality hazards of processing plutonium in glovebox $H C$-21A. Contingencies have been adequately analyzed. Based on the iimits specified in this CSER, the processing of plutonium metal buttons and of plutonium oxide can be carried out within criticality a) lowables. 
WHC-SD-SQA-CSA-520 Rev. 0

\section{CHECKLIST FOR INDEPENDENT REVIEW}

Document Reviewed: CSER 96-023:

Author:

PFP Glovebox HC-21A With 4.4 Kilogram Plutonium Cans Warren D. Wittekind

Yes No $\quad \underline{N} / \mathrm{A}$

[X] [ ] [ ]

$[X] \quad[] \quad[]$

$[X][] \quad[]$

$[X] \quad[] \quad[]$

$[X] \quad\left[\begin{array}{ll}] & {[}\end{array}\right.$

$[X] \quad[] \quad[]$

$[x] \quad[] \quad[]$

$[X] \quad[] \quad[]$

[X] [ ] [ ]

$[X] \quad[\quad] \quad[]$

$[X] \quad[\quad] \quad[\quad]$

$[X] \quad[] \quad[]$

$[X] \quad[\quad] \quad[\quad]$

$[X] \quad[\quad] \quad[]$

$\left[\begin{array}{lll}{[} & {[}\end{array}\right][X]$

$[X] \quad[\quad] \quad[]$

$[X] \quad[\quad] \quad[]$

$[X] \quad[][]$

$[X] \quad[\quad] \quad[]$

$[X] \quad[] \quad[]$

Problem completely defined.

Necessary assumptions explicitly stated and supported.

Computer codes and data files documented.

Data checked for consistency with original source information as applicable.

Mathematical derivations checked including dimensional

consistency of results.

Models appropriate and used within range of validity or use outside range of established validity justified.

Hand calculations checked for errors.

Code run streams correct and consistent with analysis

documentation.

Code output consistent with input and with results reported in analysis documentation.

Acceptability limits on analytical results applicable and supported. Limits checked against sources.

Safety margins consistent with good engineering practices.

Conclusions consistent with analytical results and applicable 7 imits.

Results and conclusions address all points required in the problem statement.

Have all reasonable accidents been considered?

Has low density water (steam) been evaluated as a moderator?

Is the fuel and other hardware composition correct?

Are the cases considered conservative?

Do the computer models adequately reflect the actual

geometry? Have cross sectional cuts of the geometry been made and do they show the desired geometry?

Has the analysis been reviewed by Safety? This may not be required in a preliminary design.

Has the reviewer completed the Criticality Safety Course for Managers and Engineers?

Date completed $\underline{06 / 15 / 95}$

Reviewed by: Edward M. Miller (original sianed) Date 12/3/96

NOTE: Any hand calculations, notes, or summaries generated as part of this review should be signed, dated, and attached to this checkl ist. Materials should be labeled and recorded so that it is intelligible to a technically-qual ified third party. 


\section{WHC-SD-SQA-CSA-520 Rev. 0}

This page intentionally left blank 
WHC-SD-SQA-CSA-520 Rev. 0

APPENDIX B

MONK COMPUTER CODE VALIDATION 
WHC-SD-SQA-CSA-520 Rev. 0

This page intentionally left blank 


\section{B.1 VALIDATION PROCEDURE}

The validation of the methods used in the analysis consists of testing the ability of the code and neutron cross-sections in calculations of known critical configurations, which are various benchmark experiments with the fissile material in question. Such analyses determine a calculational bias (the deviations of calculated $k_{\text {eff }}$ values from unity for the benchmark cases) and the uncertainties culminating from the experimental and calculational errors.

The safety criteria for future calculations on undetermined systems requires that the bias-adjusted $k_{\text {eff }}$ does not exceed 0.95 at the $95 \%$ confidence level. This is expressed by the following formula:

$$
k_{\text {eff }}=k_{\text {calc }}-\text { bias }+\left(U_{b}^{2}+U_{c}^{2}\right)^{1 / 2} \leq 0.95
$$

where $k_{\text {calc }}=k$ value given by calculation for system in question. bias $^{\text {calc }}=$ mean difference $\left(k_{\text {calc }}-1.0\right)$ for benchmark criticals

$U_{b}=95 \%$ confidence level uncertainty in the bias determination, and $U_{c}^{b}=95 \%$ confidence level uncertainty in new calculation.

Thus, the bias-adjusted $k_{\text {eff }}$ includes the statistical uncertainties.

\section{B.2 GENERIC VALIDATION FOR PLUTONIUM SYSTEMS}

A report by L. L. Macklin and E. M. Miller, MONK6A Pu Validation (Mack 1 in and Miller 1992), presents the results of calculations to determine a generic bias for plutonium configurations, as encountered in the Plutonium Finishing Plant. Seventy benchmark experiments were calculated, ranging from simple metal spheres to highly dilute ( $9 \mathrm{~g}$ plutonium per 7iter) plutonium nitrate solution spheres, and also compacts of $\mathrm{PuO}_{2}$ blended with polystyrene. A mean $k_{\text {eff }}$ value of 1.0047 was determined over the full experimental range, with an overall standard deviation of 0.0097 .

The direct calculational bias is thus +0.0047 (average $k_{\text {eff }}$ greater than unity). Accounting for the uncertainties using a tolerance limit analysis, the report then concludes that

At least $95 \%$ of a 11 critical experiments of this type computed by the MONK6A code will produce calculated $k_{\text {eff }}$ values greater than 0.9857 with $95 \%$ confidence.

For a standard deviation $(\sigma)$ of 0.01 or less for the convergence of a future calculation $\left(U_{c}\right)$, the 0.9857 value is lowered to 0.9855 . Rounded conservatively, a value of +0.015 can be used for $\left[-b i a s+\left(U_{b}^{2}+U_{c}^{2}\right)^{1 / 2}\right]$. On this basis, it is determined that the true $k_{\text {eff }}$ of an analyzed configuration with plutonium wi 11 not exceed 0.95 with a $95 \%$ confidence level if the calculated value $\left(k_{\text {calc }}, \sigma \leq 0.01\right)$ is limited to a maximum value of 0.935 . 
The $95 \%$ confidence level on $99.9 \%$ of the data is 0.9699 . So a subcritical margin of $5 \%$ is $3.5 \%$ larger than the uncertainties between the $95.0 \%$ and $99.9 \%$ coverage of the benchmark data.

\section{B.3 VALIDATION OF MONK6B}

The validation of the MONK6B code on the SUN microcomputers was documented in Miller, 1994. The essence of the validation was crosscorrelation of calculational results obtained with this code version and computer with results for identical input models done on the CRAY machine with MONK6A, as reported in the previous subsection. Also, the equivalence of MONK6B to MONK6A was well documented by the code vendors, the United Kingdom Atomic Energy Authority, in the verification package supplied with the software. follows:

The abstract from CCVR 94-001 summarizes the validation study as

The MONK6B validation for bare plutonium and plutonium water systems on the SUN computer and operating system is established in this report. Because the calculational method and nuclear crosssections have not changed from the MONK6A code to the MONK6B code, the bias determination done for MONK6A is valid for MONK6B. 
WHC-SD-SQA-CSA-520 Rev. 0

\section{APPENDIX C \\ REPRESENTATIVE MONK6B INPUT FILES}

CASE Description

HC21AA9. INP, Glovebox, 3 Furnace Boats, $4-4.4 \mathrm{~kg}$ Pu cans, nominal reflection HC21AB6. INP, Glovebox. Sieve Pan, $3-4.4 \mathrm{~kg}$ Pu cans, 1/8" Pu0 ${ }_{2}$, nominal refl. HC21AC6. INP, Glovebox, $3-4.4 \mathrm{~kg}$ Pu cans, $1 / 8$ " $\mathrm{PuO}_{2}$ layer, nominal reflection B3P000N. INP, $7.5 \mathrm{~kg}$ Pu metal, $0.0 \mathrm{~kg} \mathrm{Pu}$ in $\mathrm{PuO}_{2}$, nominal reflection 
WHC-SD-SQA-CSA-520 Rev. 0

This page intentionally left blank 


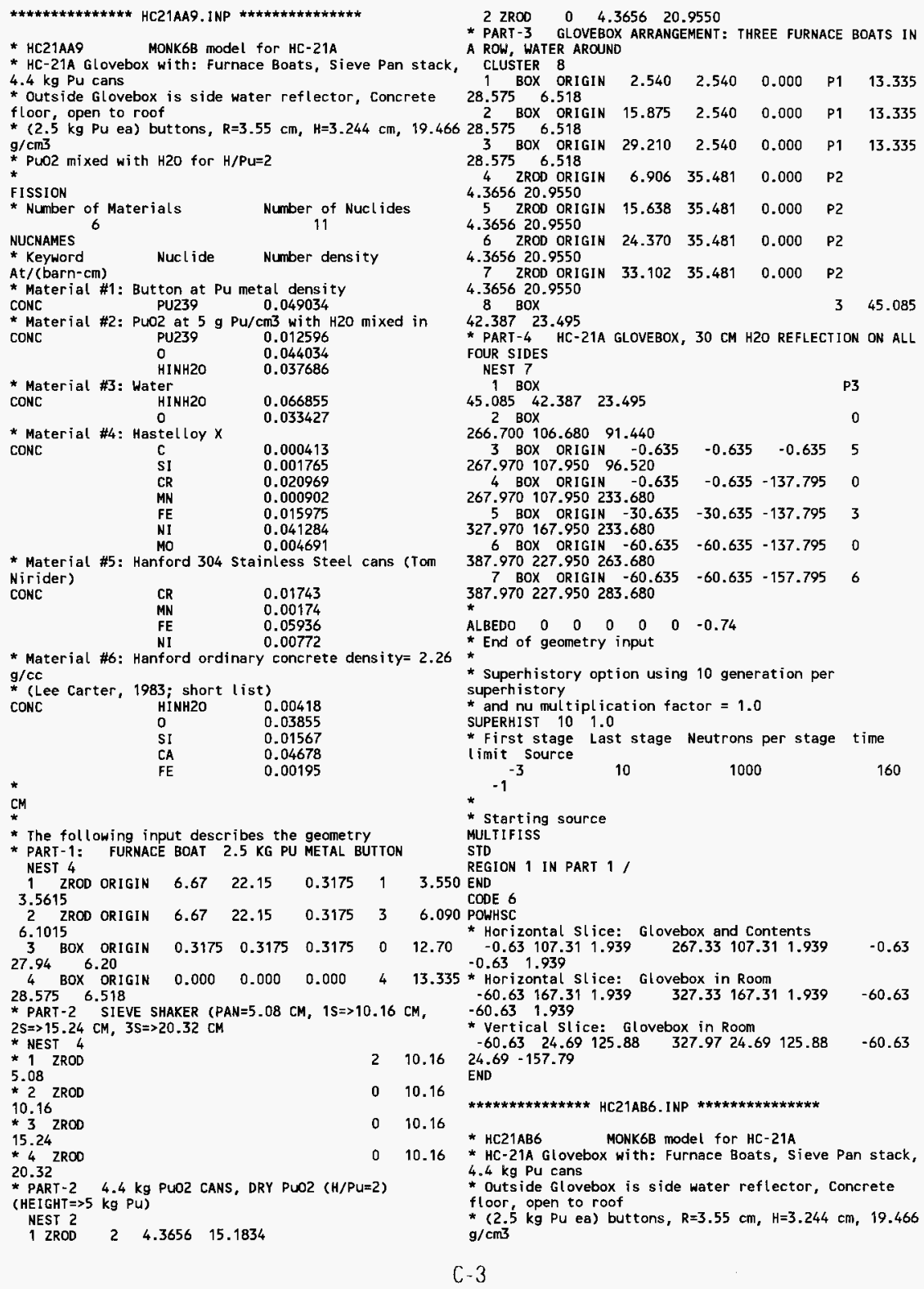




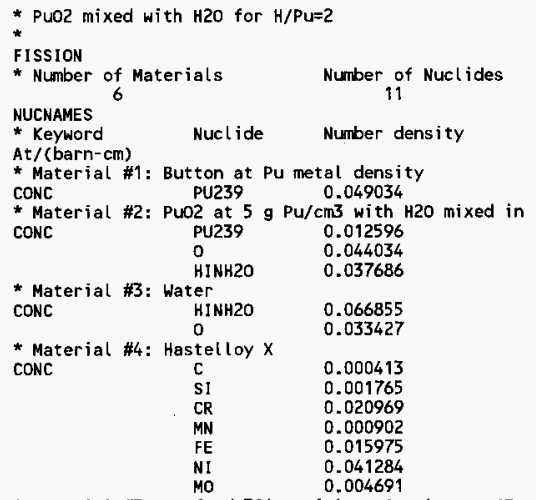

* Material \#5: Hanford 304 stainless Steel cans (Tom Nirider)

$\begin{array}{lll}\text { CONC } & \text { CR } & 0.01743 \\ & \text { MN } & 0.00174 \\ & \text { FE } & 0.05936 \\ \text { HI } & 0.00772\end{array}$

* Material \#6: Hanford ordinary concrete density= 2.26 $\mathrm{g} / \mathrm{cc}$

* (Lee Carter, 1983; short list)

$\begin{array}{lll}\text { CONC } & \text { HINH2O } & 0.00418 \\ & 0 & 0.03855 \\ & \text { SI } & 0.01567 \\ & \text { CA } & 0.04678 \\ & \text { FE } & 0.00195\end{array}$

*

CM

* The following input describes the geometry

* part-1: fuRnace boAT 2.5 KG PU metal bUtTON

* NEST 4

$* 1$ zRoD 3.5615

$\begin{array}{llllll}* 2 & \text { ZRCD ORIGIN } & 6.67 & 14.29 & 0.3175 & 3\end{array}$

6.1015

* 3 BOX ORIGIN

$27.94 \quad 6.20$

* 4 BOX ORIGIN $0.000 \quad 0.000 \quad 0.000$

$28.575 \quad 6.518$

* PART-1 SIEVE SHAKER (PAN=5.08 CM, $1 \mathrm{~S}=>10.16 \mathrm{cM}$,

$2 \mathrm{~S} \Rightarrow 15.24 \mathrm{CM}, 3 \mathrm{~S}=>20.32 \mathrm{CM}$

NEST 2

1 ZROD

5.08

$2 \mathrm{ZROD}$

10.16

* PART-2 $4.4 \mathrm{~kg}$ PuO2 CANS, DRY PUO2 (h/Pu=2)

(HEIGHT $=5 \mathrm{~kg}$ PU)

NEST 2

$\begin{array}{llll}1 \text { ZROD } & 2 & 4.3656 & 15.1834\end{array}$

$\begin{array}{llll}2 \text { ZROD } & 0 & 4.3656 & 20.9550\end{array}$

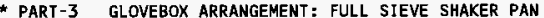
AND 0 SIEVES, H2O AROUND CLUSTER 5 1 ZROD

10.16

${ }_{2}^{10.16}$ ZROD ORIGIN

$\begin{array}{llllll}4.3656 & 20.955 \\ 3 & \text { ZROD ORIGIN } & 14.329 & 2.902 & 0.000 & \text { P2 }\end{array}$

4.365620 .955

$\begin{array}{llllll}4 & \text { ZROD ORIGIN } 10.081 & 10.589 & 0.000 & \text { P2 }\end{array}$

4.365620 .955

5 ZROD

23.495

* part-3 hC-21a glovebox, 30 CM h20 reflection on all FOUR SIDES, 1/8" PUOZ

NEST 8

$\begin{array}{llllll}1 \text { ZROD ORIGIN } & 21.53 & 21.53 & 0.318 & \text { P3 }\end{array}$

$21.526 \quad 23.495$

2 BOX ORIGIN $0.000 \quad 0.000 \quad 0.318 \quad 0$

$266.700106 .680 \quad 91.122$

3 BOX

$266.700 \quad 106.680 \quad 91.440$

4 BOX ORIGIN $-0.635 \quad-0.635 \quad-0.635 \quad 5$

$267.970 \quad 107.950 \quad 96.520$

5 BOX ORIGIN $-0.635 \quad-0.635-137.795$

$267.970 \quad 107.950233 .680$

6 BOX ORIGIN $-30.635 \quad-30.635-137.795 \quad 3$

$327.970 \quad 167.950 \quad 233.680$

7 BOX ORIGIN $-60.635 \quad-60.635-137.795 \quad 0$

$387.970 \quad 227.950 \quad 263.680$

8 BOX ORIGIN $\quad-60.635 \quad-60.635-157.795 \quad 6$

387.970227 .950283 .680

$\begin{array}{lllllll}\text { ALBEDO } & 0 & 0 & 0 & 0 & 0 & -0.74\end{array}$

* End of geometry input

* Superhistory option using 10 generation per

superhistory

* and nu multipl ication factor $=1.0$

SUPERHIST $10 \quad 1.0$

* First stage Last stage Neutrons per stage time

limit source

$$
\begin{array}{llll}
-3 & 10 & 1000 & 160
\end{array}
$$

.

* Starting source

MULTIFISS

STD

REGION 1 IN PART $1 /$

END

CODE 6

POWHSC

* Horizontal slice: Glovebox and Contents

$\begin{array}{llllll}-0.63107 .31 & 1.939 & 267.33 & 107.31 & 1.939 & -0.63\end{array}$

$-0.631 .939$

* Horizontal slice: Glovebox in Room

$\begin{array}{llllll}-60.63167 .31 & 1.939 & 327.33 & 167.31 & 1.939 & -60.63\end{array}$

$3.550-60.63 \quad 1.939$

* Vertical slice: Glovebox in Room

$\begin{array}{llllllll}6.090 & -60.63 & 21.53 & 125.88 & 327.97 & 21.53 & 125.88 & -60.63\end{array}$

$21.53-157.79$

END

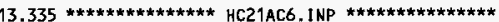

* HC21AC6 MONK6B model for HC-21A

* HC-21A GLovebox with: Furnace Boats, Sieve Pan stack, $4.4 \mathrm{~kg}$ Pu cans

* Outside Glovebox is side water reflector, Concrete

$0 \quad 10.16 *(2.5 \mathrm{~kg}$ Pu ea) buttons, R=3.55 cm, H=3.244 cm, 19.466 $\mathrm{g} / \mathrm{cm} 3$

* PuOz mixed with H2O for $\mathrm{H} / \mathrm{Pu}=2$

FISSION

* Number of Materials Number of Nuclides 6

11

* Keyword Nuclide Number density

At / (barn-cm)

P1

10.16

* Material

CONC

ton at $P u$ metal density

* Material \#2: PuO2 at $5 \mathrm{~g} \mathrm{Pu/cm} 3$ with H2O mixed in

CONC PU239 $\quad 0.012596$

$0 \quad 0.044034$

* Material \#3: Water

$\begin{array}{ll}0 & 0.044034 \\ \text { HINH2O } & 0.037686\end{array}$

CONC HINH2O 0.066855

321.526 
* Material \#4: Hastelloy $X$

$\begin{array}{ccc}\text { CONC } & \text { C } & 0.000413 \\ \text { SI } & 0.001765 \\ \text { CR } & 0.020969 \\ & \text { MN } & 0.000902 \\ \text { FE } & 0.015975 \\ & \text { NI } & 0.041284 \\ \text { MO } & 0.004691\end{array}$

* Material \#5: Hanford 304 Stainless Steel cans (Tom Nirider)

$\begin{array}{lll}\text { CONC } & \text { CR } & 0.01743 \\ & \text { MN } & 0.00174 \\ & \text { FE } & 0.05936 \\ \text { NI } & 0.00772\end{array}$

$327.970 \quad 167.950 \quad 233.680$

$\begin{array}{lllll}7 \text { BOX ORIGIN } & -60.635 & -60.635 & -137.795\end{array}$

387.970227 .950263 .680

8 BOX ORIGIN $-60.635 \quad-60.635-157.795 \quad 6$ 387.970227 .950283 .680

*

$\begin{array}{lllllll}\text { ALBEDO } & 0 & 0 & 0 & 0 & 0 & -0.74\end{array}$

* End of geometry input

* Superhistory option using 10 generation per superhistory

* and nu multiplication factor $=1.0$

SUPERHIST $10 \quad 1.0$

* First stage Last stage Neutrons per stage time

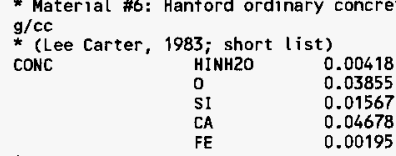

*

CM

* The following input describes the geometry

* parT-1: fURNACE boat 2.5 KG PU metal bUtTon

* NEST 4

* 1 ZROD ORIGIN

3.5615
$* 2$ ZROD ORIGIN

6.1015

$\begin{array}{llllll}6.1015 & & & & & \\ 3 & \text { BOX ORIGIN } & 0.3175 & 0.3175 & 0.3175 & 0\end{array}$

$27.94 \quad 6.20$

* 4 BOX ORIGIN

$6.67 \quad 14.29$

0.317

0.31753

6.6714 .29

0.000

0.000

0.000

4

$3.550 * 0.63 \quad 1.939$

$-3$

$-1$

10

1000

160

* Starting source

MULTIFISS

STD

REGION 1 IN PART $1 /$

END

CODE 6

POWHSC

* Horizontal slice: Glovebox and contents

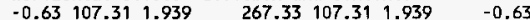

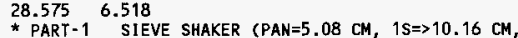
$2 \mathrm{~S}=>15.24 \mathrm{CM}, 3 \mathrm{~S}=>20.32 \mathrm{cM}$

* NEST 4

* 1 ZROD

5.08

* 2 ZROD

10.16

* 3 ZROO

15.24

* 4 ZROD

20.32

- PART-1 $4.4 \mathrm{~kg}$ PuO2 CANS, DRY PuO2 (h/Pu=2)

(HEIGHT $\Rightarrow 5 \mathrm{~kg} \mathrm{PU}$ )

NEST 2

1 ZROD

$\begin{array}{lll}2 & 4.3656 & 15.1834\end{array}$

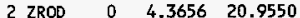

* Part-2 glovebox arRangement: 3 full 4.4 KG

PLUTONIUM CANS, HZO AROUND

CLUSTER 4

\begin{tabular}{|c|c|c|c|c|}
\hline \multirow{4}{*}{$\begin{array}{l}1 \text { ZROD ORIGIN } \\
4.3656 \text { 20.955 } \\
2 \text { ZROD ORIGIN } \\
4.365620 .955 \\
3 \text { ZROD ORIGIN } \\
4.365620 .955 \\
4 \text { 2ROD ORIGIN } \\
10.68723 .495\end{array}$} & \multicolumn{2}{|l|}{0.0} & 0.0 & 0.0 \\
\hline & \multicolumn{2}{|c|}{-4.3660} & 7.5621 & 0.0 \\
\hline & \multicolumn{2}{|c|}{4.3660} & 7.5621 & 0.0 \\
\hline & 0.0 & & 3.781 & 0.0 \\
\hline $\begin{array}{l}\text { PART }-3 \\
\text { UR SIDES }+1 / 8=\end{array}$ & $\begin{array}{l}\text { GLOVEBOX, } \\
\text { I PUO2 }\end{array}$ & $30 \mathrm{~cm}$ & HZO REFLEC & \\
\hline $\begin{array}{l}1 \text { ZROD ORIGIN } \\
.687 \quad 23.495\end{array}$ & 10.690 & 10.690 & 0.318 & P2 \\
\hline $\begin{array}{l}2 \text { BOX ORIGIN } \\
6.700106 .680 \\
3 \text { BOX }\end{array}$ & $\begin{array}{r}0.0 \\
91.122\end{array}$ & 0.0 & 8 & 0 \\
\hline $\begin{array}{l}6.700106 .680 \\
4 \text { BOX ORIGIN } \\
7.970 \quad 107.950\end{array}$ & $\begin{array}{l}91.440 \\
-0.635 \\
96.520\end{array}$ & -0.635 & -0.635 & 3 \\
\hline $\begin{array}{l}\text { BOX ORIGIN } \\
970107.9502 \\
\text { BOX ORIGIN }\end{array}$ & $\begin{array}{r}233.6 \\
-30\end{array}$ & 30.635 & $5-137.795$ & \\
\hline
\end{tabular}

$6.090-60.63 \quad 1.939$

* Vertical slice: Glovebox in Room

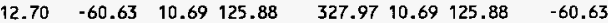
$10.69-157.79$

END

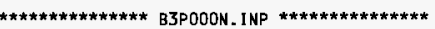

* B3P0OON MONK6B model for HC-21A

$210.16 * 3$ (2.5 kg Pu ea) buttons, $R=3.55 \mathrm{~cm}, H=3.244 \mathrm{~cm}$,

$19.466 \mathrm{~g} / \mathrm{cm}^{3}$

$310.16 * 00.0 \mathrm{~kg} \mathrm{PuO2}$, PuO2 mixed with $\mathrm{H} 2 \mathrm{O}$, shaped to $\mathrm{H} / \mathrm{D}=$ 1

$0 \quad 10.16$ * Reflected by $\mathbf{5 . 0 8} \mathrm{cm}$ of $\mathrm{H} 20$ on radius and top

* sitting on Carbon steel in air over concrete

*

FISSION

- Number of Materials Number of Nuclides 6 10

NUCNAMES

* Keyword Nuclide Number density

At/(barn-cm)

* Mat \#1 - Button at Pu metal density

CONC PU239 0.049034

* Mat \#2 - PuO2 + $\mathrm{H2O}, 5.5 \mathrm{~g} \mathrm{Pu} / \mathrm{cm}^{3}(\mathrm{H} / \mathrm{Pu}=2)$

CONC

PU239 0.013855

O 0.041565

* Mat $\# 3$ - Water

CONC HINH2O 0.066855

$\begin{array}{ll}\text { HINH2O } & 0.066855 \\ 0 & 0.033427\end{array}$

* Mat \#4 - Carbon Steel (1\% Carbon), $7.86 \mathrm{~g} / \mathrm{cm} 3$

CONC $\quad \mathrm{FE} \quad 0.083491$

* Mat \#5 - Concrete per Bob Richard

*ONC \#5 - Concrete per Bob Richard 0.041519

HINH2O $\quad 0.014868$

CA $\quad 0.011588$

SI $\quad 0.00603$ ?

C $\quad 0.003814$

$\begin{array}{ll}\text { C } & 0.003814 \\ \text { AL27 } & 0.000735\end{array}$

MG $\quad 0.000587$

NA23 $\quad 0.000304$

* Mat \#6 - Concrete per ARH-600, 0.0001968 page II F.1-2

CONC

SI 0.04608 
WHC-SD-SQA-CSA-520 Rev. 0

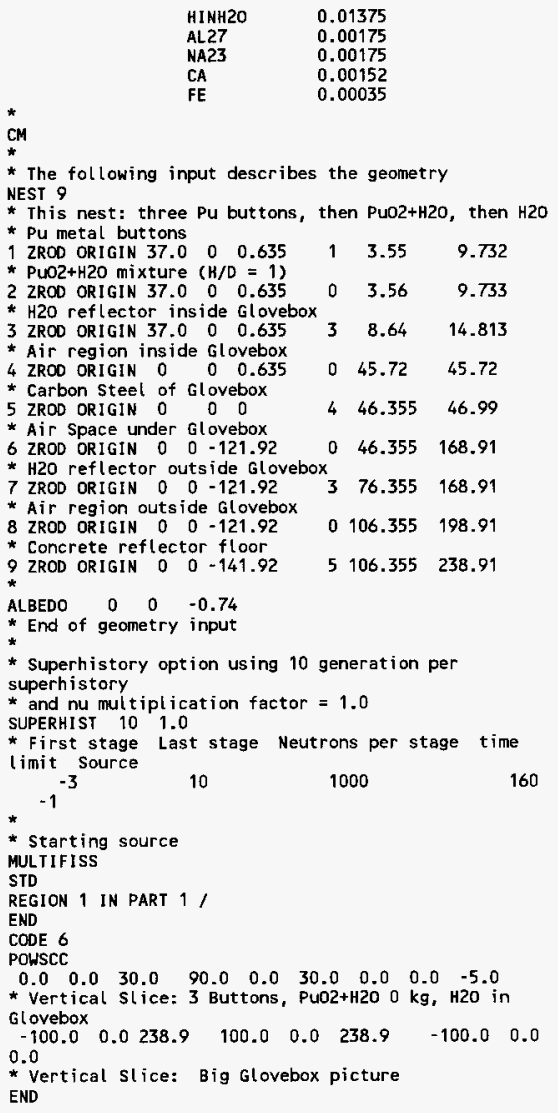


WHC-SD-SQA-CSA-520 Rev. 0

\section{APPENDIX D \\ PARAMETRIC STUDY SPREADSHEET FILES}

Table D.1 O Plutonium Buttons $\mathrm{PuO}_{2}$ Radius and $\mathrm{PuO}_{2}$ Height Calculation Table D.2 1 Plutonium Buttons $\mathrm{PuO}_{2}$ Radius and $\mathrm{PuO}_{2}$ Height Calculation Table D.3 2 Plutonium Buttons $\mathrm{PuO}_{2}$ Radius and $\mathrm{PuO}_{2}$ Height Calculation Table D. 43 Plutonium Buttons $\mathrm{PuO}_{2}$ Radius and $\mathrm{PuO}_{2}$ Height Calculation Table D.5 4 Plutonium Buttons $\mathrm{PuO}_{2}$ Radius and $\mathrm{PuO}_{2}$ Height Calculation 
WHC-SD-SQA-CSA-520 Rev. 0

This page intentionally left blank 
The parametric study of plutonium metal buttons stacked, surrounded by $\mathrm{PuO}_{2}$ with an $\mathrm{H} / \mathrm{D}=1$ geometry, and $5.08 \mathrm{~cm}$ (2 in.) $\mathrm{H}_{2} \mathrm{O}$ on the radius and height had dimensions calculated by spreadsheets. The Pu button is assumed to have $3.255 \mathrm{~cm}$ radius and $3.244 \mathrm{~cm}$ height, and a 2,500.0 g Pu mass. The results of the spreadsheet calculations are tabulated in the following tables. The columns in the followig tables need some description:

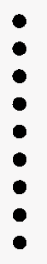
Column 1
Column 2
Column 3
Columin 4
Column 5
Column 6
Column 7
Column 8
Column 9

$\mathrm{PuO}_{2}$ mass in $\mathrm{kg}$

$\mathrm{PuO}_{2}$ volume in $\mathrm{cm}^{3}$

$\mathrm{Pu}$ volume $+\mathrm{PuO}_{2}$ volume in $\mathrm{cm}^{3}$

Calculated $D$ from $\pi / 4 * D^{2} * H=\left(P u O_{2}+P u\right)$ Volume (for $\left.D=H\right)$

Calculated volume from $\pi / 4^{\star} D^{2} \times \mathrm{H}$ ( for $\mathrm{D}=\mathrm{H}$ )

Radius $=D$ in Column $4 / 2.0$

Height $=\mathrm{D}$ in Column 4

Radius of $\mathrm{Pu}+\mathrm{PuO}_{2}$ when height $<\mathrm{Pu}$ button stack height

Height of $\mathrm{Pu}+\mathrm{PuO}_{2}^{2}$ when height $<\mathrm{Pu}$ button stack height

These were the $\mathrm{Pu}$ and $\mathrm{PuO}_{2}$ dimensions used in the MONK6B calculations.

\begin{tabular}{|c|c|c|c|c|c|c|}
\hline \multicolumn{5}{|c|}{ Table D.1 O Plutonium Button Calculation for } & \multirow[t]{2}{*}{0} & \multirow[t]{2}{*}{ Buttons } \\
\hline Pu metal & 0.00 & $\mathrm{Pu}(\mathrm{PuO2})=$ & 5.50 & $\mathrm{~g} / \mathrm{cm} 3$ & & \\
\hline $\mathrm{PuO}_{2} \mathrm{~kg}$ & $\mathrm{PuO}_{2} \mathrm{~cm}^{3}$ & $\mathrm{Pu} \mathrm{cm}^{3}$ & $D=H$ & Cal' $\mathrm{d} \mathrm{cm}^{3}$ & radius & height \\
\hline 0.0 & 0.00 & 0.00 & ERR & ERR & ERR & ERR \\
\hline 2.5 & 454.55 & 454.55 & 8.334 & 454.55 & 4.167 & 8.334 \\
\hline 5.0 & 909.09 & 909.09 & 10.500 & 909.09 & 5.250 & 10.500 \\
\hline 7.5 & 1363.64 & 1363.64 & 12.019 & 1363.64 & 6.010 & 12.019 \\
\hline 10.0 & 1818.18 & 1818.18 & 13.229 & 1818.18 & 6.614 & 13.229 \\
\hline 12.5 & 2272.73 & 2272.73 & 14.250 & 2272.73 & 7.125 & 14.250 \\
\hline 15.0 & 2727.27 & 2727.27 & 15.143 & 2727.27 & 7.572 & 15.143 \\
\hline 17.5 & 3181.82 & 3181.82 & 15.941 & 3181.82 & 7.971 & 15.941 \\
\hline 20.0 & 3636.36 & 3636.36 & 16.667 & 3636.36 & 8.334 & 16.667 \\
\hline
\end{tabular}


WHC-SD-SQA-CSA-520 Rev. 0

\begin{tabular}{|c|c|c|c|c|c|c|c|c|}
\hline \multicolumn{5}{|c|}{$\begin{array}{l}\text { Dimension calculations for } \mathrm{Pu} 02 \\
\text { in an } \mathrm{H} / \mathrm{D}=1 \text { geometry }\end{array}$} & 1 & Button & & \\
\hline $\begin{array}{l}\mathrm{Pu} \\
\text { metal }\end{array}$ & 128.44 & $\mathrm{Pu}(\mathrm{Pu} 02)=$ & 5.50 & $\mathrm{~g} / \mathrm{cm}^{3}$ & & & & \\
\hline $\begin{array}{r}\mathrm{PuO}_{2} \\
\mathrm{~kg}\end{array}$ & $\begin{array}{c}\mathrm{PuO}_{3} \\
\mathrm{~cm}^{3}\end{array}$ & $\mathrm{Pu} \mathrm{cm}^{3}$ & $D=H$ & $\begin{array}{r}\mathrm{Cal} \mathrm{Cm}^{\mathrm{d}} \\
\mathrm{Cm}^{3}\end{array}$ & radius & height & radius & height \\
\hline 0.0 & 0.00 & 128.44 & 5.468 & 128.44 & 2.734 & 5.468 & 3.2550 & 3.2440 \\
\hline 2.5 & 454.55 & 582.98 & 9.054 & 582.98 & 4.527 & 9.054 & 0.0000 & 0.0000 \\
\hline 5.0 & 909.09 & 1037.53 & 10.972 & 1037.53 & 5.486 & 10.972 & 0.0000 & 0.0000 \\
\hline 7.5 & 1363.64 & 1492.07 & 12.385 & 1492.07 & 6.193 & 12.385 & 0.0000 & 0.0000 \\
\hline 10.0 & 1818.18 & 1946.62 & 13.533 & 1946.62 & 6.767 & 13.533 & & \\
\hline 12.5 & 2272.73 & 2401.16 & 14.514 & 2401.16 & 7.257 & 14.514 & & \\
\hline 15.0 & 2727.27 & 2855.71 & 15.377 & 2855.71 & 7.689 & 15.377 & & \\
\hline 17.5 & 3181.82 & 3310.25 & 16.153 & 3310.25 & 8.077 & 16.153 & & \\
\hline
\end{tabular}

Table D.3 2 Plutonium Button Calculation for Radius. Height

\begin{tabular}{|c|c|c|c|c|c|c|c|c|}
\hline \multicolumn{5}{|c|}{$\begin{array}{l}\text { Dimension calculations for } \mathrm{Pu} 02 \\
\text { in an } \mathrm{H} / \mathrm{D}=1 \text { geometry }\end{array}$} & 2 & Button & & \\
\hline $\begin{array}{l}\mathrm{Pu} \\
\text { meta } 1\end{array}$ & 256.87 & $\mathrm{Pu}(\mathrm{PuO2})=$ & 5.50 & $\mathrm{~g} / \mathrm{cm}^{3}$ & & & & \\
\hline $\begin{array}{r}\mathrm{PuO}_{2} \\
\mathrm{~kg} \\
\end{array}$ & $\mathrm{Pu}_{3}$ & $\mathrm{Pu} \mathrm{cm}^{3}$ & $D=H$ & $\begin{array}{r}\mathrm{Ca}]^{\prime} \mathrm{d} \\
\mathrm{cm}^{3} \\
\end{array}$ & radius & height & radius & height \\
\hline 0.0 & 0.00 & 256.87 & 6.890 & 256.87 & 3.445 & 6.890 & 3.2550 & 6.4880 \\
\hline 2.5 & 454.55 & 711.42 & 9.676 & 711.42 & 4.838 & 9.676 & 0.0000 & 0.0000 \\
\hline 5.0 & 909.09 & 1165.96 & 11.408 & 1165.96 & 5.704 & 11.408 & 0.0000 & 0.0000 \\
\hline 7.5 & 1363.64 & 1620.51 & 12.731 & 1620.51 & 6.365 & 12.731 & 0.0000 & 0.0000 \\
\hline 10.0 & 1818.18 & 2075.05 & 13.824 & 2075.05 & 6.912 & 13.824 & & \\
\hline 12.5 & 2272.73 & 2529.60 & 14.768 & 2529.60 & 7.384 & 14.768 & & \\
\hline
\end{tabular}


WHC-SD-SQA-CSA-520 Rev. 0

\begin{tabular}{|c|c|c|c|c|c|c|c|c|}
\hline \multicolumn{5}{|c|}{$\begin{array}{l}\text { Dimension calculations for } \mathrm{PuO2} \\
\text { in an } \mathrm{H} / \mathrm{D}=1 \text { geometry }\end{array}$} & 3 & Button & & \\
\hline $\begin{array}{l}\text { Pu } \\
\text { metal }\end{array}$ & 385.31 & $\mathrm{Pu}(\mathrm{Pu02})=$ & 5.50 & $\mathrm{~g} / \mathrm{cm}^{3}$ & & & & \\
\hline $\begin{array}{r}\mathrm{PuO}_{2} \\
\mathrm{~kg} \\
\end{array}$ & $\begin{array}{r}\mathrm{PuO}_{3} \\
\mathrm{Cm}^{3}\end{array}$ & $\mathrm{Pu} \mathrm{cm}^{3}$ & $D=H$ & $\begin{array}{r}\mathrm{Cal} \mathrm{I}^{\prime} \mathrm{g} \\
\mathrm{cm}^{3}\end{array}$ & radius & height & radius & height \\
\hline 0.0 & 0.00 & 385.31 & 7.887 & 385.31 & 3.943 & 7.887 & 3.2550 & 9.7320 \\
\hline 2.5 & 454.55 & 839.85 & 10.226 & 839.85 & 5.113 & 10.226 & 0.0000 & 0.0000 \\
\hline 5.0 & 909.09 & 1294.40 & 11.812 & 1294.40 & 5.906 & 11.812 & 0.0000 & 0.0000 \\
\hline 7.5 & 1363.64 & 1748.94 & 13.059 & 1748.94 & 6.529 & 13.059 & 0.0000 & 0.0000 \\
\hline 10.0 & 1818.18 & 2203.49 & 14.104 & 2203.49 & 7.052 & 14.104 & & \\
\hline
\end{tabular}

\begin{tabular}{|r|r|r|r|r|r|r|r|r||}
\hline \multicolumn{6}{||c|}{ Table D.5 4 Plutonium Button Calculation for Radius, Height } \\
\hline \hline $\begin{array}{r}\text { Dimension calculations for Pu02 } \\
\text { in an } \mathrm{H} / \mathrm{D}=1 \text { geometry }\end{array}$ & 4 & Button & & \\
\hline $\begin{array}{r}\mathrm{Pu} \\
\text { metal }\end{array}$ & 513.74 & $\mathrm{Pu}(\mathrm{PuO2})=$ & 5.50 & $\mathrm{~g} / \mathrm{cm} 3$ & & & & \\
\hline $\begin{array}{r}\mathrm{PuO}_{2} \\
\mathrm{~kg}\end{array}$ & $\begin{array}{r}\mathrm{PuO}_{3} \\
\mathrm{~cm}^{3}\end{array}$ & $\mathrm{Pu} \mathrm{\textrm {cm } ^ { 3 }}$ & $\mathrm{D}=\mathrm{H}$ & $\begin{array}{r}\mathrm{Ca} \mathrm{Cm}^{\mathrm{d}} \\
\mathrm{Cm}^{3}\end{array}$ & radius & height & radius & height \\
\hline 0.0 & 0.00 & 513.74 & 8.681 & 513.74 & 4.340 & 8.681 & 3.2550 & 12.976 \\
\hline 2.5 & 454.55 & 968.29 & 10.723 & 968.29 & 5.361 & 10.723 & 4.8737 & 12.976 \\
\hline 5.0 & 909.09 & 1422.84 & 12.191 & 1422.84 & 6.095 & 12.191 & 5.9079 & 12.976 \\
\hline 7.5 & 1363.64 & 1877.38 & 13.371 & 1877.38 & 6.685 & 13.371 & 0.0000 & 0.000 \\
\hline \hline
\end{tabular}


WHC-SD-SQA-CSA-520 Rev. 0

This page intentionally left blank 
WHC-SD-SQA-CSA-520 Rev. 0

\section{APPENDIX E \\ MONK6B CASE DESIGNATION AND SUMMARY}

Table E.1 HC-21A Furnace Boat MONK6B Results.

Table E.2 HC-21A Sieve Screen Pan MONK6B Results.

Table E. 3 HC-21A 4.4 kg Pu Cans MoNk6B Results.

Table E.4 Parametric Study of $\mathrm{Pu}$ and $\mathrm{PuO}_{2}$ MONK6B Results. 
WHC-SD-SQA-CSA-520 Rev. 0

This page intentiona11y left blank 
Case designations for the MONK6B calculations can be ascertained from the following tables

\begin{tabular}{|c|c|c|c|c|c|}
\hline \multicolumn{6}{|c|}{$\begin{array}{c}\text { Table E.1 HC-21A Furnace Boat MONK6B Results. } \\
\text { PuO }_{2} \text { with } \mathrm{Pu} 5.5 \mathrm{~g} / \mathrm{cm}^{3} \text { and Hydrogen/239 } \mathrm{Pu}=2 \\
2.5 \mathrm{Ki} \text { logram Metal Buttons } \\
\text { Nominal Reflection is } 1 \text { Inch Water on Sides and Top }\end{array}$} \\
\hline Case \# & $\begin{array}{l}\text { Pu Metal } \\
\text { in Boats }\end{array}$ & \begin{tabular}{|l} 
Sieve \\
Stack
\end{tabular} & $\begin{array}{l}\mathrm{PuO}_{2} \text { in } \\
\text { Cans }\end{array}$ & $\begin{array}{l}\mathrm{PuO}_{2} \text { on } \\
\mathrm{GB} \text { floor }\end{array}$ & $\frac{\text { RESULTS }}{k_{\text {eff }} \pm \sigma}$ \\
\hline HC21AA1 & $302.5 \mathrm{~kg}$ & & & & $0.7633 \pm 0.0029$ \\
\hline HC21AA2 & $602.5 \mathrm{~kg}$ & & & & $0.7646 \pm 0.0029$ \\
\hline HC21AA3 & $302.5 \mathrm{~kg}$ & & & $0.125^{\prime \prime}$ & $0.7736 \pm 0.0037$ \\
\hline HC21AA4 & $602.5 \mathrm{~kg}$ & & & $0.125^{\prime \prime}$ & $0.7875 \pm 0.0034$ \\
\hline HC21AA5 & $402.5 \mathrm{~kg}$ & & & & $0.7718 \pm 0.0028$ \\
\hline HC21AA6 & $365.0 \mathrm{~kg}$ & & & & $0.9268 \pm 0.0033$ \\
\hline HC21AA7 & $\begin{array}{l}302.5 \mathrm{~kg}, \\
5 \mathrm{~kg} \mathrm{PuO}\end{array}$ & & & & $0.8022 \pm 0.0036$ \\
\hline HC21AA8 & $302.5 \mathrm{~kg}$ & $1.65 \mathrm{~L}$ & & & $0.7808 \pm 0.0033$ \\
\hline HC21AA9 & $302.5 \mathrm{~kg}$ & & $4 @ 5 \mathrm{~kg}$ & & $0.9255 \pm 0.0033$ \\
\hline HC21AAA & $6 @ 2.5 \mathrm{~kg}$ & & & & $0.8844 \pm 0.0030$ \\
\hline HC21AAB & $\begin{array}{l}302.5 \mathrm{~kg} \\
5 \mathrm{~kg} \text { PuO }\end{array}$ & & & & $0.8799 \pm 0.0039$ \\
\hline
\end{tabular}

\begin{tabular}{|c|c|c|c|c|c|}
\hline & $\begin{array}{r}\text { Table E } \\
\text { PuO }_{2} \\
\text { Nominal }\end{array}$ & $\begin{array}{r}\mathrm{HC}-21 \\
\text { th } \mathrm{Pu} \\
2.5 \\
\text { flectio }\end{array}$ & $\begin{array}{l}\text { eve Scree } \\
\mathrm{g} / \mathrm{cm}^{3} \text { and } \\
\text { gram Meta } \\
1 \text { Inch }\end{array}$ & $\begin{array}{l}\text { an MONK6B } \\
\text { drogen/239 } \\
\text { suttons } \\
\text { er on Side }\end{array}$ & \\
\hline Case \# & $\begin{array}{l}\text { Pu Metal } \\
\text { in Boats }\end{array}$ & $\begin{array}{l}\text { Sieve } \\
\text { Stack }\end{array}$ & $\begin{array}{l}\mathrm{PuO}_{2} \\
\text { Cans }\end{array}$ & $\begin{array}{l}\mathrm{PuO}_{2} \text { on } \\
\mathrm{GB} \text { floor }^{2}\end{array}$ & $\frac{\text { RESULTS }}{k_{\text {eff }} \pm \sigma}$ \\
\hline \begin{tabular}{|l|} 
HC21AB1 \\
\end{tabular} & & $1.65 \mathrm{~L}$ & & & $0.6899 \pm 0.0030$ \\
\hline \begin{tabular}{|l|} 
HC21AB2 \\
\end{tabular} & & $3.29 \mathrm{~L}$ & & & $0.9584 \pm 0.0033$ \\
\hline \begin{tabular}{|l} 
HC21AB3 \\
\end{tabular} & & $4.94 \mathrm{~L}$ & & & $1.1084 \pm 0.0036$ \\
\hline \begin{tabular}{|l|} 
HC21AB4 \\
\end{tabular} & & $6.59 \mathrm{~L}$ & & & $1.1783 \pm 0.0037$ \\
\hline \begin{tabular}{|l} 
HC21AB55 \\
\end{tabular} & & $1.65 \mathrm{~L}$ & $305 \mathrm{kq}$ & & $0.9170 \pm 0.0033$ \\
\hline HC21AB6 & & $.65 \mathrm{~L}$ & $3 \circlearrowright 5 \mathrm{~kg}$ & $0.125^{\prime \prime}$ & $0.9378 \pm 0.0036$ \\
\hline
\end{tabular}


WHC-SD-SQA-CSA-520 Rev. 0

\begin{tabular}{|c|c|c|c|c|c|}
\hline \multicolumn{6}{|c|}{$\begin{array}{c}\text { Table E. } 3 \text { HC-21A } 4.4 \mathrm{~kg} \text { Pu Cans MONK6B Results. } \\
\mathrm{PuO}_{2} \text { with } \mathrm{Pu} 5.5 \mathrm{~g} / \mathrm{cm}^{3} \text { and Hydrogen } /{ }^{239} \mathrm{Pu}=2 \\
2.5 \mathrm{Kilogram} \text { Metal Buttons } \\
\text { Nominal Reflection is } 1 \text { Inch Water on Sides and Top }\end{array}$} \\
\hline Case \# & $\begin{array}{l}\text { Pu Metal } \\
\text { in Boats }\end{array}$ & $\begin{array}{l}\text { Sieve } \\
\text { Stack }\end{array}$ & $\begin{array}{l}\mathrm{PuO}_{2} \text { in } \\
\text { Cans }\end{array}$ & $\begin{array}{l}\mathrm{PuO}_{2} \text { on } \\
\mathrm{GB} \text { floor }\end{array}$ & $\frac{\text { RESULTS }}{\mathrm{k}_{\text {eff }} \pm \sigma}$ \\
\hline HC21AC1 & & & $305 \mathrm{~kg}$ & & $0.9081 \pm 0.0033$ \\
\hline HC21AC2 & & & $405 \mathrm{~kg}$ & & $0140 \pm 0.0036$ \\
\hline HC21AC3 & & & $505 \mathrm{~kg}$ & & $0512 \pm 0.0035$ \\
\hline HC21AC4 & & & 60 $5 \mathrm{~kg}$ & & $.0887 \pm 0.0035$ \\
\hline HC21AC5 & & & \begin{tabular}{|lll}
70 & $5 \mathrm{~kg}$ \\
\end{tabular} & & $.1319 \pm 0.0035$ \\
\hline HC21AC6 & & & $305 \mathrm{~kg}$ & $0.125^{\prime \prime}$ & $0.9226 \pm 0.0038$ \\
\hline HC21AC7 & & & $405 \mathrm{~kg}$ & $0.125^{\prime \prime}$ & $.0300 \pm 0.003$ \\
\hline HC21AC8 & & & $505 \mathrm{~kg}$ & $0.125^{\prime \prime}$ & $.0712 \pm 0.0038$ \\
\hline HC21AC9 & & & $605 \mathrm{~kg}$ & $0.125^{\prime \prime}$ & $1.1006 \pm 0.0038$ \\
\hline HC21ACA & & & \begin{tabular}{|l|l|}
$7 \mathrm{a} 5 \mathrm{~kg}$ \\
\end{tabular} & $0.125^{\prime \prime}$ & $1.1443+0.0039$ \\
\hline
\end{tabular}


WHC-SD-SQA-CSA-520 Rev. 0

\begin{tabular}{|c|c|c|c|c|c|}
\hline \multicolumn{6}{|c|}{ 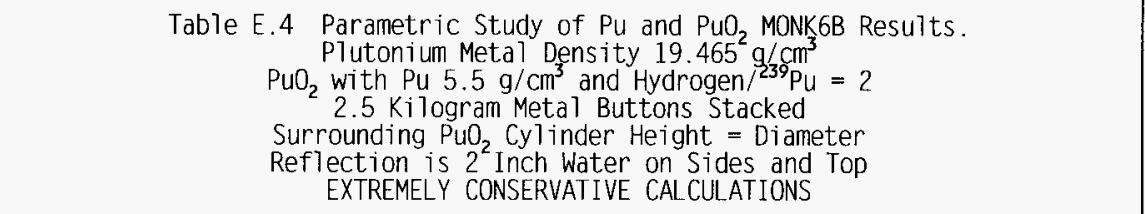 } \\
\hline & $0.0 \mathrm{~kg} \mathrm{Pu}$ & $2.5 \mathrm{~kg} \mathrm{Pu}$ & $5.0 \mathrm{~kg} \mathrm{Pu}$ & $7.5 \mathrm{~kg} \mathrm{Pu}$ & $10.0 \mathrm{~kg} \mathrm{Pu}$ \\
\hline $0.0 \mathrm{~kg} \mathrm{PuO}$ & $0.0000 \pm 0.0000$ & $\begin{array}{r}0.7067 \pm 0.0028 \\
\mathrm{~b} 1 \mathrm{p} 000 \mathrm{n}\end{array}$ & $\begin{array}{r}0.9215 \pm 0.0031 \\
\text { b2p000n }\end{array}$ & $\begin{array}{r}1.0320 \pm 0.0033 \\
\text { b3p000n }\end{array}$ & $\begin{array}{r}1.0970 \pm 0.0035 \\
\mathrm{~b} 4 \mathrm{p} 000 \mathrm{n}\end{array}$ \\
\hline $2.5 \mathrm{~kg} \mathrm{PuO}$ & $\begin{array}{r}0.5441 \pm 0.0024 \\
\text { b0p025n }\end{array}$ & $\begin{array}{r}0.8057 \pm 0.0034 \\
\mathrm{~b} 1 \mathrm{p} 025 \mathrm{n}\end{array}$ & $\begin{array}{r}0.9944 \pm 0.0035 \\
\mathrm{~b} 2 \mathrm{p} 025 \mathrm{n}\end{array}$ & $\begin{array}{r}1.1103 \pm 0.0036 \\
\text { b3p025n }\end{array}$ & $\begin{array}{r}1.1537 \pm 0.0036 \\
\mathrm{~b} 4 \mathrm{p} 025 \mathrm{n}\end{array}$ \\
\hline $5.0 \mathrm{~kg} \mathrm{PuO}$ & $\begin{array}{r}0.6916 \pm 0.0029 \\
\mathrm{~b} 0 \mathrm{p} 050 \mathrm{n}\end{array}$ & $\begin{array}{r}0.8624 \pm 0.0034 \\
\mathrm{~b} 1 \mathrm{p} 050 \mathrm{n}\end{array}$ & $\begin{array}{r}1.0303 \pm 0.0037 \\
\text { b2p050n }\end{array}$ & $\begin{array}{r}1.1392 \pm 0.0039 \\
\mathrm{~b} 3 \mathrm{p} 050 \mathrm{n}\end{array}$ & $\begin{array}{r}1.2018 \pm 0.0038 \\
b 4 p 050 n\end{array}$ \\
\hline $7.5 \mathrm{~kg} \mathrm{PuO}$ & $\begin{array}{r}0.7790 \pm 0.0029 \\
\text { b0p075n }\end{array}$ & $\begin{array}{r}0.9134 \pm 0.0033 \\
\text { b1p075n } \\
\end{array}$ & $\begin{array}{r}1.0577 \pm 0.0037 \\
\mathrm{~b} 2 \mathrm{p} 075 \mathrm{n}\end{array}$ & $\begin{array}{r}1.1728 \pm 0.0040 \\
\mathrm{~b} 3 \mathrm{p} 075 \mathrm{n}\end{array}$ & $\begin{array}{r}1.2297 \pm 0.0039 \\
\mathrm{~b} 4 \mathrm{p} 075 \mathrm{n}\end{array}$ \\
\hline $10.0 \mathrm{~kg} \mathrm{PuO}$ & $\begin{array}{r}0.8461 \pm 0.0030 \\
\text { b0p } 100 \mathrm{n}\end{array}$ & $\begin{array}{r}0.9510 \pm 0.0034 \\
\text { blp } 100 \mathrm{n}\end{array}$ & $\begin{array}{r}1.0816 \pm 0.0040 \\
\mathrm{~b} 2 \mathrm{p} 100 \mathrm{n}\end{array}$ & $\begin{array}{r}1.2052 \pm 0.0039 \\
\mathrm{~b} 3 \mathrm{p} 100 \mathrm{n}\end{array}$ & \\
\hline $12.5 \mathrm{~kg} \mathrm{PuO}$ & $\begin{array}{r}0.9050 \pm 0.0032 \\
\text { b0p125n } \\
\end{array}$ & $\begin{array}{r}0.9855 \pm 0.0036 \\
\text { b1p125n }\end{array}$ & $\begin{array}{r}1.1041 \pm 0.0037 \\
\text { b2p125n }\end{array}$ & & \\
\hline $15.0 \mathrm{~kg} \mathrm{PuO}$ & $\begin{array}{r}0.9566 \pm 0.0033 \\
\text { b0p150n }\end{array}$ & $\begin{array}{r}1.0179 \pm 0.0036 \\
\text { blp150n }\end{array}$ & & & \\
\hline $17.5 \mathrm{~kg} \mathrm{PuO}$ & $\begin{array}{r}0.9925 \pm 0.0034 \\
\mathrm{~b} 0 \mathrm{p} 175 \mathrm{n}\end{array}$ & $\begin{array}{r}1.0521 \pm 0.0035 \\
\text { blp175n }\end{array}$ & & & \\
\hline $20.0 \mathrm{~kg} \mathrm{PuO}$ & $\begin{array}{r}1.0290 \pm 0.0035 \\
\text { b0p200n }\end{array}$ & & & & \\
\hline
\end{tabular}




\section{DISTRIBUTION SHEET}

\begin{tabular}{|c|c|c|c|c|c|}
\hline \multirow{2}{*}{$\begin{array}{l}\text { To } \\
\text { Distribution }\end{array}$} & \multirow{2}{*}{\multicolumn{3}{|c|}{$\begin{array}{l}\text { From } \\
\text { Criticality and Shielding }\end{array}$}} & \multicolumn{2}{|l|}{ Page 1 of 1} \\
\hline & & & & \multicolumn{2}{|c|}{ Date $11 / 19 / 96$} \\
\hline \multirow{2}{*}{\multicolumn{4}{|c|}{$\begin{array}{l}\text { Project Title/Work Order } \\
\text { CSER } 96-023 \text { : CSER for PFP Glovebox HC-21A with } 4.4 \text { Kilogram } \\
\text { Plutoni um Cans }\end{array}$}} & \multirow{2}{*}{\multicolumn{2}{|c|}{$\begin{array}{ll}\text { EDT No. } & 619222 \\
\text { ECN No. } & \text { N/A } \\
\end{array}$}} \\
\hline & & & & & \\
\hline Name & MSIN & $\begin{array}{l}\text { Text } \\
\text { With All } \\
\text { Attach. }\end{array}$ & Text Only & \begin{tabular}{|c} 
Attach./ \\
Appendix \\
Only \\
\end{tabular} & $\begin{array}{l}\text { EDT/ECN } \\
\text { Only }\end{array}$ \\
\hline $\begin{array}{l}\text { S.J. Altschuler } \\
\text { E.P. Bonadie } \\
\text { K.D. Dobbin } \\
\text { D.G. Erickson } \\
\text { S.R. Gedeon } \\
\text { M.W. Gibson } \\
\text { J. Greenborg } \\
\text { K.E. Hilles1and } \\
\text { S.F. Kessler } \\
\text { C.M. Kronva11 } \\
\text { J.S. Lan } \\
\text { W.S. Lewis } \\
\text { E.M. Miller } \\
\text { L.T. Nirider } \\
\text { S.E. Nunn } \\
\text { L.L. Pedersen (3) } \\
\text { R.F. Richards } \\
\text { S.P. Roblyer } \\
\text { L.H. Rodgers } \\
\text { R.H. Ruben } \\
\text { K.N. Schwinkendorf } \\
\text { S.S. Tsai } \\
\text { W.D. Wittekind (2) } \\
\text { W.T. Watson } \\
\text { Central Files }\end{array}$ & 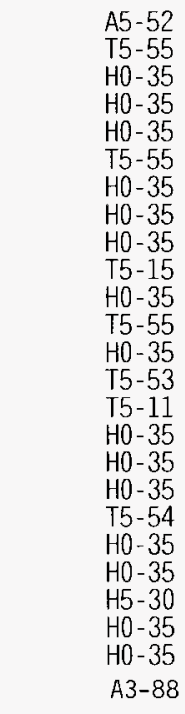 & $\begin{array}{l}x \\
x \\
x \\
x \\
x \\
x \\
x \\
x \\
x \\
x \\
x \\
x \\
x \\
x \\
x \\
x \\
x \\
x \\
x \\
x \\
x \\
x \\
x \\
x \\
x \\
x\end{array}$ & & & \\
\hline
\end{tabular}

